University of Rhode Island

DigitalCommons@URI

Open Access Master's Theses

2017

\title{
Assessing Hydrology, Carbon Flux, and Soil Spatial Variability Within Vernal Pool Wetlands
}

Bianca N. Ross

University of Rhode Island, bnross44@gmail.com

Follow this and additional works at: https://digitalcommons.uri.edu/theses

\section{Recommended Citation}

Ross, Bianca N., "Assessing Hydrology, Carbon Flux, and Soil Spatial Variability Within Vernal Pool Wetlands" (2017). Open Access Master's Theses. Paper 1014.

https://digitalcommons.uri.edu/theses/1014

This Thesis is brought to you for free and open access by DigitalCommons@URI. It has been accepted for inclusion in Open Access Master's Theses by an authorized administrator of DigitalCommons@URI. For more information, please contact digitalcommons-group@uri.edu. 
ASSESSING HYDROLOGY, CARBON FLUX, AND SOIL

SPATIAL VARIABILITY WITHIN VERNAL POOL

WETLANDS

BY

BIANCA N. ROSS

A THESIS SUBMITTED IN PARTIAL FULFILLMENT OF THE

REQUIREMENTS FOR THE DEGREE OF

MASTER OF SCIENCE

IN

BIOLOGICAL AND ENVIRONMENTAL SCIENCES

UNIVERSITY OF RHODE ISLAND

2017 
MASTER OF SCIENCE THESIS

OF

BIANCA N. ROSS

\section{APPROVED:}

Thesis Committee:

$\begin{array}{ll}\text { Major Professor } & \text { Mark Stolt } \\ \text { Jose Amador } & \text { Cathleen Wigand }\end{array}$

Nasser H. Zawia DEAN OF THE GRADUATE SCHOOL

UNIVERSITY OF RHODE ISLAND

2017 


\begin{abstract}
Vernal pools are small isolated wetlands that are covered by shallow water for variable periods in the winter and spring but may be completely dry for most of the summer and fall. Despite their small size, vernal pools are a dominant wetland type throughout New England. These wetlands are hotspots of floral and faunal biodiversity, as their unique hydrology and landscape characteristics allow them to serve as a home and breeding ground for many distinct plant and animal species. Because of their abundance in New England, vernal pools may also be an important long-term regional storehouse for organic carbon. Despite the functional and ecological values of vernal pools, few studies have investigated how variations in hydrology, pool size, geomorphic setting, and surrounding landscape attributes affect soil carbon in these systems and the associated hydric soils that sequester the carbon. Therefore, the primary objectives of this thesis were to i) assess the effect of landscape characteristics on hydrologic and edaphic conditions; ii) investigate the need for additional hydric soil indicators for vernal pool soils; iii) quantify the relationship between vernal pool hydrology and greenhouse gas fluxes; and iv) evaluate processes of carbon cycling throughout vernal pools.
\end{abstract}

Twenty-one vernal pools in southern Rhode Island were selected and their landscape attributes were characterized using spatial tools in GIS. Sixteen of the 21 pools formed in glaciofluvial deposits on outwash plains, kame terraces, and moraines. The rest formed in till or alluvial landscapes. Vernal pool basin areas ranged from 6 to $381 \mathrm{~m}^{2}$ and mean slopes of the adjacent landscape ranged from 3 to $20 \%$. Slope class was not significantly correlated to basin area $\left(\mathrm{R}^{2}=0.03\right)$. Four vernal pools were 
selected for detailed studies of hydrology, soils, and vegetation in the basin, transition, and upland zones. Water table levels were monitored in each hydrologic zone from June 2015 to October 2016. Median water table levels increased in depth from the soil surface with increased distance from the vernal pool basin. Basin zones were consecutively inundated for the longest period of time, followed by transitional zones; upland zones were never inundated. Water table gradients indicated discharge into pool basins for the majority of the year. Vernal pools with steep slopes showed recharge gradients during periods of significant inundation suggesting a relationship between slope class and hydrology. Vernal pool soils classified as Spodosols, Inceptisols, and Histosols. Although all of the basin and transitional zones met the saturation requirements for hydric soils, $25 \%$ of the soils did not meet a hydric soil indicator. Both of these soils were Spodosols, suggesting the need for continued evaluation of hydric soils with spodic morphologies. Twenty-one plant species were identified across all study sites. Specifically, basin zones were dominated by obligate wetland plants, while transitional and upland zones consisted primarily of facultative and facultative wetland plants. Analysis allowed for the identification of plant species that accurately reflected the hydrologic nature of each zone, which affirmed the relationship between vegetation and hydrology.

Carbon pools and the contributions to the wetland soil carbon cycle, including leaf litter additions, decomposition of coarse woody debris and leaves, and $\mathrm{CO}_{2}$ from respiration, were monitored during the majority of two growing seasons. On average, basin and transitional zone soils possessed the largest soil organic carbon (SOC) pools $\left(11 \mathrm{~kg} \mathrm{~m}^{-2}\right)$, while SOC pools in upland zones were substantially less $\left(8 \mathrm{~kg} \mathrm{~m}^{-2}\right)$. Leaf 
litter additions ranged from 40 to $149 \mathrm{~g} \mathrm{C} \mathrm{m}^{-2}$ depending on the site and hydrologic zone. Leaf litter bags and wooden dowel rods (representing coarse woody debris) were placed at the surface of each zone in order to investigate above-ground decomposition. Dowel rods were also inserted vertically into the soil to $25 \mathrm{~cm}$ in 2015 to investigate below-ground decomposition. On average, basin zones experienced the highest leaf litter loss (12 $\left.\mathrm{g} \mathrm{C} \mathrm{m}^{-2} ; 18 \%\right)$, while upland zones experienced the lowest loss $\left(6 \mathrm{~g} \mathrm{C} \mathrm{m}^{-2} ; 10 \%\right)$. Basin zones also exhibited the highest mean surface dowel loss in 2015 (4\%). Losses from 2016 followed similar trends, but lower precipitation experienced by the pools resulted in significantly lower losses. On average, the highest below-ground decomposition occurred in the upland zone (16\%). Analysis comparing vernal pool hydrology to organic matter decomposition yielded results that trended toward significance in 2015 for leaf litter $(\mathrm{p}=0.06)$ and ground dowels losses $(\mathrm{p}=0.07)$. Above-ground decomposition decreased as the water table receded further from the soil surface; conversely, below-ground decomposition increased as the water table receded further from the surface. Carbon dioxide $\left(\mathrm{CO}_{2}\right)$, methane $\left(\mathrm{CH}_{4}\right)$, and nitrous oxide $\left(\mathrm{N}_{2} \mathrm{O}\right)$ fluxes were measured between the months of August and November in 2015, and between May and August in 2016. $\mathrm{CO}_{2}$ flux was significantly correlated with soil temperature $(\mathrm{p}<0.001)$ and hydrologic zone across all study sites $(p=0.03)$. Flux increased as soil temperature increased and as the depth between the soil surface and the water table increased. Although the partitioning of heterotrophic and autotrophic respiration yielded weak correlations $\left(\mathrm{R}^{2}<0.5\right)$, analysis suggested that root respiration accounted for $<40 \%$ of the total $\mathrm{CO}_{2}$ flux. Mean monthly $\mathrm{CO}_{2}$ fluxes were highest in the transitional zones, ranging from 5 to $22 \mu$ mole $\mathrm{m}^{-2} \mathrm{~min}^{-1}$ 
across all zones. $\mathrm{CH}_{4}$ flux was significantly correlated with vernal pool hydrology in all study sites $(\mathrm{p}<0.003)$. Positive emissions ranged from 0.02 to $0.03 \mu$ mole $\mathrm{m}^{-2}$ $\min ^{-1}$ and only occurred in the basin zones during the months of May and June, when the basins were inundated with surface water. Transitional and upland zones exhibited net $\mathrm{CH}_{4}$ absorption, as did the basin zones during months other than May and June. Nitrous oxide fluxes ranged from -0.009 to $0.008 \mu$ mole $\mathrm{m}^{-2} \mathrm{~min}^{-1}$ and did not vary significantly with hydrologic zone. Despite their small size and ephemeral nature, their significant contribution to greenhouse gas efflux and removal from the atmosphere warrant future investigations and conservation of vernal pools. 


\section{ACKNOWLEDGMENTS}

I would like to thank my major professor Dr. Mark Stolt for providing me with this amazing research opportunity that allowed me to spend every day pursuing my passion for soils, and for your continued guidance and support throughout my entire academic career. I would also like to thank my committee members, Dr. Jose Amador and Dr. Cathleen Wigand for all of the help and broadened perspectives that you have shared with me.

Additionally, I offer my sincere thanks to my Coastal Fellows, student volunteers, and everyone in the Laboratory of Pedology and Soil Environmental Science for your assistance both in the field and in the lab. I would like to also acknowledge Nancy Karraker, Peter August, Dennis Skidds, Jim Turenne, and all members participating in the multistate project NE-1438 for sharing your knowledge and expertise with me.

Special thanks go to my friends and family for your love and words of encouragement throughout every stage of this study. Finally, I would like to thank my husband Drew, whose limitless support, love, and belief in me helped make all of this possible.

This research was funded by the Rhode Island Agricultural Experiment Station and the multistate project NE-1438. 


\section{PREFACE}

This thesis was written and formatted following the guidelines presented by the University of Rhode Island Graduate School. There are two chapters: Vernal Pool

Traits and Morphology (Chapter 1) and Hydrological Impacts on Vernal Pool Gas Flux and Carbon Storage (Chapter 2). 


\section{TABLE OF CONTENTS}

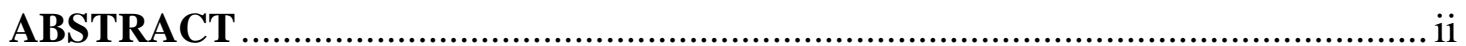

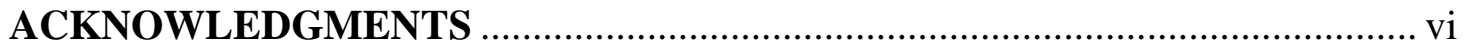

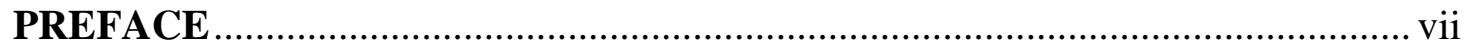

TABLE OF CONTENTS ....................................................................... viii

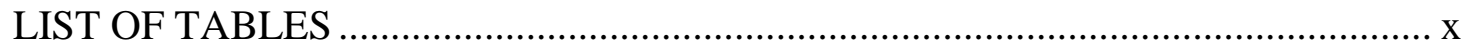

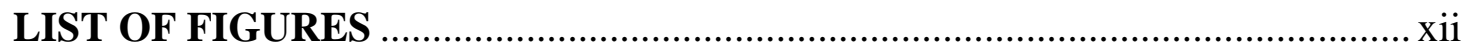

CHAPTER 1: VERNAL POOL TRAITS AND MORHPOLOGY ...................... 1

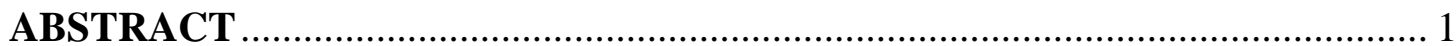

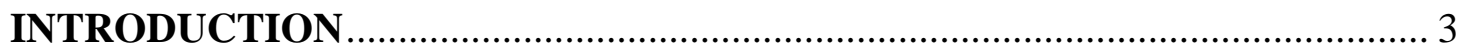

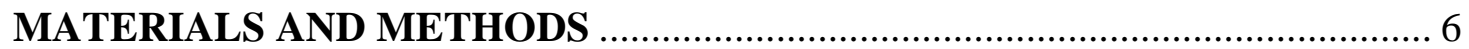

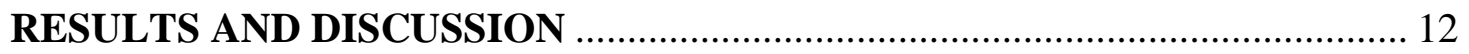

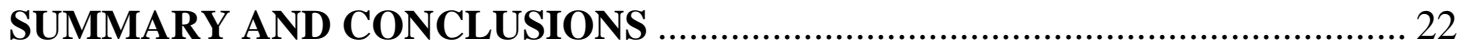

CHAPTER 2: HYDROLOGICAL IMPLICATIONS ON VERNAL POOL GAS

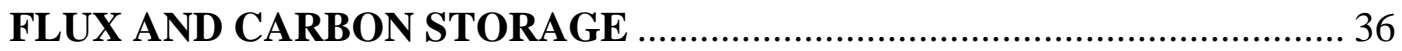

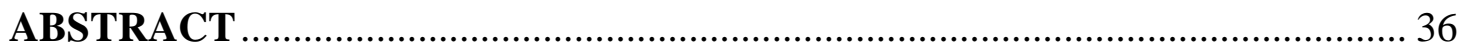

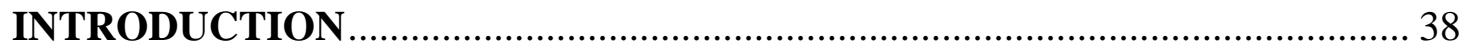

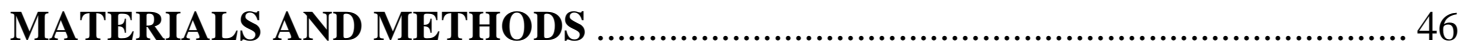

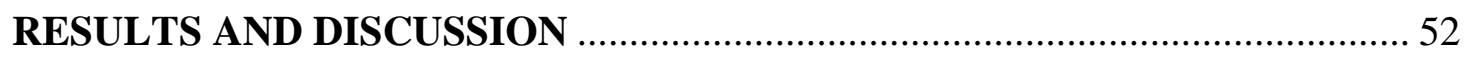

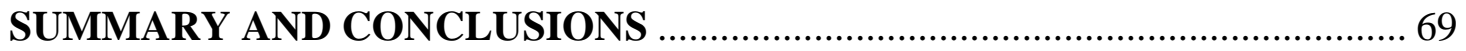

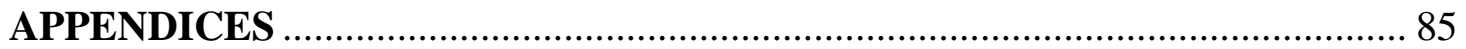

APPENDIX 1. Experimental design of vernal pools........................................... 85 
APPENDIX 2. Odyssey logger measurements for each vernal pool over the course of this study. 86

APPENDIX 3. Average monthly temperatures during 2015 and 2016 as compared to

30-year averages. 88

APPENDIX 4. Hydraulic gradients of main and supplementary transects at each vernal pool. 89

APPENDIX 5. Morphological descriptions of the soils at each vernal pool. 93

APPENDIX 6. An analysis of the absolute percent cover of dominant vegetation in each vernal pool. 96

APPENDIX 7. Soil morphological descriptions of $50 \mathrm{~cm}$ cores. 97

APPENDIX 8. Soil data obtained from $50 \mathrm{~cm}$ cores (bulk density and LOI) 104

BIBLIOGRAPHY 107 


\section{LIST OF TABLES}

TABLE

PAGE

Table 1.1. Site characteristics of a subset of 21 vernal pools in southern Rhode Island

Table 1.2. Summary of water table measurements made by Odyssey loggers at each

study site 25

Table 1.3. Consecutive period of time during which the water table was above established benchmarks during the growing season 26

Table 1.4. Cumulative period of time during which the water table was above established benchmarks during the growing season 26

Table 1.5. Taxonomic classifications and hydric soil indicators assigned to soils sampled from all hydrologic zones .....

Table 1.6. Morphological descriptions of common soil types found throughout the vernal pools and an associated glossary of abbreviations 28

Table 1.7. Plant species dominating each hydrologic zone during the summer of 2016

Table 2.1. Total SOC pools in the upper $50 \mathrm{~cm}$ of each hydrologic zone across all study sites 72

Table 2.2. Regression analysis of organic matter decomposition compared to the water table during the 2015 and 2016 field seasons 73

Table 2.3. Summaries of a single regression analysis comparing soil temperature and soil respiration ("Single") and a multiple regression analysis comparing soil temperature, water table level, and soil respiration ("Multiple") 74 
Table 2.4. Non-parametric one-way ANOVA analysis of hydrologic zone vs. $\mathrm{CO}_{2}$ flux

Table 2.5. Regression analysis comparing root density and soil respiration during the

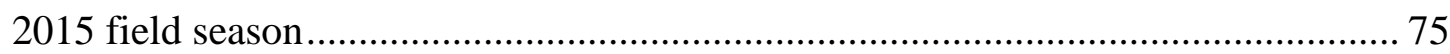

Table 2.6. Estimated percentage of mean root respiration out of total soil respiration

Table 2.7. Non-parametric one-way ANOVA analysis of hydrologic zone vs. percent

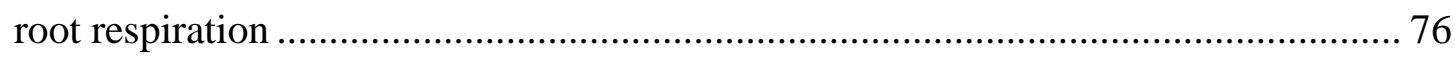

Table 2.8. Regression analysis comparing $\mathrm{CH}_{4}$ flux to water table level.................. 77

Table 2.9. One-way ANOVA analysis of hydrologic zone vs. $\mathrm{CH}_{4}$ flux.............77 


\section{LIST OF FIGURES}

FIGURE

PAGE

Figure 1.1. Odyssey logger measurements for Great Swamp over the course of the

study.

Figure 1.2. Regression analysis of average water table levels compared to average

monthly temperatures. 32

Figure 1.3. A representation of the water table gradient in the vernal pools 33

Figure 1.4. Local monthly precipitation for 2015 and 2016, as compared to the range of normal field conditions 34

Figure 1.5. An analysis of the absolute percent cover of dominant vegetation in each vernal pool 35

Figure 2.1. Proportion of the total SOC $\left(\mathrm{kg} \mathrm{C} \mathrm{m}^{-2}\right)$ stored in the master horizons of soils from each hydrologic zone 78

Figure 2.2. Mean SOC additions and mean SOC losses in the three hydrologic zones at each vernal pool 79

Figure 2.3. Mean leaf litter decomposition in the three hydrologic zones at each vernal pool during the 2015 and 2016 field seasons 80

Figure 2.4. Total monthly precipitation during 2015 and 2016, compared to monthly

30-year averages. 80

Figure 2.5. Mean surface dowel decomposition in the three hydrologic zones at each vernal pool during the 2015 and 2016 field seasons 81 
Figure 2.6. Mean ground dowel decomposition in the three hydrologic zones at each vernal pool during the 2015 and 2016 field seasons

Figure 2.7. Regression analysis of $\mathrm{CO}_{2}$ flux compared to the water table level across

all sampling months and hydrologic zones at Eppley and Great Swamp .................. 82

Figure 2.8. Monthly $\mathrm{CO}_{2}$ flux compared to soil hydrology ................................. 83

Figure 2.9. Mean monthly $\mathrm{CO}_{2}$ fluxes across all vernal pools ............................. 83

Figure 2.10. Mean monthly $\mathrm{CH}_{4}$ fluxes across all vernal pools.............................. 84

Figure 2.11. Mean monthly $\mathrm{N}_{2} \mathrm{O}$ fluxes across all vernal pools....................84 


\title{
CHAPTER 1: VERNAL POOL TRAITS AND MORHPOLOGY
}

\begin{abstract}
Vernal pools are small isolated wetlands $\left(<1000 \mathrm{~m}^{2}\right)$ with variable ponding throughout the seasons. Their unique hydrology and landscape characteristics make them one of the most ecologically valuable wetland types. Although vernal pools have been widely studied, few studies have evaluated the effect of landscape setting and attributes on hydrologic and edaphic conditions. In this study, landscape attributes were examined for 21 vernal pools in southern New England. These wetlands formed in till, outwash, and alluvial landscapes on drumlins, floodplains, outwash plains, kame terraces, and moraines. I used 1-m resolution LIDAR data analyzed with a digital elevation model to determine the basin size (wetland area) and adjacent slope of each vernal pool. Vernal pool basin areas were $<1000 \mathrm{~m}^{2}$, ranging from 6 to $381 \mathrm{~m}^{2}$. Mean slopes of the land surrounding the vernal pool basins ranged from 3 to $20 \%$ and were not significantly correlated to basin size $\left(\mathrm{R}^{2}=0.03\right)$. Four vernal pools were selected for detailed studies of hydrology, soils, and vegetation in the basin, transition, and upland zones. Water table levels were monitored from June 2015 to October 2016. Median water table levels ranged from 7 to $32 \mathrm{~cm}$ in the basin, 36 to $89 \mathrm{~cm}$ in the transitional zones, and 108 to $145 \mathrm{~cm}$ in the uplands. All of the basin and transitional zones were inundated for parts of the two growing seasons of the study. Hydraulic gradients of each pool suggested discharge conditions for most of the year, however, pools with steep slopes showed a reversal in the hydraulic gradients during significant inundation suggesting a relationship between slope and
\end{abstract}


hydrology. Vernal pool soils were classified as Spodosols, Inceptisols, and Histosols. Although all of basin and transition soils met the saturation criteria necessary to be considered hydric soils, two of the eight soils (both Spodosols) did not meet any current hydric soil indicator suggesting a need for continued investigation of hydric soils with spodic morphologies. Twenty-one plant species were identified across the three zones. Obligate wetland plants in the form of herbaceous vegetation dominated basin zones, while transitional and upland zones consisted primarily of facultative and facultative wetland vegetation (shrubs). The only basin zone that exhibited any nonherbaceous vegetation also experienced a shorter hydroperiod in comparison to the other pools. The plant species identified accurately reflected the hydrologic nature of each zone, thus affirming the relationship between vegetation and hydrology. 


\section{INTRODUCTION}

Vernal pools are small isolated wetlands covered by shallow water for variable periods in the winter and spring, but may be completely dry for most of the summer and fall (Calhoun and deMaynadier, 2004; Skidds and Golet, 2005). Vernal pools form in many different geomorphic settings, including kettle holes, oxbow scars, and Carolina and Delmarva Bays (Brooks, 2005; Leibowitz, 2003). In New England, these wetlands primarily form in till and outwash on drumlins, outwash plains, and moraines as depressions are created during glaciation and subsequent deglaciation (Tiner, 2003; Skidds and Golet, 2005). They can also form on alluvial landscapes, such as floodplains, as stream and river waters overflow and cut into the surrounding landscape, creating pockets in the land where water may accumulate (Tiner, 2003). Although some have been found to be upwards of 0.3 ha in size, most New England vernal pools are less than 0.1 ha in size (Brooks and Hayashi, 2002; Skidds and Golet, 2005; Rheinhart et al., 2007; Capps et al., 2014). At the scale that current Soil Survey and National Wetland Inventory maps were created, vernal pools are often missed because of their small size (Witham et al., 1998).

Vernal pools are hotspots of floral and faunal biodiversity, serving as a home and breeding ground for not only unique animal species, but also unique plant species. For example, one study identified more than 400 different plant species that inhabit vernal pools in the northeastern United States, 20 of which are at risk of extinction in New England (Cutko and Rawinski, 2008). The fact that a large number of the floral and faunal species inhabiting vernal pools are endemic and/or endangered suggests that even small amounts of cumulative vernal pool destruction could lead to local and 
regional extirpations (Leibowitz, 2003). Despite the ecological value of vernal pools in New England, few studies have investigated how variations in pool size, geomorphic setting, surrounding landscape attributes (slope class), and hydrology affect the associated soils in these systems.

Hydrologic patterns and variations are two of the primary driving factors in the distribution and success of vernal pool species. Many different hydrologic and edaphic factors determine the nature of vernal pool hydrology. For example, vernal pool geomorphology, soils, surficial geology, and landscape position impacts the hydrologic inputs and outputs exhibited by vernal pools (Smith et al, 1995; Leibowitz, 2003). Studies have observed a positive correlation between basin area and the span of time vernal pool basins are inundated with water, often referred to as hydroperiod (Brooks and Hayashi, 2002; Skidds and Golet, 2005). Other studies have observed that hydroperiod length can be linked to morphological characteristics of basin soils, such as soil texture and permeability (Calhoun et al., 2013). This suggests the possibility of a relationship between basin size and soil morphology, while also raising the question of whether one characteristic has a greater impact on vernal pool hydrology than the other. Most studies of vernal pools have focused on the length of inundation because of the impact of this hydrologic parameter on amphibians. Thus, few studies have included other aspects of hydrology, such as groundwater levels and dynamics and there has been little investigation into the relationship between different landforms and the subsurface hydrology of their corresponding vernal pools.

By definition, hydric soils are soils "that formed under conditions of saturation, flooding, or ponding long enough during the growing season to develop anaerobic 
conditions in the upper part" (USDA-NRCS, 2016). Both ponding and saturation occur in the basins of vernal pools providing hydrologic evidence for the presence of hydric soils in these systems. Hydrology is rarely used to identify hydric soils because of seasonal and yearly variations due to climate and similar factors. Instead, field indicators have been developed in order to identify hydric soils through soil morphology (USDA-NRCS, 2016). These indicators are region-specific, and were developed in order to assist with wetland delineation (U.S. Army Corps of Engineers, 2012), and with planning for land-use and conservation purposes. However, because of the unique nature of vernal pool wetlands, scientists have questioned whether these indicators are too broad to successfully encompass all wetland types, or if new indicators should be developed for vernal pools (USDA-NRCS, 2016).

The goal of this study was to analyze morphological and hydrological characteristics of selected vernal pool wetlands in Southern Rhode Island. This study was one of a subset of studies of vernal pool soils and hydrology across the northeast. Few detailed studies have simultaneously compared variations in hydrology and related soil morphologies and properties across the region. Studies on a regional level will allow for the creation of a catalogue of the different morphologies, vegetation, and geomorphic surfaces and landforms that are found throughout the northeastern United States. Documenting the differences in vernal pool ecosystems will enable researchers to test hypotheses across varying climates, soil parent materials, and landscape settings (Smith et al., 1995; Lebowitz, 2003; Skidds and Golet, 2005). Specifically, I investigated the relationship between variations in the landscape attributes of vernal pools and their morphological and hydrological features in the 
Pawcatuck River Watershed. By initially conducting a broad study of vernal pools within the watershed, I was able to select several pools to study that are representative of common Southern Rhode Island vernal pool characteristics. Focusing on a small subsample of vernal pools allowed for a detailed analysis of specific traits, including landscape characteristics, vegetation distribution, soil morphology, and hydrology.

\section{MATERIALS AND METHODS}

\section{$\underline{\text { Site Selection }}$}

In initial studies, 65 vernal pools that Skidds and Golet (2005) investigated in the Pawcatuck River Watershed, Rhode Island were evaluated for possible detailed studies. These sites aligned with the breadth of landscape settings and soil parent materials that occur in southern Rhode Island including those adjacent to streams and rivers (alluvial), on outwash plains and kame terraces (glaciofluvial outwash or icecontact materials), and on drumlins and upland settings (lodgement and ablation till) (Skidds and Golet, 2005). Only those vernal pools with hydroperiods that lie within two weeks of the average hydroperiod of these 65 pools were considered for investigation. In addition, field investigations were paired with satellite imagery analysis in order to identify five other potential vernal pools that Skidds and Golet (2005) did not study in the Pawcatuck River watershed. I reviewed the RIGIS 1939 Digital Aerial Orthophoto data to ensure that the sites in consideration had minimal influence from anthropogenic activities (RIGIS, 2002) and utilized the 2014 Rhode Island Soil Survey data to identify the parent materials located at each of the sites (RIGIS, 2014). Soils formed in till are difficult to investigate with hand tools such as 
an auger or to instrument with wells, thus, final field sites were biased toward vernal pools located on soils formed in glaciofluvial deposits. Following these spatial analyses, 21 vernal pools were chosen and visited in the fall of 2014 in order to further investigate their relevant soil and landscape attributes, including soil textures and coarse fragment percentages, slopes of the surrounding land leading into each pool, and density of vegetation throughout the basin.

\section{$\underline{\text { GIS Analysis }}$}

Through utilization of the ArcMap 10.3.1 GIS software and current satellite imagery, calculations were made documenting physical characteristics of the 21 vernal pools. Polygon shapefiles were created for each pool selected for this study. Vernal pool basin area was calculated through the use of the "calculate geometry" command in ArcGIS (ESRI, 2011). Furthermore, 1-m resolution LIDAR data analyzed with a digital elevation model were used to determine the adjacent slopes of each vernal pool. A polyline shapefile was created outlining the basin of each vernal pool, around which a buffer was created in order to only highlight the transitional zone, or the zone located between the upland area and vernal pool basin, at each site. Individual buffer sizes were selected through use of the "measure" command in ArcGIS and based on the average sizes of the transitional zone at each vernal pool. This resulted in a successful approximation and isolation of the transitional zone in the study sites, allowing for slope calculations to be made specifically for this zone (RIGIS, 2011). Overlay of the 2014 Rhode Island Soil Survey data, as well as the LIDAR 10-ft contour line dataset, allowed for a characterization of the various landforms and soil parent materials in which the selected vernal pools are found (RIGIS, 2014). 


\section{$\underline{\text { Plot Layout and Experimental Design }}$}

From the 21 vernal pools analyzed, four representative vernal pools were selected for field experimentation, monitoring, and sampling. Three hydrologic zones were defined and identified in each vernal pool site, based on the predominant edaphic, hydrologic, and botanical characteristics of the wetland. The area of the wetland that is seasonally ponded in the winter and early spring, and dries sometime before summer, was considered Zone 1 (basin zone). Hydric soils, as well as shrub, emergent, and/or woody vegetation were present in the basin zone. Zone 2 was the transitional area of the wetland that contains saturated soils, and may exhibit ponding for variable portions of the year (transitional zone). Shrub, emergent, and/or woody vegetation and hydric soils were also present in the transitional zone. The upland area surrounding the vernal pool comprised Zone 3 (upland zone). The upland zone exhibited moderate amounts of wetland vegetation; however, no hydric soils were present.

Three transects were established at each of the four vernal pools. Each transect extended radially outwards from the center of the basin to the upland zone. Transect locations were determined randomly based on compass orientation. On each transect, three research plots were established, one in each hydrologic zone, resulting in a total of nine research plots per site. Zones and transect locations follow the guidelines of the regional multistate project (NE-1438) this study supports.

\section{$\underline{\text { Soil Morphological Descriptions }}$}

At each site, a soil description to the depth of at least $1 \mathrm{~m}$ was made in each zone (Schoeneberger et al., 2012). Samples collected with a bucket auger were 
utilized in order to describe soil horizons, texture, color, and presence of redoximorphic features in the field. Soil descriptions were analyzed and compared to the field indicators of hydric soils that are currently in use in order to consider whether new indicators should be developed for vernal pools (USDA-NRCS, 2016). $\underline{\text { Vegetation Analysis }}$

Vegetation present by zone was identified and analyzed in accordance with the 1987 USACOE Wetland Delineation Manual's regional supplement for the northcentral and northeastern region (U.S. Army Corps of Engineers, 2012). Documented vegetation was divided into four strata: tree, sapling/shrub, herb, and woody vines. One $30-\mathrm{ft}$ circular radius plot was established at each site in the basin and upland zones, and absolute percent cover of vegetation versus bare soil in each of the four strata was documented. Due to the irregular shape of the transitional zone, absolute percent cover was estimated across the entire zone. Measurements were obtained in July 2016.

\section{Climate Data}

Weather data from the University of Rhode Island's long-term monitoring (at least 30 years) weather station (Kingston, RI) were obtained in order to learn of local air temperatures maximums and minimums and daily precipitation (Diamond et al., 2013). One HOBO temperature logger was buried $30 \mathrm{~cm}$ under the soil surface at Great Swamp and measured soil temperature every 4 hours. These data were used in order to identify the growing season, which is defined as the period of time during which soil microorganisms are active. The time period during which soil temperature was consecutively higher than the benchmark of $41^{\circ} \mathrm{F}$ is considered to be the growing 
season for the vernal pool (Ford, 2014). Due to the close proximity of the study sites, I applied growing season established at Great Swamp to all other study sites.

\section{$\underline{\text { Hydrological Measurements }}$}

At each site, the depth of ponded water or the depth to the water table was monitored and recorded, depending on the hydrologic zone and corresponding inundation/saturation patterns. The depth of ponded water within each vernal pool was measured monthly with a staff gauge. Utilizing staff gauges allowed for extrapolation about hydroperiod length of each pool. Staff gauges supplemented data provided by the Odyssey loggers in the basin zones when surface inundation surpassed the extent of the logger (Witham et al., 1998). A PVC monitoring port comprised of a well screen was installed at each plot in the transitional and upland zones to a depth of approximately $100 \mathrm{~cm}$, allowing water tables to be measured periodically. Wells remained in the vernal pools for the duration of this field study, between June 2015 and August 2015. Only one well was installed in the basin zone and was positioned along the central transect. Odyssey loggers were calibrated and installed in wells along one transect at each site in order to record capacitance water level every 6 hours each day. Due to an inability to assess the exact depths of water tables when they surpassed the depth of the loggers, an analysis of the median depth values were used to assess hydrologic trends (Larson and Runyan, 2009; Rabenhorst, 2014). These measurements were extended to other transects depending on the trends exhibited by their monitoring ports. The maximum logger measurement was recorded when the water table depth exceeded the length of the logger. In addition, manual water table measurements were taken monthly at each well on all three transects. In order to 
obtain these manual measurements, a digital voltmeter was connected to 18-gauge speaker wire and the wire was then dropped into the wells. Once the wire touched the water, the electrical circuit was completed and a measurement appeared on the voltmeter. Measuring the depth at which the speaker wire reached the water allowed for a determination of water table depth throughout the various hydrological zones (Marti, 2016).

Certain saturation and precipitation conditions need to be met in order for a soil to meet hydric conditions. Precipitation needs to fall within a certain range of normal field conditions (namely, values that fall between the $30^{\text {th }}$ and $70^{\text {th }}$ percentiles). Thirty-year average precipitation totals and $30^{\text {th }} / 70^{\text {th }}$ percentile values were obtained from the nearest WETS station (Kingston, RI4266) and compared to monthly precipitation totals obtained for this study. Saturation conditions require that the water table reside within $25 \mathrm{~cm}$ of the soil surface for at least 14 consecutive days during the growing season (NTCHS, 2007). Odyssey logger measurements allowed for these conditions to be evaluated at each zone along the main transect.

\section{$\underline{\text { Elevation Measurements }}$}

Elevation measurements were made along each transect using a laser level. Initial benchmark measurements were made at the lowest point of each of the three transects, and additional measurements were made at each well. Measurements were also made every 10 feet, extending from the benchmark measurement ( 0 feet) to 50 feet (Rains et al., 2006). 


\section{RESULTS AND DISCUSSION}

$\underline{\text { Site Characteristics and Analysis }}$

Vernal pools occur on a range of landscape depending on the physiographic region. In the northeastern US, the majority of vernal pools are located on glaciated materials (Brooks, 2003; Grant, 2005; Skidds and Golet, 2010). Of the 21 vernal pools I investigated within the Pawcatuck River watershed in southern Rhode Island, 16 formed in glaciofluvial sediments on kame terraces, outwash plains, and moraines (Table 1.1). The other 5 were on till uplands and drumlins, with one on a floodplain. Approximately $60 \%$ of the Pawcatuck River Watershed is composed of till and $25 \%$ glaciofluvial deposits (August et al., 1995). Of the 1039 vernal pools Skidds and Golet (2010) identified in the Pawcatuck River watershed, $43 \%$ were on glaciofluvial landscapes while $37 \%$ occurred in till. This suggests that my site characterization may be biased toward glaciofluvial vernal pools.

These wetlands can be partitioned into two components; the flat basin in the center of the pool, and the adjacent sloping upland. The transitional zone (zone 2) occurs at the intersection of these two areas. Average percent slopes of the area adjacent to the basins (transitional zone) varied from 3 to $20 \%$, with a mean of $8 \%$ (Table 1.1). These values represent the slope of the land extending between the basin and transitional wells (Figure 1.1). While glaciofluvial vernal pools were found to have both the maximum and minimum slopes reported, only $31 \%$ of the glaciofluvial sites had an average slope greater than the mean (Table 1.1). This wide range of morphological characteristics in the basins and their adjacent slopes is largely due to 
the variety of glaciated landforms associated with glaciofluvial parent material (Tiner, 2003; Skidds and Golet, 2005).

Vernal pools are small depressional wetlands which typically have basin areas $<0.1$ ha $\left(1000 \mathrm{~m}^{2}\right)$. Skidds and Golet (2005) and Rhienhart et al. (2007) defined the basins as the portion of the wetland that experiences inundation, indicated by the high water marks on surrounding vegetation. This definition differs from the method by which I defined my hydrologic zones, in which the transitional zone also experienced periods of inundation (Table 1.2). For the purpose of this study, I established the edge of the basin zone at the point where the landscape began to increase in gradient. Distinguishing a transitional zone from the flat basin zone allowed for a more in-depth analysis of portions of the wetland exhibiting differences in morphology and hydrology. All of the sites I investigated had basins far less than $1000 \mathrm{~m}^{2}$ (Table 1.1). Brooks et al. (1998) reported that of the 430 vernal pools they investigated in Massachusetts, no pool basin was larger than $500 \mathrm{~m}^{2}$. Skidds (2003) reported much larger maximum basin sizes, some ranging upwards of $6000 \mathrm{~m}^{2}$. These basin area measurements were made by calculating the areas in ArcGIS and by making field measurements. Skidds (2003) found that of pools $<500 \mathrm{~m}^{2}$, ArcGIS measurements were fairly inaccurate. Calculating basin areas based on field measurements may allow for a more accurate assessment of vernal pool sizes on different soil parent materials.

On average, vernal pools on dense till had a greater basin size than any of the other parent materials. In contrast, Skidds (2003) reported that glaciofluvial vernal pools had the largest average basin area. One possible reason for this difference is that 
I only investigated two vernal pools with dense till while Skidds (2003) examined 65 pools. When fit with a linear regression, basin size was not correlated with the average slope of the surrounding landscape $\left(R^{2}=0.03\right)$. This suggests that while vernal pool slope and size are important characteristics to consider, especially when monitoring and modeling hydrology, they are apparently not related in the glacial landscapes I studied.

$\underline{\text { Hydrology }}$

Four of the 21 vernal pools evaluated in ArcGIS, 4 were selected for in-depth analysis of hydrology, soils, and vegetation. Water table levels varied among the three hydrologic zones (Figure 1.1). In all hydrologic zones water table depth increased as atmospheric temperature increased (Figure 1.2). In vernal pools, water is lost to the atmosphere primarily through the process of evapotranspiration (Hanes, 2003; Brooks et al., 2004), which follows increases in temperature in the spring when the plants leaf out and drops in the fall when the plants lose their leaves. Thus, water table levels are lowest in the summer months as evapotranspiration increases and soils lose their moisture. In the winter, evapotranspiration is limited and the water table levels respond to precipitation by rising and staying at the highest levels (Figure 1.1).

Water table depths ranged from $70 \mathrm{~cm}$ above the soil surface to more than 155 $\mathrm{cm}$ below the surface (Table 1.2). At times, water table levels in the upland zone were over a meter lower than those in the basin zones. The upland was the only hydrologic zone that never became inundated with water. Water table levels in the basin zones resided closest to the soil surface for the longest period of time, in some cases staying at or above the surface for 71 consecutive days (Table 1.3). Even the transition zones 
in the CAR 2 and CAR 3 had water tables at or above the soil surface for extended periods of time (52 and 46 consecutive days, respectively) in the spring of 2016 (Table $1.3)$.

Comparison of vernal pool elevations with hydrological measurements allowed for an assessment of the water table gradients of each pool (Figure 1.3). When the water table resided deep below the soil surface, the gradient appeared to follow the slope between the transitional and upland zones. While two of the gradients stayed consistent regardless of the month (CAR 2 and GS), the other two appeared to reverse toward the upland when the basin experienced surface inundation (CAR 3 and EP). Hanes (2003) analyzed the hydraulic gradient of vernal pools in an attempt to quantify the impact that various landscape characteristics and water sources have on vernal pool hydrology. In that study, Hanes (2003) found that the relative elevation of a vernal pool must be considered when evaluating groundwater hydrology patterns. In vernal pools with steeper slope gradients surrounding the basin, surface runoff may result in reversed groundwater patterns (Hanes, 2003). The two vernal pools that I studied in which gradient reversal occurred also had the highest percent slopes (Table $1.1)$.

Understanding hydrologic patterns during the growing season is critical when evaluating hydric soil conditions and identifying hydric soils (Megonigal et al., 1996; Ford, 2014; USDA-NRCS, 2016). Two growing seasons were identified based on soil temperature: April 4, 2015 to January 20, 2016 and March 9 to October 19, 2016 (when the loggers were removed from the sites). Out of the 7 months of the 2015 growing season, 5 months had precipitation totals that fell between the $30^{\text {th }}$ and $70^{\text {th }}$ 
percentile of the 30-year average of monthly precipitation. This precipitation window was obtained from Kingston, RI WETS table (USDA-NRCS, 2005). Hydrology data are consider valid for identifying wetland hydrology in hydric soils if precipitation totals fall between the $30^{\text {th }}$ and $70^{\text {th }}$ percentile (USDA-NRCS, 2016). In 2015, December was above the $70^{\text {th }}$ percentile, while the remaining month (November 2015) fell below the $30^{\text {th }}$ percentile. In the 2016 growing season, 2 months fell within the $30^{\text {th }}$ to $70^{\text {th }}$ percentile, while the remaining 4 months fell below the $30^{\text {th }}$ percentile (Figure 1.4).

Hydric soil criteria require 14 consecutive days of saturation in the upper part during the growing season (USDA-NRCS, 2016). All pools were dry between the months of July and November, 2015. When sampling began for the following field season, 3 out of 4 of the pools were inundated in May and June, then dry for the remainder of the summer. In the basin zone, all four vernal pools had water tables that resided within $25 \mathrm{~cm}$ of the soil surface for at least 14 consecutive days during both growing seasons. This indicates that all basin soils meet the saturating conditions required to be considered a hydric soil. Only one pool (GS) had the required duration of saturation in the transitional zone during the 2015 growing season; however, pools were not instrumented during April, which is a month during the growing season that typically has high water table levels. Transitional zones of all pools met these conditions during the 2016 growing season. Because 2016 was a drier year than 2015 (Figure 1.4), it can be assumed that if the pools had been instrumented during the April and early May portion of the growing season, the transitional zones in 2015 also 
would have met the saturation criteria necessary to be considered hydric soils. None of the upland soils met the required hydric soil saturation conditions.

\section{$\underline{\text { Soil Morphology }}$}

Soils in the vernal pools were classified as Spodosols, Inceptisols, and Histosols (Table 1.5; Table 1.6; see Appendix 6 for descriptions of the soils in each zone). All of the soils mapped in the upland zones were Inceptisols. These are young, underdeveloped soils that are the most common soil type found in Rhode Island (Rector, 1981). At the subgroup level, upland soils classified as either Typic or Oxyaquic Dystrudepts (Table 1.5). Typic classifications are representative of soils where water tables rarely rise within $50 \mathrm{~cm}$ of the soil surface (Table 1.3 and 1.4). The exception was the GS upland soil, which classified as Oxyaquic instead of Typic, and the water table was above $50 \mathrm{~cm}$ for as many as 12 consecutive days in 2016 (Table 1.3).

Three of the 4 transitional zone soils classified as Spodosols; either Oxyaquic Haplorthods or Typic Endoaquods (Table 1.5). Spodosols are soils in which aluminum and/or iron are chelated by organic matter and move into the subsoil accumulating in the B horizons in the podzolization process (Ugolini and Dahlgren, 1987). In areas with temperate climates like southern Rhode Island, Spodosols only form in wetland environments (D'amore et al., 2015). Transition zones represent the edge of the wetland with as much as 56 consecutive days with the water table within $25 \mathrm{~cm}$ of the soil surface. Considering the hydrology at these locations, one would expect all of the soils to be Aquods, yet two of the three transition Spodosols were Haplorthods. Stolt et al. (2016) investigated soil morphology of Spodosols in New 
England and the mid-Atlantic and found that $82 \%$ of the wetland Spodosols did not classify as Aquods. These combined results point to the difficulty of identifying the position of the water table by soil morphology in Spodosols and that the criteria associated with the Aquod suborder may need to be reevaluated.

Basin soils were inundated for as long as 71 consecutive days (Table 1.3). Three of these soils showed strong evidence of wetness classifying as Haplosaprists, Endoaquods, and Endoaquepts (Table 1.5). The exception was at Carolina 3, where even though inundation was as long as 68 consecutive days (Table 1.3), the soil classified as a Haplorthod. All the basins had similar lengths of inundation, yet only in the basin of EP did a soil meet the criteria as a Histosol (Table 1.5). Histosols are soils that are composed primarily of organic material and common in areas inundated for long periods of time (Fanning and Fanning, 1989). Inundation maintains anaerobic conditions and typically slows organic matter decomposition (Mausbach and Richardson, 1990). The EP site was likely the wettest of the four study sites with at least 65 days of inundation in both years of the study, and in 2016 at least 166 days where the water table was above $50 \mathrm{~cm}$ (Table 1.4). In addition, the slope of the land surrounding the EP basin was the greatest of all the study sites (Table 1.1). Increased landscape gradients leading into vernal pool basins can cause organic rich materials such a leaf litter and deadfall to accumulate at a greater rate than pools with gentle slopes surrounding their basins (Hanes and Stromberg, 1998; Wang et al, 2005). Although I only sampled one Histosol in my research, further investigations of the landscape characteristics of vernal pools with Histosol soils may provide insight into a relationship between these characteristics and the formation of Histosols. 


\section{$\underline{\text { Hydric Soils }}$}

Soils were classified as hydric or non-hydric (Table 1.5) using the national indicators (USDA-NRCS, 2016). Three indicators could be applied to idea hydric soils in the basin and transitional zones: TA6, A11, and A1. The TA6 indicator is a test indicator and was developed after investigations revealed a lack of indicators that adequately describe hydric spodic soils. This indicator applies to soils that possess spodic horizons that meet specific depth and color qualifications. Soils associated with the A11 indicator have a thick, dark surface horizon that lies above a depleted matrix. The A1 indicator is a Histosol (USDA-NRCS, 2016). Soils from three of the four basin zones sampled matched hydric soil indicators: TA6 (n=1), A11 (n=1), and A1 $(n=1)$. Similarly, three out of the four transitional zone soils met morphologies described under hydric soil indicators: TA6 $(n=2)$ and A11 $(n=1)$. Two of the soils mapped in the basin and transition zones did not match any hydric soil indicator.

When designing this study, I utilized the hydrologic characteristics in order to distinguish the three zones of each vernal pool. I expected that the basin and transitional zones would possess hydric soils and this held true for all of the vernal pools. Two of the wettest soils, however, did not meet any hydric soil indicators: one transitional soil in CAR 2, and one basin soil in CAR 3. Both soils met the saturation requirements for a hydric soil (Table 1.3). These soils had soil morphologies very similar to the TA6 indicator; however, they did not meet the depth requirements for this indicator. When creating the TA6 indicator, 17 of the 18 pedons used to develop the TA6 indicator had spodic horizons within $30 \mathrm{~cm}$ of the soil surface; thus, a $30 \mathrm{~cm}$ or less benchmark was established for the upper boundary of the spodic horizon in the 
TA6 indicator (NHSTC, 2008). One of the 18 profiles that met wetland hydrology criteria, however, had a spodic horizon that began at a depth similar to that of the aforementioned CAR 2 and CAR 3 soils $(\sim 40 \mathrm{~cm})$. Because this is a test indicator, the possibility exists that the criteria will need to be adjusted in order to account for the broad range of morphological characteristics that Spodosols possess.

$\underline{\text { Vegetation Analysis }}$

Throughout the three hydrologic zones I encountered 21 different plant species (Table 1.7). While I found many of the same plant species throughout the study sites, these commonly observed species differed in frequency across all pools and zones. Acer rubrum, Thylepterus simulata, Vacciniym corymbosum, and Clethra alnifolia were present in the largest number of pools $(n=4)$. Out the total of 12 zones I investigated (3 zones per pool; 4 pools), I encountered Acer rubrum in the most zones $(\mathrm{n}=8)$, followed by Vacciniym corymbosum and Clethra alnifolia $(\mathrm{n}=7)$. These species are very commonly found throughout forested wetlands in New England (Skidds, 2003; Ricker, 2010).

Herbs were the dominant strata in all four basins (Figure 1.5). Dominant herb species in the basin included Bidens sp., Leersia oryzoies, and Dulichium arundinaceum. These three species were only found in basins that experienced extended periods of inundation: CAR 2, CAR 3, and EP (Table 1.7). Two out of the three species found in the basin of GS were not found in any other vernal pool basin (Thelypterus simulata and Smilax rotundifolia). The shortest period of basin inundation was in the GS site (Table 1.7). This may have contributed to the differences in vegetation (Table 1.4). One limitation when comparing species richness 
and length of inundation in vernal pool basins is the variable nature of herbaceous vegetation. Herbaceous vegetation emerges over the span of the entire growing season (Stewart and Kantrud, 1971) and dominant species may vary at different points throughout the growing season; however, I only sampled once during this period. Since vegetation in basin zones is primarily herbaceous, relating species richness and dominance to vernal pool hydrology may be both difficult and unreliable.

The transitional and upland zones were dominated by shrubs. Vaccinium corymbosum and Clethra alnifolia were the most common shrub species found in the transitional and upland zones. The distinct differences in strata between the different hydrologic zones supports the connection between vegetation and vernal pool hydrology, and is in line with the system currently used to categorize wetland plants by their indicator status: obligate (> 99\% occurrence in wetlands), facultative wetland (66-99\% occurrence in wetlands), facultative (33-66\% occurrence in wetlands), and facultative upland (1-33\% occurrence in wetlands; Table 1.7; USFWS, 2012). Herbs that dominated the vernal pool basins and could be identified to the species level all classified as obligate wetland plants. The frequent saturation and inundation of basin soils affirm the nature of the basin as a true wetland and facilitate the growth of these obligate wetland plants. Conversely, Vacciniym corymbosum and Clethra alnifolia are classified as facultative wetland and facultative plants, respectively. These plants rely less on the presence of wetland soils, which allowed them to thrive in the transitional and upland zones. 


\section{SUMMARY AND CONCLUSIONS}

The objectives of this part of my study were to characterize the landscape characteristics of vernal pools and evaluate their impact on edaphic and hydrologic conditions. Vernal pools were found on kame terraces, outwash plains, moraines, till uplands, and floodplains. All basin areas were $<1000 \mathrm{~m}^{2}$, which are the areas reported for most New England Vernal pools. Slopes ranged from 3 to 20\%, and were not correlated with average slope of the surrounding area, suggesting that although these are important characteristics to consider when monitoring and modeling hydrology, they are not related in the glacial landscapes I studied. Basin zones exhibited extended periods of inundation, and even transitional zones were inundated for up to 52 consecutive days. Water table patterns and fluctuations followed precipitation and evapotranspiration; with periods of inundation in the late winter and spring when evapotranspiration rates were at their lowest. When the water table resided deep below the soil surface, the water table gradient tended to follow the slope between the transitional and upland zones. Two of the pools, however, experienced reversal in the gradients (water table gradients sloped away from the basins). These two sites had the steepest slopes, which suggests there may be a reverse relationship at some times of the year between slope and water table gradient. This reverse relationship is likely due to increased rates of evapotranspiration from the transitional and upland soils, where less moisture is present, compared to the inundated basin zones.

All of the upland soils classified as Dystrudepts, indicative of their deeper water tables. Basin and transitional soil classifications varied between Haplosaprists, 
Endoaquods, Endoaquepts, and Haplorthods. While it might be expected to find Aquods in the wettest portions of the landscape, this was not the case for more than half of the Spodosols classified as Haplorthods. This suggests that the criteria associated with the Aquod suborder may need to be reevaluated.

I was able to apply three hydric soil indicators to basin and transitional zone soils: TA6, A11, and A1. Although all vernal pool basin and transitional zone soils met the saturation criteria required to be considered hydric soils, two of these soils did not meet any hydric soil indicators. These two soils possessed morphology very similar to that associated with the TA6 indicator; however, they did not meet all of the necessary requirements. The TA6 indicator was recently developed as a test indicator, suggesting that its criteria may need to be adjusted in order to account for the broader range of morphological characteristics.

Out of the 21 different plant species encountered throughout the vernal pool study sites, Acer rubrum, Thylepterus simulata, Vacciniym corymbosum, and Clethra alnifolia were present in the largest number of pools. Basin zones were dominated by herbaceous vegetation, while the transitional and upland zones were dominated by shrubs. The unique vegetation found in the basin zone that experienced the shortest period of inundation affirms the relationship between hydrology and vegetation. Furthermore, the plant species identified accurately reflected the hydrologic nature of each zone. 
Table 1.1. Site characteristics of a subset of 21 vernal pools in southern Rhode Island.

\begin{tabular}{|c|c|c|c|}
\hline Pool name & Landform & Basin area $\left(\mathrm{m}^{2}\right)$ & Slopes (\%) \\
\hline \multicolumn{4}{|c|}{ Glaciofluvial } \\
\hline Carolina 2 & Kame terrace & 12 & 9 \\
\hline Carolina 3 & Kame terrace & 114 & 14 \\
\hline Frank's Big Pond & Kame terrace & 381 & 7 \\
\hline Meadowbrook West & Kame terrace & 144 & 6 \\
\hline Punch Bowl Trail & Kame terrace & 155 & 4 \\
\hline $\begin{array}{l}\text { Small Pond Road } \\
\text { South }\end{array}$ & Kame terrace & 164 & 3 \\
\hline Amtrack & Outwash plain & 115 & 17 \\
\hline Aquapaug & Outwash plain & 11 & 6 \\
\hline Granquist & Outwash plain & 8 & 7 \\
\hline Meadowbrook Spur & Outwash plain & 30 & 7 \\
\hline TNC Decodon & Outwash plain & 288 & 7 \\
\hline Great Swamp & Outwash plain & 58 & 4 \\
\hline Blitzkrieg North & Moraine & 168 & 6 \\
\hline Blitzkrieg South & Moraine & 40 & 20 \\
\hline Eppley & Moraine & 35 & 16 \\
\hline Top Hill & Moraine & 49 & 8 \\
\hline Mean & & 111 & 9 \\
\hline \multicolumn{4}{|c|}{ Dense till } \\
\hline Small Pond Road & Moraine & 281 & 7 \\
\hline Audobon Fisherville & Till upland & 199 & 7 \\
\hline Mean & & 240 & 7 \\
\hline \multicolumn{4}{|c|}{ Loose till } \\
\hline Audobon Oak Trail & Till upland & 34 & 3 \\
\hline Diftway & Till upland & 6 & 10 \\
\hline Mean & & 20 & 7 \\
\hline \multicolumn{4}{|c|}{ Alluvium } \\
\hline Carolina Middle & Floodplain & 12 & 5 \\
\hline
\end{tabular}


Table 1.2. Summary of water table measurements made by Odyssey loggers at each study site. These values represent the depth to the water table below the soil surface $(\mathrm{cm})$; negative values indicate that the water table extended above the soil surface (surface inundation). The lowest depth is the lower extent of the logger at times when the water table likely was below that depth but a measurement could not be obtained. CAR 2 and CAR 3 shared their upland well between the two pools. No logger was placed in the upland zone of EP; these values are derived from manual water table measurements. Staff gauge data supplemented basin measurements when the water table surpassed the height of the well.

\begin{tabular}{ll|ccc}
\hline & & & & \\
Pool & Zone & Median & Highest & Lowest \\
\hline CAR 2 & Basin & 18 & -70 & 68 \\
CAR 3 & Basin & 32 & -69 & 73 \\
EP & Basin & 7 & -34 & 73 \\
GS & Basin & 29 & -23 & 85 \\
\hline CAR 2 & Transitional & 89 & -5 & 116 \\
CAR 3 & Transitional & 81 & -14 & 108 \\
EP & Transitional & 36 & -4 & 115 \\
GS & Transitional & 70 & -5 & 77 \\
\hline CAR 2 & Upland & 126 & 49 & 127 \\
CAR 3 & Upland & 126 & 49 & 127 \\
EP & Upland & 145 & 106 & 145 \\
GS & Upland & 108 & 19 & 155 \\
\hline
\end{tabular}

Note: CAR 2 = Carolina 2; CAR 3 = Carolina 3; EP = Eppley; GS = Great Swamp 
Table 1.3. Consecutive number of days during which the water table was above established benchmarks during the growing season. Two growing seasons were identified and investigated in order to encompass the length of my study. Data obtained from staff gauges were used to supplement water table information obtained in the basin before loggers were installed in the vernal pools.

\begin{tabular}{|c|c|c|c|c|c|c|c|c|c|}
\hline \multirow[b]{2}{*}{ Pool } & \multirow[b]{2}{*}{ Zone } & \multicolumn{3}{|c|}{$\begin{array}{c}\text { May } 2015- \\
\text { January } 2016 \\
\end{array}$} & \multirow[b]{2}{*}{$50 \mathrm{~cm}$} & \multicolumn{3}{|c|}{$\begin{array}{l}\text { March } 2016 \text { - } \\
\text { August } 2016\end{array}$} & \multirow[b]{2}{*}{$50 \mathrm{~cm}$} \\
\hline & & $0 \mathrm{~cm}$ & $10 \mathrm{~cm}$ & $25 \mathrm{~cm}$ & & $0 \mathrm{~cm}$ & $10 \mathrm{~cm}$ & $25 \mathrm{~cm}$ & \\
\hline CAR 2 & Basin & 49 & 55 & 64 & 74 & 71 & 74 & 87 & 98 \\
\hline CAR 3 & Basin & 49 & 49 & 61 & 72 & 68 & 72 & 77 & 90 \\
\hline EP & Basin & 57 & 69 & 94 & 124 & 65 & 72 & 87 & 92 \\
\hline GS & Basin & 19 & 19 & 23 & 25 & 47 & 51 & 54 & 65 \\
\hline CAR 2 & Transitional & 0 & 1 & 6 & 7 & 52 & 52 & 59 & 70 \\
\hline CAR 3 & Transitional & 0 & 0 & 0 & 0 & 46 & 51 & 56 & 67 \\
\hline $\mathrm{EP}$ & Transitional & 0 & 0 & 2 & 19 & 2 & 31 & 49 & 75 \\
\hline GS & Transitional & 0 & 7 & 19 & 23 & 2 & 12 & 43 & 53 \\
\hline CAR 2 & Upland & 0 & 0 & 0 & 0 & 0 & 0 & 0 & 4 \\
\hline CAR 3 & Upland & 0 & 0 & 0 & 0 & 0 & 0 & 0 & 4 \\
\hline $\mathrm{EP}$ & Upland & 0 & 0 & 0 & 0 & 0 & 0 & 0 & 0 \\
\hline GS & Upland & 0 & 0 & 0 & 3 & 0 & 0 & 0 & 12 \\
\hline
\end{tabular}

Note: CAR 2 = Carolina 2; CAR 3 = Carolina 3; EP = Eppley; GS = Great Swamp

Table 1.4. Cumulative number of days during which the water table was above established benchmarks during the growing season. Two growing seasons were identified and investigated in order to encompass the length of my study. Data obtained from staff gauges was used to supplement water table information obtained in the basin before loggers were installed in the vernal pools.

\begin{tabular}{|c|c|c|c|c|c|c|c|c|c|}
\hline \multirow[b]{2}{*}{ Pool } & \multirow[b]{2}{*}{ Zone } & \multicolumn{3}{|c|}{$\begin{array}{c}\text { May } 2015- \\
\text { January } 2016\end{array}$} & \multirow[b]{2}{*}{$50 \mathrm{~cm}$} & \multicolumn{3}{|c|}{$\begin{array}{l}\text { March } 2016 \text { - } \\
\text { August } 2016\end{array}$} & \multirow[b]{2}{*}{$50 \mathrm{~cm}$} \\
\hline & & $0 \mathrm{~cm}$ & $10 \mathrm{~cm}$ & $25 \mathrm{~cm}$ & & $0 \mathrm{~cm}$ & $10 \mathrm{~cm}$ & $25 \mathrm{~cm}$ & \\
\hline CAR 2 & Basin & 51 & 65 & 82 & 121 & 71 & 75 & 87 & 98 \\
\hline CAR 3 & Basin & 49 & 50 & 64 & 81 & 68 & 72 & 78 & 93 \\
\hline $\mathrm{EP}$ & Basin & 65 & 84 & 114 & 166 & 65 & 73 & 87 & 95 \\
\hline GS & Basin & 19 & 21 & 27 & 34 & 47 & 54 & 60 & 66 \\
\hline CAR 2 & Transitional & 0 & 1 & 6 & 7 & 52 & 52 & 60 & 70 \\
\hline CAR 3 & Transitional & 0 & 0 & 0 & 0 & 46 & 51 & 56 & 67 \\
\hline $\mathrm{EP}$ & Transitional & 0 & 0 & 3 & 35 & 13 & 32 & 54 & 75 \\
\hline GS & Transitional & 0 & 10 & 19 & 26 & 2 & 20 & 43 & 59 \\
\hline CAR 2 & Upland & 0 & 0 & 0 & 0 & 0 & 0 & 0 & 5 \\
\hline CAR 3 & Upland & 0 & 0 & 0 & 0 & 0 & 0 & 0 & 5 \\
\hline $\mathrm{EP}$ & Upland & 0 & 0 & 0 & 0 & 0 & 0 & 0 & 0 \\
\hline GS & Upland & 0 & 0 & 0 & 13 & 0 & 0 & 1 & 21 \\
\hline
\end{tabular}

Note: CAR 2 = Carolina 2; CAR 3 = Carolina 3; EP = Eppley; GS = Great Swamp 
Table 1.5. Taxonomic classifications and hydric soil indicators assigned to soils sampled from all hydrologic zones. A dash indicates that the soil did not meet any hydric soil indicator.

\begin{tabular}{lllc}
\hline Pool name & Zone & \multicolumn{1}{c}{ Classification } & Hydric soil indicator \\
\hline CAR 2 & Basin & Coarse-loamy Typic Endoaquept & A11 \\
CAR 3 & Basin & Coarse-loamy Oxyaquic Haplorthod & - \\
EP & Basin & Typic Haplosaprist & A1 \\
GS & Basin & Coarse-loamy Typic Endoaquod & TA6 \\
CAR 2 & Transitional & Coarse-loamy Oxyaquic Haplorthod & - \\
CAR 3 & Transitional & Coarse-loamy Oxyaquic Haplorthod & TA6 \\
EP & Transitional & Coarse-loamy Typic Endoaquept & A11 \\
GS & Transitional & Coarse-loamy Typic Endoaquod & TA6 \\
CAR 2 & Upland & Coarse-loamy Typic Dystrudept & - \\
CAR 3 & Upland & Coarse-loamy Typic Dystrudept & - \\
EP & Upland & Coarse-loamy Typic Dystrudept & - \\
GS & Upland & Coarse-loamy Oxyaquic Dystrudept & - \\
\hline
\end{tabular}

Note: CAR 2 = Carolina 2; CAR 3 = Carolina 3; EP = Eppley; GS = Great Swamp 
Table 1.6. Morhpological descriptions of common soil types found throughout the vernal pool study sites and an associated glossary of abbreviations.

Coarse-loamy Oxyaquic Haplorthod (CAR 3; Transitional Zone)

\begin{tabular}{c|ccccc}
\hline & $\begin{array}{c}\text { Lower } \\
\text { Depth } \\
\text { Horizon }\end{array}$ & $\begin{array}{c}\text { Texture } \\
\text { Class }\end{array}$ & Color & Depletions & Concentrations \\
\hline Oe & 4 & Hemic & 10 YR 3/2 & - & - \\
AE & 28 & FSL & 10 YR 2/1 & - & - \\
Bhs1 & 60 & SL & $7.5 Y R 3 / 1$ & - & - \\
Bhs2 & 89 & SL & 10 YR 3/2 & - & - \\
Bhs3 & 117 & COSL & $7.5 Y R 3 / 1$ & Few, dist. & Com., dist. \\
Bhs4 & $130+$ & SL & $7.5 Y R 3 / 3$ & Few, dist. & Com., dist.
\end{tabular}

Typic Haplosaprist (EP; Basin Zone)

\begin{tabular}{c|ccccc}
\hline & $\begin{array}{c}\text { Lower } \\
\text { Depth } \\
\text { Horizon }\end{array}$ & $\begin{array}{c}\text { Texture } \\
\text { Class }\end{array}$ & Color & Depletions & Concentrations \\
\hline Oe & 3 & Hemic & 10YR 2/2 & - & - \\
Oa1 & 25 & Sapric & 10YR 2/1 & - & - \\
Oa2 & 65 & Sapric & 10YR 3/1 & - & - \\
Oa3 & 95 & Sapric & 10YR 2/1 & - & - \\
Oa4 & $120+$ & Sapric & 10YR 2/1 & - & -
\end{tabular}

Coarse-loamy Typic Endoaquept (CAR 2; Basin Zone)

\begin{tabular}{c|ccccc}
\hline Horizon & $\begin{array}{c}\text { Lower } \\
\text { Depth } \\
(\mathrm{cm})\end{array}$ & $\begin{array}{c}\text { Texture } \\
\text { Class }\end{array}$ & Color & Depletions & Concentrations \\
\hline $\mathrm{Oe}$ & 3 & Hemic & 10 YR 2/2 & - & - \\
$\mathrm{A}$ & 11 & SIL & 10YR 2/1 & - & - \\
$\mathrm{Bg} 1$ & 53 & COSL & 2.5 Y 3/1 & Com., Fnt. & Few, Fnt. \\
$\mathrm{Bg} 2$ & 92 & LCS & 5Y 4/1 & Com., Fnt. & - \\
$\mathrm{Bg} 3$ & 114 & LCS & 5 Y 3/1 & Com., Fnt. & - \\
$\mathrm{Ab}$ & 120 & SIL & $2.5 Y 2.5 / 1$ & Few, Dist. & - \\
$\mathrm{Bgb}$ & $150+$ & SIL & 5Y 4/1 & Many, Dist. & Few, Fnt.
\end{tabular}


Coarse-loamy Typic Dystrudept (EP; Upland Zone)

\begin{tabular}{c|ccccc}
\hline & $\begin{array}{c}\text { Lower } \\
\text { Depth } \\
\text { Horizon }\end{array}$ & $\begin{array}{c}\text { Texture } \\
\text { Class }\end{array}$ & Color & Depletions & Concentrations \\
\hline Oi & 6 & Fibric & 10YR 2/2 & - & - \\
AE & 14 & SL & 10YR 3/2 & - & - \\
Bw1 & 32 & SL & 10YR 3/3 & - & - \\
Bw2 & 68 & COSL & 10YR 4/4 & - & - \\
Bw3 & 91 & COSL & 10YR 4/6 & - & - \\
BC & 120 & LCS & 10YR 4/4 & - & - \\
C & $150+$ & LCS & 10YR 5/6 & - & -
\end{tabular}

Abbreviations

\begin{tabular}{l|l} 
Abbreviation & Meaning \\
\hline Com. & Common \\
COSL & Coarse sandy loam \\
Dist. & Distinct \\
Fnt. & Faint \\
FSL & Fine sandy loam \\
LCS & Loamy coarse sand \\
Prom. & Prominent \\
SIL & Silt loam \\
SL & Sandy loam
\end{tabular}


Table 1.7. Plant species dominating each hydrologic zone during the summer of 2016. Number of pools refers to the number of vernal pools in which the species was found. Frequency across all pool zones refers to the number of hydrologic zones in which the species was found when combining data from all four study sites (out of a total of 12 zones across all pools; 3 per site). A dash indicates that the plant could not be classified to the species level and thus the common name and wetland indicator status could not be identified.

\begin{tabular}{llcccc}
\hline & Common Name & Stratum & $\begin{array}{c}\text { Number } \\
\text { of pools }\end{array}$ & $\begin{array}{c}\text { Frequency } \\
\text { across all } \\
\text { pool zones }\end{array}$ & $\begin{array}{c}\text { Wetland } \\
\text { indicator } \\
\text { status }\end{array}$ \\
\hline Acentific Name & Red maple & Tree & 4 & 8 & FAC \\
Clethra alnifolia & Sweet pepper-bush & Shrub & 4 & 7 & FAC \\
Vaccinium corymbosum & Highbush-blueberry & Shrub & 4 & 7 & FACW \\
Sphagnum palustre & Peat moss & Herb & 3 & 6 & OBL \\
Thelypterus simulata & Massachusetts fern & Herb & 4 & 5 & FACW \\
Dulichium arundinaceum & Threeway sedge & Shrub & 3 & 3 & OBL \\
Pinus strobus & White pine & Tree & 3 & 3 & FACU \\
Smilax rotundifolia & Common greenbrier & Shrub & 1 & 3 & FAC \\
Lyonia ligustrina & Male-berry & Shrub & 2 & 2 & FACW \\
Osmundastrum cinnomomea & Cinnamon-fern & Herb & 2 & 2 & FACW \\
Quercus alba & White oak & Tree & 2 & 2 & FACU \\
Bidens sp. & - & Herb & 1 & 1 & - \\
Carex stricta & Tussock sedge & Herb & 1 & 1 & OBL \\
Decodon verticillatus & Swamp loosestrife & Herb & 1 & 1 & OBL \\
Dicanthelium sp. & - & Herb & 1 & 1 & - \\
Fagus grandifolia & American beech & Tree & 1 & 1 & FACU \\
Gratiola aurea & Yellow hedge-hyssop & Herb & 1 & 1 & OBL \\
Juncus sp. & Herb & 1 & 1 & - \\
Leersia oryzoies & Rice cut-grass & Herb & 1 & 1 & OBL \\
Pinus rigida & Pitch-pine & Tree & 1 & 1 & FACU \\
Rhododendron viscosum & Swamp-azalea & Shrub & 1 & 1 & FACW \\
\hline & & & & & \\
\hline
\end{tabular}

Note: $\mathrm{UPL}=$ upland $; \mathrm{FACU}=$ facultative upland $; \mathrm{FAC}=$ facultative $; \mathrm{FACW}=$ facultative wetland; $\mathrm{OBL}=$ obligate 


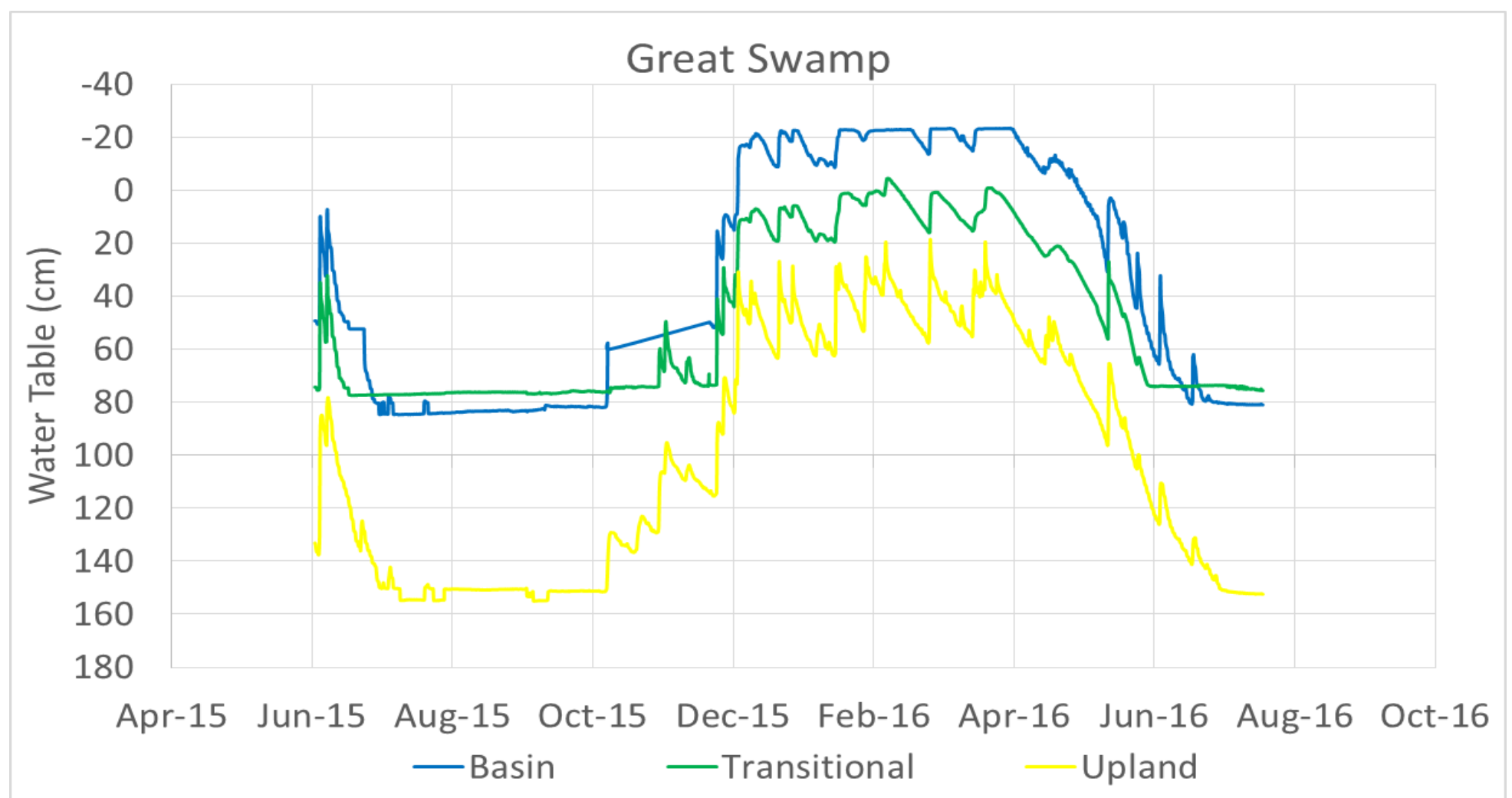

Figure 1.1. Odyssey logger measurements for Great Swamp over the course of this study. Measurements represent the water table levels in each hydrologic zone at all sites. Negative values indicate that the water table breached the soil surface and inundation was present. The hydrographs reflecting the rise and fall of the water table do not include staff gauge measurements; black data points represent staff gauge measurements made when the basin zone was inundated. The maximum logger measurement $(\sim 150 \mathrm{~cm}) \mathrm{was}$ made when water tables dropped below the extent of the logger. The logger was removed from the basin zone between the months of November and December (2015) for recalibration purposes. 


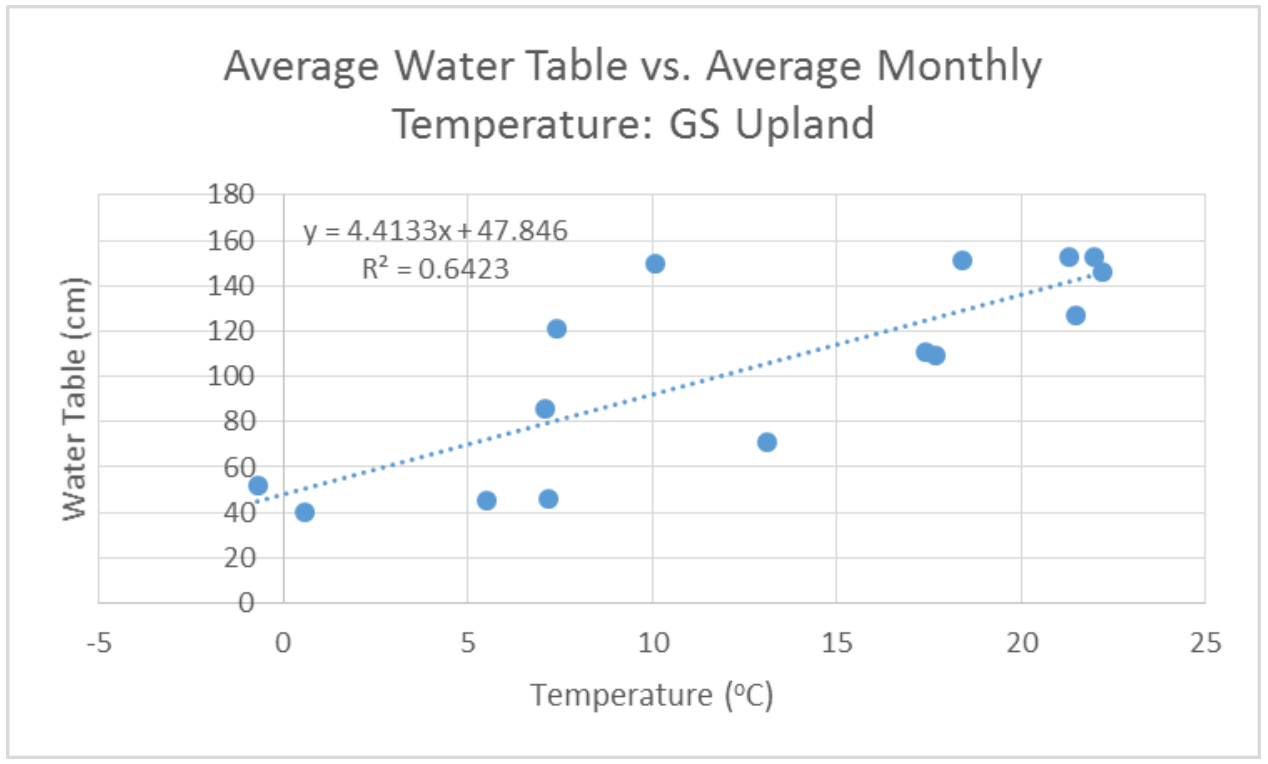

Figure 1.2. Regression analysis of average water table levels compared to average monthly temperature (obtained from the Kingston WETS station: RI4266). 

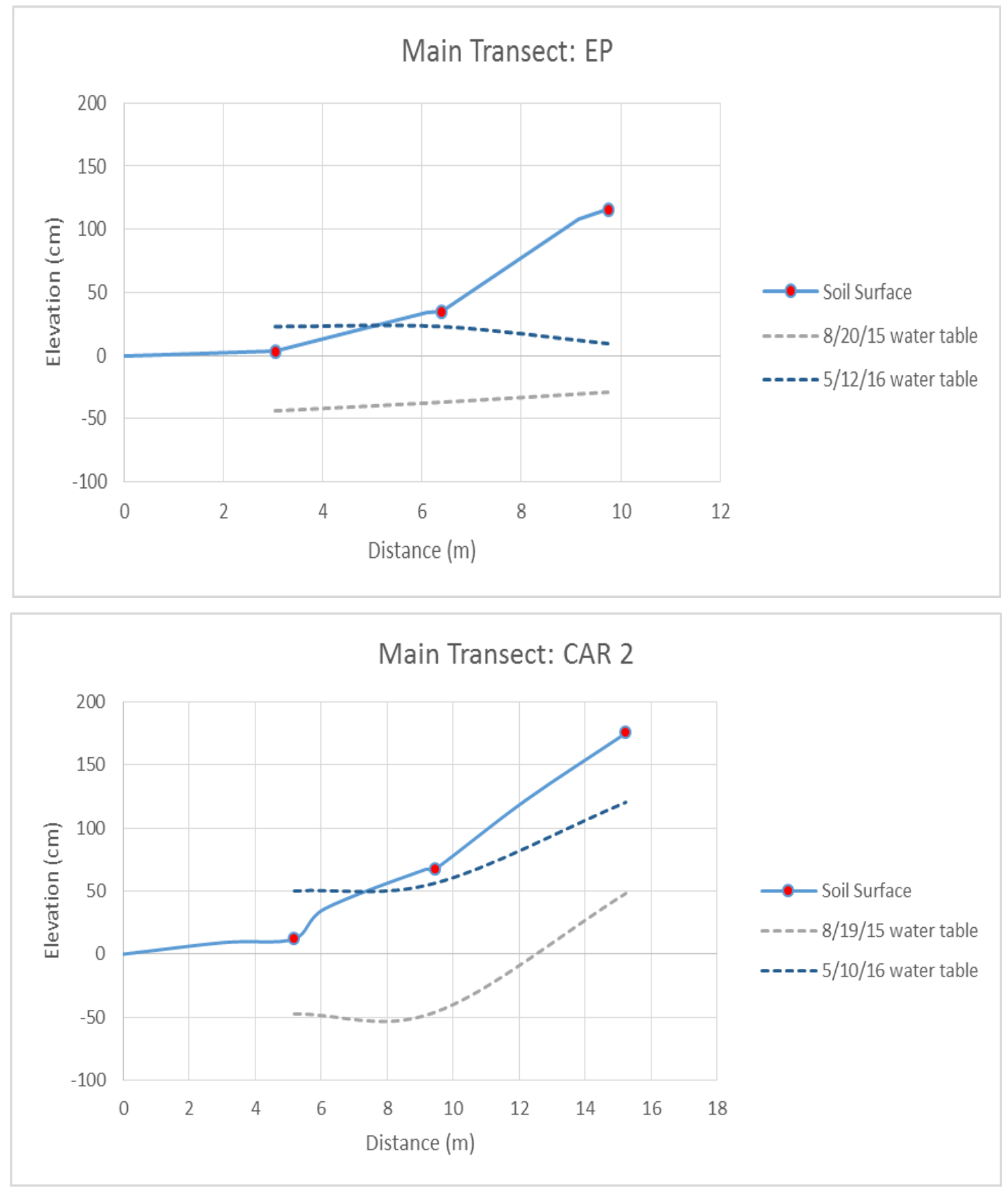

Figure 1.3. A representation of the water table gradient in the vernal pools. Water table levels measured during the months of August and May are represented in order to portray the rise and fall of the water table throughout the three hydrologic zones. Well locations are indicated with a red data point. Distance refers to the distance from the flattest point of the vernal pool basin. 


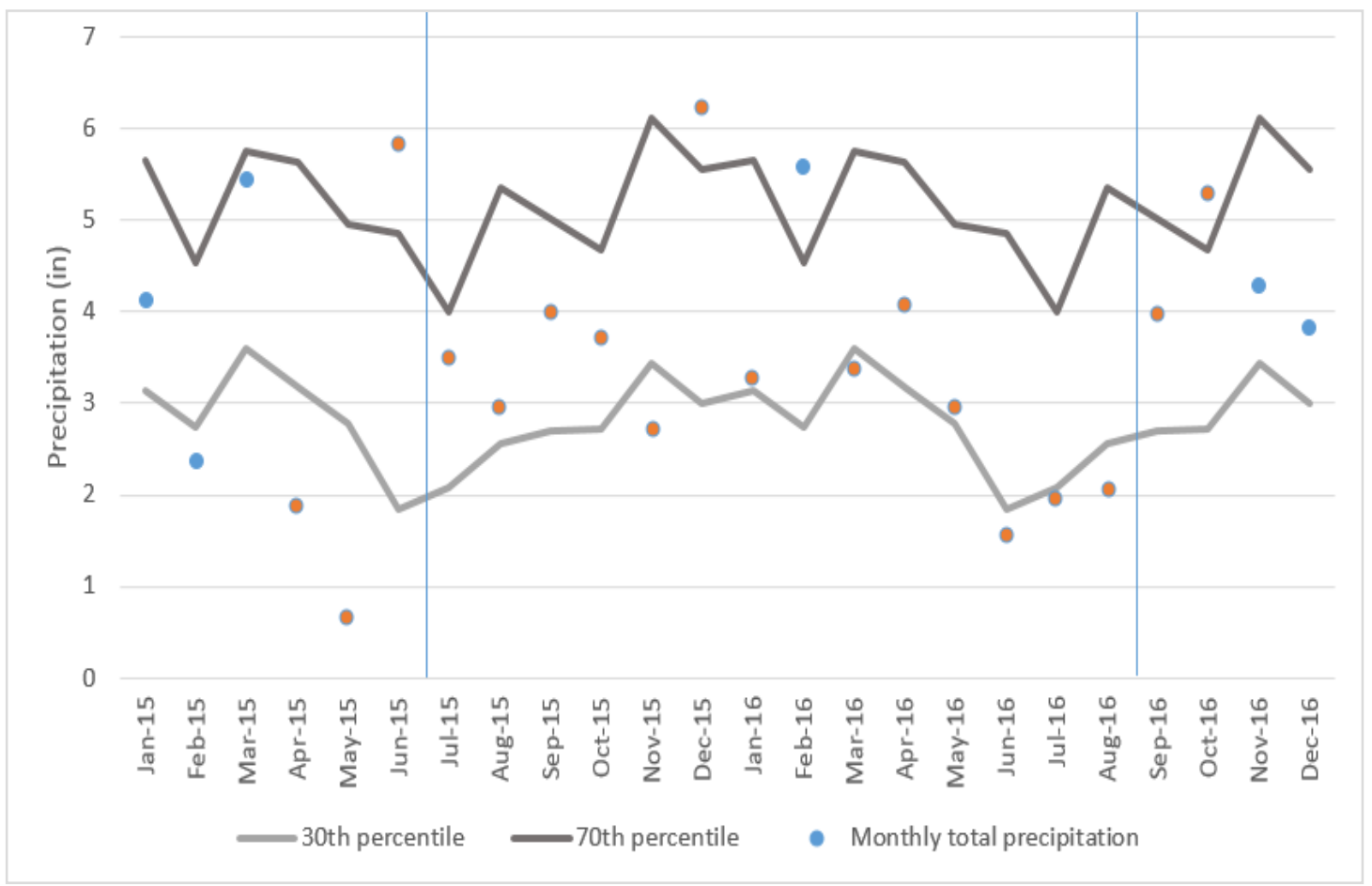

Figure 1.4. Local monthly precipitation for 2015 and 2016, as compared to the range of normal field conditions (obtained from the Kingston WETS station: RI4266). The upper limit refers to the $70^{\text {th }}$ percentile of 30 -yr average precipitation values, and the lower limit refers to the $30^{\text {th }}$ percentile of these values. Orange data points correspond with precipitation that occurred during the growing season. Blue data points correspond with precipitation that occurred outside of the growing season. The months during which I monitored water table levels fall between the two blue vertical lines. 


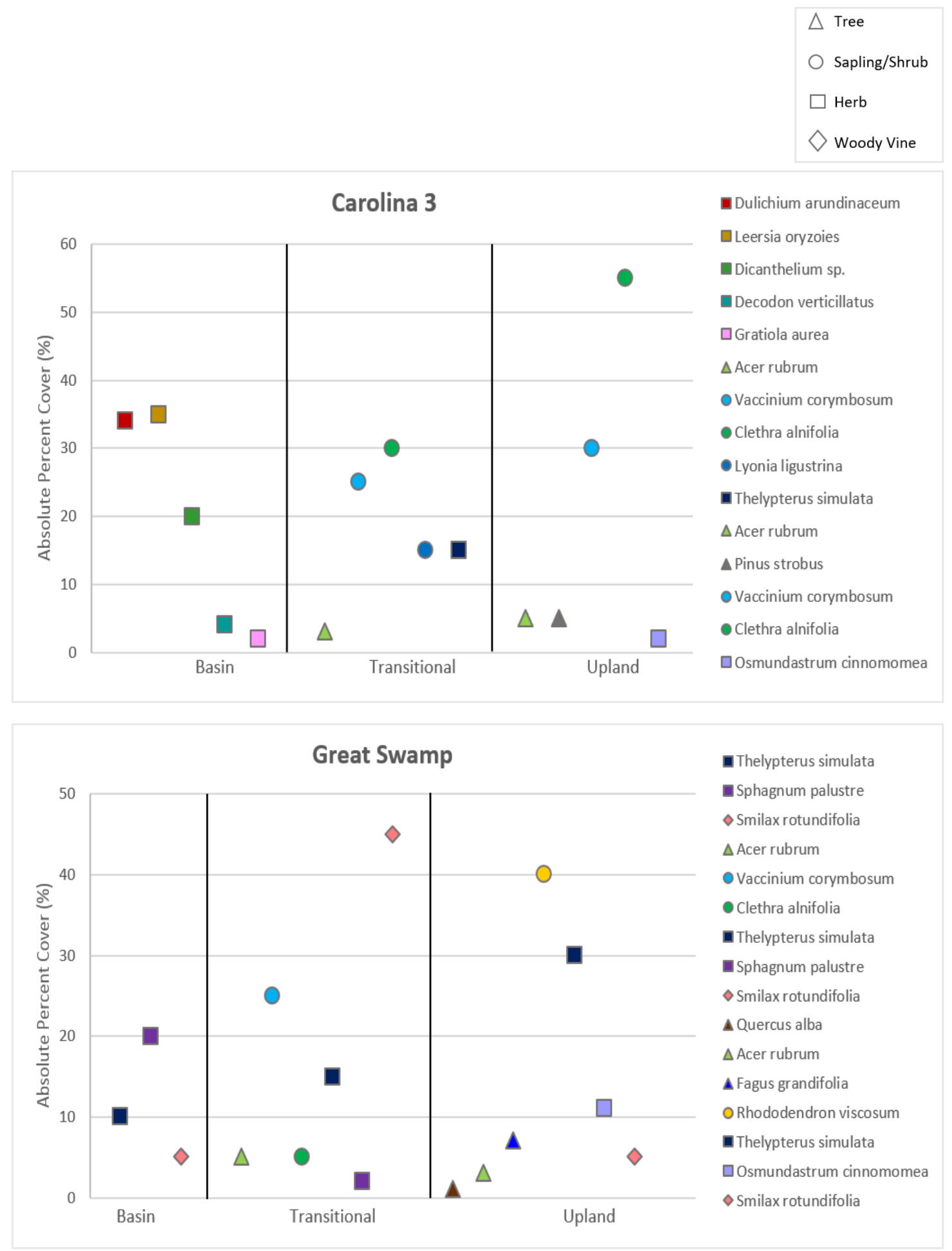

Figure 1.5. An analysis of the absolute percent cover of dominant vegetation in each vernal pool. Measurements were made in summer 2016. Data point color indicates the specific species, and shape indicates to which strata the species belongs. 


\title{
CHAPTER 2: HYDROLOGICAL IMPLICATIONS ON VERNAL POOL GAS FLUX AND CARBON STORAGE
}

\begin{abstract}
Wetlands are hotspots of biogeochemical activity. Due to their small size and variable wetting and drying cycles, few studies have attempted to quantify the biogeochemical impacts across the unique hydrologic gradients of vernal pools. In this study, carbon pools, organic matter decomposition, and greenhouse gas flux were investigated across three hydrologic zones in four vernal pools. Leaf litter bags and dowel rods were placed on the soil surface from July through September in 2015 and from June through August in 2016 to investigate decomposition. Dowel rods were also inserted into the soil to $25 \mathrm{~cm}$ in 2015 . Soil organic carbon (SOC) pools were calculated to $50 \mathrm{~cm}$ in each zone. On average, upland zones possessed the smallest SOC pool $\left(8 \mathrm{~kg} \mathrm{~m}^{-2}\right)$ and the basin and transitional zones possessed the largest pools $\left(11 \mathrm{~kg} \mathrm{~m}^{-2}\right)$. Leaf litter additions varied among hydrologic zones and sites ranging from 40 to $149 \mathrm{~g} \mathrm{C} \mathrm{m}^{-2}$. In 2015, the average loss of mass lost from the leaves applied ranged from $6(10 \%)$ to $12 \mathrm{~g} \mathrm{C} \mathrm{m}^{-2}(18 \%)$, with the highest loss exhibited by the basin zones. Above-ground decomposition of wooden dowels was also highest in the basin in 2015, ranging from 0.7 to $13 \%$ across all zones. Losses in 2016 followed similar trends, but losses were significantly lower, likely resulting from the lower amount of precipitation experienced by the vernal pools in 2016. Below-ground decomposition yielded 10 to $20 \%$ losses, with the highest decomposition occurring in the upland zone. Comparison of vernal pool hydrology with decomposition trended toward
\end{abstract}


significance for leaf litter losses $(p=0.06)$ and ground dowel losses $(p=0.07)$ in 2015; leaf litter decomposition increased as water table heights increased, while below-ground decomposition decreased as water table heights increased. Greenhouse gas flux was measured between the months of August and November, 2015, and between May and August, 2016. $\mathrm{CO}_{2}$ flux was significantly correlated with soil temperature $(\mathrm{p}<0.001)$ and hydrologic zone across all study sites $(\mathrm{p}=0.03)$. Flux increased as soil temperature increased and as soils became increasingly aerobic. Although the partitioning of heterotrophic and autotrophic respiration yielded weak correlations $\left(\mathrm{R}^{2}<0.5\right)$, analysis suggested that root respiration accounted for $<40 \%$ of the total $\mathrm{CO}_{2}$ flux. Mean monthly $\mathrm{CO}_{2}$ flux ranged from 5 to $22 \mu$ mole $\mathrm{m}^{-2} \mathrm{~min}^{-1}$ with transitional zones having the highest average flux values. Methane flux was significantly correlated with vernal pool hydrology in all study sites $(\mathrm{p}<0.003)$. Positive emissions ranged from 0.02 to $0.03 \mu$ mole $\mathrm{m}^{-2} \mathrm{~min}^{-1}$. These emissions occurred in the basin zones during the months of May and June when the basins were inundated. Virtually all transitional and upland zones exhibited net $\mathrm{CH}_{4}$ absorption, as did the basin zones during months other than May and June. Nitrous oxide fluxes from -0.009 to $0.008 \mu$ mole $\mathrm{m}^{-2} \mathrm{~min}^{-1}$ and did not vary significantly with hydrologic zone. Despite their small size and ephemeral nature, the significant role that they play in greenhouse gas flux and removal warrant continued investigation and conservation of vernal pools. 


\section{INTRODUCTION}

Anthropogenic activities have greatly disrupted earth's carbon cycle. The production and usage of fossil fuels has resulted in an increase of carbon dioxide $\left(\mathrm{CO}_{2}\right)$ in the atmosphere from $280 \mathrm{ppm}$ in 1750 to upwards of $400 \mathrm{ppm}$ today (IPCC, 2014; Betts et al., 2016). This increased emission of $\mathrm{CO}_{2}$, a potent greenhouse gas (GHG), poses a serious threat to the ecosystem by augmenting the effects of global climate change. The terrestrial reservoir stores much of the earth's carbon in the form of soil organic matter (SOM). Because of earth's large terrestrial carbon pool, the topic of soil carbon budgets for different landscapes is being increasingly debated within the scientific community (Smith et al., 1993; Huntington, 1995; Bridgham et al., 2006; Mitsch et al., 2012; Ricker et al., 2014). Wetlands, which are estimated to store $20-30 \%$ of the earth's terrestrial carbon pool (Mitsch et al., 2012), are but one of many landscape types under scrutiny in an attempt to mitigate the impacts of global climate change (IPCC, 2007).

The hydrologic characteristics and landscape setting of a vernal pool largely influence the processes that occur in wetland soils. The decomposition of organic matter is one important process that is largely influenced by these factors. Organic matter decomposition is dependent upon a number of factors, such as the source of the organic matter, soil temperature, soil moisture, and whether aerobic or anaerobic conditions are present. The length of time during which the soils exhibit anaerobic conditions also influences decomposition. Typically, wetland soils accumulate more soil organic matter (SOM) over time than upland soils because of the long periods of saturation that result in anaerobic conditions in these soils, ultimately slowing 
decomposition rates (Gorham, 1991; Groffman et al, 1996; USDA-NRCS, 2016). Studies on the variation in organic matter decomposition rates across hydrologic gradients of vernal pools have produced conflicting results, largely due to the unpredictable wet-dry cycles associated with the ephemeral nature of vernal pools (McClain et al., 2003; Capps et al., 2014).

Wetlands are hotspots of biogeochemical activity. Whether wetlands serve as net sources or sinks of carbon is dependent upon the biogeochemistry of the systems (Kuzyakov, 2005; Bridgham et al., 2006; Altor and Mitsch, 2008; Davis et al., 2010; Holgerson, 2015). Due to high plant productivity, wetlands are able to easily sequester carbon via plant uptake of atmospheric $\mathrm{CO}_{2}$ through photosynthesis. Plantderived carbon is added to the soil when the roots die or the plants drop leaves (Xiong and Nilsson, 1997) and deadfall (Brinson et al., 1981); contributing to the soil carbon pool. Over time SOM builds up in wetlands because the anaerobic conditions brought on by the saturated soils slow the rates of organic matter decomposition (Whiting and Chanton, 2001; Altor and Mitsch, 2008). These carbon stocks can be quantified and provide insight into the effectiveness of wetlands to serve as a carbon sink.

Organic matter is added to wetland environments by several key sources. For instance, trees contribute organic matter through deadfall and leaf litter deposition. Furthermore, plant roots provide a source of organic matter throughout soil profiles (Capps et al., 2014). Organic matter serves as an energy source that fuels microbial processes in the soil, creating products emitted not only into the soil, itself, but also into the atmosphere. These atmospheric emissions are of particular concern because they can take the form of several potent GHG: $\mathrm{CO}_{2}$, methane $\left(\mathrm{CH}_{4}\right)$, and nitrous oxide 
$\left(\mathrm{N}_{2} \mathrm{O}\right)$ (Moseman-Valiterra et al., 2011; Mitsch et al., 2012). Because of the important role that wetland landscapes such as vernal pools are considered to play in greenhouse gas models, understanding how differences in organic matter source and degree of soil saturation control the quantity of decomposition processes and the production of greenhouse gases is of the utmost importance.

In carbon sequestration studies, sources of carbon are typically associated with leaf litter (\%), deadfall (\%), and roots. Decomposition rates of these sources have been studied in a number of different ways. Mesh litter bags filled with leaves may be used to represent leaf litter deposited in the field, while wooden dowel rods placed at the soil surface may represent deadfall, and wooden dowel rods inserted into the soil may represent coarse roots (O’Lear et al., 1995; Austin and Vitousek, 2000; Bontti et al., 2000; Capps et al., 2014). One study by Capps et al. (2014) examined differences in leaf litter decomposition across a hydrologic gradient in forested vernal pools. This study found that the percent of leaf litter lost over approximately three months was significantly higher in the vernal pool basin $(\sim 38 \%)$ and transitional edge zone $(\sim 45 \%)$ than in the upland area $(\sim 28 \%)$. A similar study investigated leaf litter decomposition across different flooding regimes in a seasonally flooded Amazonian watershed. This study produced comparable trends in its results, revealing a percent loss of approximately $60 \%$ leaf litter in the intermittently-flooded zone and a loss of approximately $40 \%$ leaf litter in the dry upland (Capps et al., 2010).

Studies have also simulated deadfall and root decomposition through the examination of above-ground and below-ground dowel decomposition in a variety of different environments. Precipitation, temperature, and landscape disturbance are the 
variables primarily evaluated with dowel decomposition. After a span of approximately three months, several studies found that dowel decomposition did not exceed 10\% (O’Lear et al., 1995; Austin and Vitousek, 2000; Bontti et al., 2009). Little to no research has investigated the influence that the degree and duration of soil saturation has on dowel decomposition.

While wetland soils sequester carbon, they also serve as sources of $\mathrm{CO}_{2}$ through two primary biogeochemical methods: heterotrophic and autotrophic respiration. Heterotrophic respiration primarily results from microbial mineralization of organic matter. Soil microbes decompose SOM in order to utilize it as an energy source. Through respiration, the carbon is released into the atmosphere as $\mathrm{CO}_{2}$. Depending on environmental conditions, microorganisms will respire either aerobically (via the tricarboxylic acid cycle) or anaerobically (via fermentation). On the other hand, autotrophic respiration primarily results from the respiration of live plant roots (Raich and Schlesinger, 1992; Altor and Mitsch, 2008). Partitioning these two sources allows for a better understanding of the mechanisms behind $\mathrm{CO}_{2}$ flux (Hanson et al., 2000; Ricker et al., 2014). While $\mathrm{CO}_{2}$ flux has been studied extensively in many natural and simulated wetland environments (Raich and Potter, 1995; Bridgham et al., 2006; Altor and Mitsch, 2008; Mitsch et al., 2012; Ricker et al., 2014), research focused on measuring $\mathrm{CO}_{2}$ fluxes and partitionment to the fluxes in vernal pool wetlands is limited to non-existent.

Studies have found that estimates of root contribution to total $\mathrm{CO}_{2}$ flux greatly vary, ranging from 5\% to $90 \%$ (Andrews et al., 1999). Raich and Schlesinger (1992) examined the mechanisms of soil respiration in a forested soil and found that $26 \%$ of 
total soil respiration resulted from root respiration (autotrophic), while the remaining $74 \%$ was attributed to microbial decomposition of organic matter (heterotrophic respiration). In a study quantifying root respiration in forested riparian wetland and upland soils, Ricker et al. (2014) found that mean root respiration ranged from 32-63\% of total soil $\mathrm{CO}_{2}$ flux. While efforts have been made to partition the sources of $\mathrm{CO}_{2}$ flux in uplands and wetlands, separately, performing such a study in vernal pools allows for study across a unique hydrologic gradient.

Hydrology also plays a major role in other biological and chemical interactions that take place in the soil (Ricker et al., 2014). The unique characteristics of vernal pools allow for a diagnostic investigation of how the hydrology of a natural environment influences the magnitude of GHG emitted into the atmosphere. GHG such as $\mathrm{CO}_{2}, \mathrm{CH}_{4}$, and $\mathrm{N}_{2} \mathrm{O}$ all contribute the global warming of Earth (Altor and Mitsch, 2008). Due to the differences in the magnitude of their impact on global warming, GHG emissions should be evaluated individually. For instance, the potency of $\mathrm{CH}_{4}$ is 25 times that of $\mathrm{CO}_{2}$, while $\mathrm{N}_{2} \mathrm{O}$ has a potency of 298 times that of $\mathrm{CO}_{2}$. Global climate models predict that global surface temperatures will increase 1.5 to $4^{\circ}$ C by the year 2100 (IPCC, 2007). Long-term monitoring of vernal pool climate conditions, such as temperature and rainfall inputs, allows for an improved understanding of vernal pools' vulnerability to global warming.

Wetland soils play a key role in the global carbon cycle not only by contributing $\mathrm{CO}_{2}$, but also by producing $\mathrm{CH}_{4}$ through the process of methanogenesis. Methanogenesis is an anaerobic process in which microorganisms first degrade organic matter present in the soil. Methanogenic microorganisms utilize the acetate or 
hydrogen and $\mathrm{CO}_{2}$ produced by this decomposition in order respire, thus producing $\mathrm{CH}_{4}$ which can then be emitted into the atmosphere (Segers, 1997; Altor and Mitsch, 2008). There is a positive correlation between the amount of carbon fixed in wetlands to the amount of $\mathrm{CH}_{4}$ emitted into the atmosphere (Whiting and Chanton, 2001). Despite their small size, $\mathrm{CH}_{4}$ flux tends to be high in vernal pool wetlands as aerobic soil becomes inundated, reducing the soil's ability to oxidize $\mathrm{CH}_{4}$. When $\mathrm{CH}_{4}$ oxidation exceeds $\mathrm{CH}_{4}$ production through methanogensis, the area is considered to be a sink of $\mathrm{CH}_{4}$ rather than a source (Kuhn, 2015; Holgerson, 2015). Thus, this absorption of $\mathrm{CH}_{4}$ is typical in aerobic soil environments (Kagotani et al., 2001).

In addition to playing a key role in the global carbon cycle, wetland soils serve as an ideal environment for denitrification. Denitrification is the final step in the nitrogen cycle. In this anaerobic process, microorganisms reduce nitrogen oxides into nitrogen gases. In order for this process of reduction to occur, microorganisms need a source of organic carbon. The ultimate product of denitrification is di-nitrogen gas $\left(\mathrm{N}_{2}\right)$; however, if the process does not go to completion, intermediate gases can form and be released into the atmosphere. One prominent example of an intermediate nitrogen gas is $\mathrm{N}_{2} \mathrm{O}$, which is a potent $\mathrm{GHG}$ (Bernhard, 2010). Denitrification is dependent upon not only the carbon and oxygen available in soils, but also the concentration of nitrate $\left(\mathrm{NO}_{3}{ }^{-}\right)$available (Capps et al, 2014). Quantifying the nitrogen stocks in vernal pool soils, in addition to the carbon stocks, provides insight into the likelihood of nutrient cycling throughout the vernal pools and the emission of $\mathrm{N}_{2} \mathrm{O}$ into the atmosphere (Moseman-Valtierra et al., 2011). 
Many studies have investigated $\mathrm{CH}_{4}$ flux (Whiting and Chanton, 2001; Altor and Mitsch, 2008; Segers, 1997; Mitsch et al., 2012) and $\mathrm{N}_{2} \mathrm{O}$ flux (MosemanValtierra et al., 2011; Chuersuwan et al., 2014; Jorgensen et al., 2012) in wetland environments. However, very few studies have performed these investigation specifically in vernal pools. One study by Kuhn (2015) attempted to distinguish differences in $\mathrm{CH}_{4}$ emissions throughout various zones within vernal pools. This study was performed in several southern Massachusetts vernal pools, located on glacial outwash plains. $\mathrm{CH}_{4}$ flux measurements were obtained between the months of October 2014 and April 2015. Flux was measured across a gradient of pool hydrology and landscape position per gram of soil: pool basin, transitional edge zone, and upland area. Results across several study sites varied, revealing the highest $\mathrm{CH}_{4}$ production rates in the basin zones.

Another study divided several vernal pool sites into three similar zones and measured denitrification rates, or $\mathrm{N}_{2} \mathrm{O}$ production, in each zone after nutrient application. These study sites were located in Maine, and $\mathrm{N}_{2} \mathrm{O}$ fluxes were measured during the months of May and July 2013. Researchers also found a significant difference between upland denitrification rates and those of the basin and edge zones, as the upland zones consistently produced lower rates (Capps et al., 2014).

These results suggest that vernal pool position does influence $\mathrm{CH}_{4}$ and $\mathrm{N}_{2} \mathrm{O}$ emissions, and that there is a need for additional assessments of these relationships. However, these studies were limited by the time period during which sampling occurred. Neither study was able to encompass all four seasons in their research, which is critical in understanding vernal pool dynamics due to the various changes that 
vernal pools undergo in each season (Zedler, 2003). Furthermore, both studies measured gas flux in a laboratory study rather than in the field. Field measurements allow researchers to examine the relationship between climate and GHG flux (Davis et al., 2010; Chuersuwan et al., 2014; Ricker et al., 2014).

GHG flux is influenced by many different factors, existing both in the soil and externally. The debate of whether wetlands serve as sources or sinks of GHG does not exclude vernal pools, which, while small and ephemeral in nature, are large in number (RIGIS, 2011). To what extent the emissions of these gases will vary across the range of saturations and inundations that occur within vernal pools is largely unknown. The small size of vernal pools actually benefits researchers, as it allows for focused studies of the impact of soil saturation on organic decomposition processes and GHG fluxes over short distances.

The purpose of this study was to investigate the relationships between hydrologic regime and key wetland processes. I examined the balance between inputs and outputs of carbon in vernal pool wetlands. I quantified leaf litter deposition rates throughout the vernal pools (Davis, 2001), as well as the bulk density and loss on ignition (LOI) in order to investigate soil as a sink for carbon (Nelson and Sommers, 1996; Hobson, 1998). However, in order to quantify the ability of the soil to serve as a carbon sink, it is important to also examine losses of carbon from the soil. I examined the rate of organic matter decomposition in the different hydrologic zones of the vernal pools. In order to do this, I replicated three common sources of organic matter; leaf litter, deadfall, and roots, and measured the decomposition that took place 
over time across a hydrologic gradient. These studies will provide insight into differences in carbon inputs and outputs between upland and wetland environments.

Furthermore, I was interested in determining whether the unique hydrologic and edaphic characteristics of vernal pools cause their $\mathrm{CO}_{2}, \mathrm{CH}_{4}$, and $\mathrm{N}_{2} \mathrm{O}$ fluxes to differ from those emitted by other wetland environments. I investigated the flux of three greenhouse gases, $\mathrm{CO}_{2}, \mathrm{CH}_{4}$ and $\mathrm{N}_{2} \mathrm{O}$ in the different vernal pool zones and examined the role that climate, hydrology, and landscape position plays in gas flux

processes. In addition, I compared $\mathrm{CO}_{2}$ flux to root density to estimate the ratio of heterotrophic to autotrophic respiration occurring in vernal pool soils. This comparison allowed for an appraisal of the magnitude by which each process influences $\mathrm{CO}_{2}$ flux (Ricker et al., 2014). These studies will provide a better understanding of carbon dynamics in vernal pool wetlands.

\section{MATERIALS AND METHODS}

\section{Quantifying Carbon Stocks}

Carbon stocks were quantified at each research plot along the three transects at each site (see Chapter 1 for descriptions of the study sites). Soil samples were collected by driving a sharpened aluminum tube $(60 \mathrm{~cm}$ long and $7.5 \mathrm{~cm}$ in diameter irrigation pipe) $50 \mathrm{~cm}$ into the soil and excavating the core from the soil. The tubes were capped in the field, moved to the lab, and frozen until they were described. Electric metal shears were used to open the cores once thawed, and morphological descriptions were made for each core (Schoeneberger et al., 2002), Samples were collected based on the master horizons present (i.e. O horizons, A horizons). Horizon 
thicknesses was recorded and all of the soil materials for each master horizon was sampled and weighed. Bulk density for each horizon was calculated by dividing the dry weight of the horizon by the horizon volume (cross-sectional area of the core times the horizon thickness) (Soil Survey Laboratory Staff, 2004). Total soil carbon stocks $\left(\mathrm{g} / \mathrm{m}^{2}\right)$ to $50 \mathrm{~cm}$ in the soil profile were calculated using estimated SOC content and bulk density and horizon thickness data (Homann and Grigal, 1996).

Estimates for the proportion of SOC in total SOM contents were obtained from a study by Davis (2001), which determined workable estimates based on soils of different drainage classes. For the purpose of this study, I used proportion estimates from the Carlisle (very poorly drained organic soils) for the only Histosol, and used Raypol estimates (poorly drained mineral soils) for the remainder of the basin soils. I also used Raypol estimates to calculate SOC in the transitional soils, and Windsor estimates (excessively drained sandy soils) to calculate SOC pools in the upland soils.

\section{$\underline{\text { Litterfall }}$}

Three plastic trays $(53.5 \mathrm{~cm} \times 27.5 \mathrm{~cm})$ were placed at each plot along the central transect of all vernal pools to collect litterfall. Leaf litter deposition was measured between the months of October and November of 2015. This selected sampling period is line with Ricker (2014), which reports that the majority of leaf litter fall occurs between the months of September and November in forested wetland environments. Leaves were collected in November, dried at $60^{\circ} \mathrm{C}$, and weighed in order to determine carbon contributions at the various hydrologic zones throughout the vernal pools. Carbon inputs were estimated assuming a concentration of $0.50 \mathrm{~g} \mathrm{C} \mathrm{g}^{-1}$ of leaf litter (Davis et al., 2010). 


\section{Organic Matter Decomposition}

Three methods were used to measure the relative rates of organic matter decomposition at the surface and subsurface along one transect at each site. Five replicate nylon mesh leaf-litter bags were filled with dried, pre-weighed leaves (Quercus alba, Quercus velutina, Acer rubrum) and secured at the soil surface in each zone. Five replicate pre-weighed northern white birch (Betula papyrifera) dowels (30 $\mathrm{cm}$ in length and $0.95 \mathrm{~cm}$ in diameter) were secured to the soil surface at each research plot along the same transect at the same time as the leaf litter bags. The bags and dowel rods were left on the soil surface from July 1 to September 30 in 2015 and from June 1 to August 31 in 2016. I calculated the number of growing degree days for each time span to identify any difference in energy in the soil system between the two years. Growing degree days is an index of soil heat that is based on air temperatures. This index is indicative of soil microbial activity and is helpful when investigating whether or not a shift in time frame influenced any apparent differences in overall decomposition. Growing degree days are calculated by averaging the minimum and maximum temperatures reported and subtracting the lowest reported temperature. Any day with a temperature higher than this calculated value is considered a growing degree day (Douglas and Rickman, 1992).

The leaf litter bags were retrieved, dried at $60^{\circ} \mathrm{C}$ and weighed in order to determine the loss of organic matter over time to determine decomposition rates (Capps et al., 2014). Rods were removed, washed, dried, and weighed in order to determine overall weight loss. Along all three transects, five pre-weighed replicate dowels were inserted vertically into the soil to a depth of $25 \mathrm{~cm}$ at each research plot 
in June of 2015, collected from the field three months later, and prepared in the same manner as the dowel rods placed on the soil surface.

\section{Greenhouse Gas Flux}

$\mathrm{CO}_{2}, \mathrm{CH}_{4}$, and $\mathrm{N}_{2} \mathrm{O}$ flux was measured using a closed chamber approach. Flux rates were measured at each research plot on the three transects at each site, providing data for each of the three hydrologic zones. Two cylindrical plastic chambers $(16 \mathrm{~cm}$ in height, $20 \mathrm{~cm}$ in diameter) were placed at each site and pushed approximately 2.5 $\mathrm{cm}$ into the soil. Using a $20 \mathrm{ml}$ gas-tight syringe, an initial gas sample was taken after securing the chamber's lid, which contained a rubber septum to allow for sampling, followed by samples taken 15 and 30 minutes after the initial sample. In order to mix the gases in the headspace of the chamber prior to sampling, the syringe was pumped three times. Measurements were taken monthly between August and November of 2015 and May and August of 2016. Between each month, the chambers were moved laterally throughout each zone. After sample collection, the syringe contents were immediately transferred into a $15 \mathrm{ml}$ evacuated tube (Amador and Azivinis, 2013). In the field, internal chamber temperatures were also measured when each gas sample was collected and averaged in order to obtain the average chamber temperature during the sampling period. Soil temperature at a depth of $5 \mathrm{~cm}$, and specific chamber volume $\left(\mathrm{m}^{3}\right)$ were recorded at each time interval of sample collection (Ricker et al., 2014; Waggoner, 2016).

$\mathrm{CO}_{2}, \mathrm{CH}_{4}$, and $\mathrm{N}_{2} \mathrm{O}$ concentrations were measured with a Shimadzu gas chromatograph and recorded in units of ppm (Altor and Mitsch, 2008).

Concentrations were plotted against time and fitted with a linear regression in order to 
calculate the $\mathrm{CO}_{2}$ flux rates. The mass of each gas present in the sampling chamber, or $\mathrm{n}$ (mol), was calculated using the Ideal Gas Law, $n=\mathrm{RT} / \mathrm{PV}$, where $n=\mathrm{mol} \mathrm{CO}_{2}$ per mol air, $\mathrm{R}=$ universal gas constant $(0.0821 \mathrm{~L}$ atm/mol $\mathrm{K}), \mathrm{T}=$ chamber internal temperature $(\mathrm{K}), \mathrm{P}=$ atmospheric pressure $(\mathrm{atm})$, and $\mathrm{V}=$ chamber volume $(\mathrm{L})$. The rate of GHG production per unit area was calculated using the slope of the best-fit line, cross-sectional area of the chamber, and volume of air in the chamber (Waggoner, 2016).

\section{Carbon Dioxide Respiration Partitioning}

The ratio of heterotrophic (microbial) to autotrophic (root) respiration was evaluated using root biomass/CO $\mathrm{CO}_{2}$ flux relationship (Ricker et al, 2014; ArchMiller and Samuelson, 2015). This method is based on the linear relationship between root biomass (independent variable) and total $\mathrm{CO}_{2}$ concentrations emitted from the soil (dependent variable). Based on this relationship, microbial respiration is assumed to be represented by the y-intercept of the linear regression model, and at this point, there is no root biomass present in the soil. Without root biomass, it is assumed that all of the $\mathrm{CO}_{2}$ respiration can be attributed solely to microbial activity (Kuzyakov, 2006). At the time of each gas sampling session, a root corer $(6.5 \mathrm{~cm}$ in diameter $)$ was used to collect soil samples of a known volume to a depth of $10 \mathrm{~cm}$. Samples were taken from the center of each cylindrical plastic chamber. The samples were transferred to the laboratory and air dried. Once dry, tweezers were used to remove all root biomass materials from the soil samples. Roots were washed with a calgon solution in order to remove any residual soil, air dried, and weighed. Total root biomass for each sample 
was plotted against the $\mathrm{CO}_{2}$ respiration rates in order to evaluate how much respiration can be attributed to roots versus microbial activity (Ricker et al., 2014).

\section{$\underline{\text { Hydrological Measurements }}$}

At each site, the depth to the water table was monitored and recorded four times per day via water table loggers in PVC wells installed at each plot along the central transect. Manual measurements of water table depths were taken monthly at each well on all three transects (Chapter 1). Monthly water table depths were plotted against $\mathrm{CO}_{2}, \mathrm{CH}_{4}$, and $\mathrm{N}_{2} \mathrm{O}$ flux rates in order investigate the relationship between soil hydrology and GHG emissions. Flux rates were also compared across the three hydrologic zones (Capps et al., 2014; Kuhn, 2015).

\section{Climate Data}

Weather data from the University of Rhode Island's long-term monitoring (at least 30 years) weather station (Kingston, RI) were obtained in order to learn of local air temperatures maximums and minimums and daily precipitation (Diamond et al., 2013). Surface soil temperature was measured by inserting a digital thermometer into the top $5 \mathrm{~cm}$ of the soil in each zone on the main transect at the time of gas sampling. These data were compared to the monthly variations between GHG fluxes in the vernal pools in order to investigate the relationship between climate and GHG flux (Mitsch et al., 2012; Chuersuwan et al., 2014). 


\section{RESULTS AND DISCUSSION}

\section{Carbon Stocks}

Soil carbon pools are a function of plant additions, such as roots, leaf litter, and deadfall, and the loss of that carbon through the process of decomposition (Bontti et al., 2000; Capps et al., 2014; Ricker et al., 2014). Average SOC pools in the upper 50 $\mathrm{cm}$ of the soils ranged from 8 to $11 \mathrm{~kg} \mathrm{~m}^{-2}$, with the upland having the average lowest value (Table 2.1). The mean SOC pool estimated in the upland zone $\left(8 \mathrm{~kg} \mathrm{~m}^{-2}\right)$ was very similar to the $9 \mathrm{~kg} \mathrm{~m}^{-2}$ that Davis et al. (2014) reported for Typic Udipsamments in southern New England. Increased soil wetness slows rates of organic matter decomposition such that wetter soils have greater SOC pools than drier soils (Zdruli et al., 1995; Davis et al., 2004). Thus, the basin and transitional zones had the largest pools. The basin soils had the greatest variations, ranging from 5.5 to $19 \mathrm{~kg} \mathrm{~m}^{-2}$. The EP basin soil was dominated by organic soil materials (Table 1.6) and all the SOC was stored in the organic horizons (Figure 2.1). Proportions of total SOC pools in the master horizons of the other soils varied among hydrologic zones across the sites. In general, A and B horizons held similar proportions of the total SOC, with the exception of the soils with buried A horizons (Figure 2.1), which had a greater proportion of the SOC stored in A horizons.

\section{$\underline{\text { Litterfall Additions and Decomposition }}$}

In temperate forests such as those in New England leaf litter is typically the largest source of carbon to the soils (Davis et al., 2004; Ricker et al, 2014). Leaf litter SOC inputs varied among zones and sites (Figure 2.2a). Mean SOC additions ranged from 58 to $149 \mathrm{~g} \mathrm{C} \mathrm{m}^{-2}$ in the basin zones, from $54 \mathrm{~g} \mathrm{C} \mathrm{m}^{-2}$ to $121 \mathrm{~g} \mathrm{C} \mathrm{m}^{-2}$ in the 
transitional zones, and from $40 \mathrm{~g} \mathrm{C} \mathrm{m}^{-2}$ to $129 \mathrm{~g} \mathrm{C} \mathrm{m}^{-2}$ in the upland zones. Ricker et al. (2014) measured leaf litter additions in southern New England forests and found that leaf litter additions averaged approximately $90 \mathrm{~g} \mathrm{C} \mathrm{m}^{-2}$ in the riparian zones and $100 \mathrm{~g} \mathrm{C} \mathrm{m}^{-2}$ in the upland zones during the months of October and November. These additions account for approximately $70 \%$ of upland annual additions and $80 \%$ of annual additions to riparian zones, suggesting that the additions of leaf litter that I measured represented most of the annual additions to the soils in these forested systems.

Microorganisms utilize the SOC found in organic matter such as leaf litter as an energy source driving organic matter decomposition. Litter bags were left on the soil surface from July through September in 2015 and from June through August in 2016 to study leaf litter decomposition. These periods represented the majority of the year where the microbial populations are the most active. Average litter loss in 2015 during this period ranged from 6 to $12 \mathrm{~g} \mathrm{C} \mathrm{m}^{-2}$ (Figure 2.2b), depending on the site and the location along the transect. These losses represent roughly $10 \%$ of the organic carbon that is added in the fall when most of the leaves drop from trees (Figure 2.2a). These data suggest that leaves that are newly lain on the soil surface have relatively slow initial decomposition rates relative to additions of carbon.

On average, in three out of the four study sites, basin zones exhibited the most leaf litter decomposition, followed by the transitional zone, with upland zones exhibiting the least decomposition. The average loss of mass from the leaves applied ranged from 10 to $18 \%$. Bags in the basin zone yielded the highest percent loss, ranging from an average of 13.5 to $19.2 \%$ mass lost after three months. Average leaf 
litter losses ranged from 10.2 to $15.8 \%$ in the transitional zones and from 10.1 to $18 \%$ in the upland zones (Figure 2.3). Several studies have utilized leaf litter compositions similar to those in my litter bags (broad-leaf hardwood trees such as Acer rubrum). MacLean and Wein (1978) investigated leaf litter decomposition during the span of one year in New Brunswick, Canada. During the first three months of their study (September, October, and November) less than 10\% of the mass was lost. Capps et al. (2014) studied leaf litter decomposition in New England vernal pools during the same months as my study and also found the highest decomposition occurring in the wettest zones. The loss in mass that they reported (30 to 60\%), however, was much more than what I observed.

Leaf litter decomposition rates were much lower in 2016 than those experienced during the previous year (Figure 2.3). Average losses ranged from 2.5 to $6.2 \%$ of the leaf litter's initial mass in the transition zone, 2.5 to $3.8 \%$ in basin zones, and from 1.5 to $5.3 \%$ in upland zones. One possibility for the difference in decomposition rates between years is the period during which the litter bags were deployed. Leaf litter bags were placed in the vernal pools a month later (July) in 2015 than in 2016. Records of growing degree days, however, were very similar (approximately 2500 growing degree days during both experiments) suggesting that a difference in heat energy in the soil system was not a strong contributor to the difference in decomposition between the two years (http://uspest.org/cgibin/ddmodel.us).

Another explanation for the differences in decomposition between years could be moisture content. Both Moore et al. (1999) and Austin and Vitousek (2000) 
reported increased decomposition of leaf litter and deadfall at the soil surface with increased precipitation. After precipitation occurs, the land surface has the highest probability of drying first. Due to the small surface area of the leaves, they hold minimal moisture. Because microorganisms and other soil fauna decompose organic matter more efficiently in moist conditions, precipitation plays an important role in decomposition processes. In 2015, the pools experienced approximately twice the amount of rainfall during the three month period than in 2016 (Figure 2.4). The substantial decrease in rainfall during the 2016 field season may have contributed to the overall lower amounts of organic matter decomposition.

I also studied organic matter decomposition using dowel rods placed at the surface and inserted into the soil $25 \mathrm{~cm}$ to simulate dead fall and root decomposition, respectively. These coarse $(1 \mathrm{~cm}$ in diameter) sources of organic carbon were left in the field for the same period as the leaves. In 2016 losses ranged from 1.3 to $3.2 \%$, with the highest percent mass loss produced by the dowels in the basin zone. On average, surface dowels lost between 0.1 and $0.6 \%$ of their original mass in the transitional zones, and between 0.3 and $3.4 \%$ in the upland zones (Figure 2.5). Wooden dowels secured at the soil surface in 2015 displayed trends similar to the 2016 studies. In 2015, surface dowels' mean loss ranged from 0.7 to $2.6 \%$ in the transitional zones and 1.8 to $2.6 \%$ in the upland zones (Figure 2.5). In the basin zone, one mean value was as high as $13.3 \%$ in the basin with the remaining three below $2.5 \%$ loss. Excluding the one high value, these losses fall in the range of values ( $<10 \%$ loss) reported by Austin and Vitousek (2000) for decomposition of dowels secured at the soil surface. 
Wooden dowels placed below the soil surface showed much higher losses due to decomposition than those at the surface (Figure 2.6). Ground dowels placed in the basin zone exhibited the lowest amount of decomposition in (on average, between 9.5 and $14 \%$ of mass lost) while the upland zone had the highest (on average, between 10.2 and $20.3 \%$ of mass lost). Transitional zones averaged between 9.1 and $18.9 \%$ loss (Figure 2.6). Mean ground dowel decomposition in all zones exceeded the losses observed by O'Lear et al. (1999), in which losses after 3 months did not exceed $10 \%$. A study by Bontti et al. (2009) investigated wooden dowel decomposition and encompassed both above- and below-ground decomposition by positioning the dowels vertically, with half buried and half existing above the soil surface. Even when including the potential for both methods of decomposition, losses did not exceed $10 \%$. One likely explanation for these differences is the differences in hydrological conditions between studies. Both took place in either forested or grassland environments; neither took place in dedicated wetlands.

Differences in trends revealed by above- and below-ground decomposition are likely attributed to differences in the amount of moisture maintained by organic substrates at the soil surface versus below the soil surface. Materials laid on the soil surface are directly exposed to wind and sunlight, while materials in the subsurface are shielded from these elements. These differences in exposure cause surface substrates to dry faster than subsurface substrates. Furthermore, subsurface materials are surrounded by soil, and thus the moisture maintained by these materials is augmented by the moisture held in the soil pore space. Conversely, surface materials are not entirely surrounded by the soil, meaning that they are not exposed to soil moisture 
content to the same extent as the subsurface materials. These differences suggest that ideal conditions for microorganisms at the soil surface differ from those for microorganisms below the surface.

Comparison of vernal pool subsurface hydrology with organic matter decomposition trended toward significance in 2015 for leaf litter $(\mathrm{p}=0.06)$ and ground dowel losses $(\mathrm{p}=0.07)$. Leaf litter decomposition in 2015 decreased as the water table receded further below the surface (Table 2.2). While a comparison of surface dowels in 2015 and 2016 and leaf litter decomposition in 2016 to water table levels did not yield significant results, the data displayed a downward trend similar to the other experiment (Table 2.2). Conversely, the decomposition of dowels placed below the soil surface increased as the water table receded further from the soil surface (Table 2.2). Soil saturation results in an anaerobic soil environment, which inhibits microbial decomposition, overall slowing organic matter decomposition rates in wetlands (Whiting and Chanton, 2001; Altor and Mitsch, 2008). Thus, in the basin where the water table levels were the highest, decomposition was the lowest.

The question remains why would the ground dowels show less decomposition in the basin but the surface dowels and leaves in 2015 show greater decomposition in the basin. The higher mean surface decomposition rates exhibited by the basin zone in 2015 could be attributed to the greater likelihood of surface water to accumulate in the basin compared to the transitional and upland zones. Even if this accumulation did not result in surface inundation, the depressional nature of vernal pools would result in the basin being the wettest zone. Increased surficial moisture may have augmented the physical, chemical, and microbial processes responsible for decomposition, ultimately 
leading to higher percent losses in the wetter vernal pool zones. The previously established inclination for surface substrates to dry more readily than subsurface substrates suggest that basin hydrology facilitated ideal moisture levels for microorganisms at the soil surface.

Conversely, ground dowel decomposition was highest in the upland zone in three out of the four study sites (Figure 2.6). As discussed in Chapter 1, the upland zones possessed the only soils that did not meet the saturating conditions necessary to be considered a hydric soil at any point during the study. Aerobic soil conditions provide ample oxygen diffusion for microorganisms, serving as an environment that facilitates quick organic matter decomposition (Kristensen et al., 1995). Soils that are too dry may stress the microorganisms and impede decomposition, as some moisture is necessary to fuel these processes (Davidson and Janssens, 2006). Ground dowel decomposition increased as the soil environment became increasingly aerobic, creating a more favorable environment for the microorganisms. As previously discussed, dowels secured below the soil surface are more inclined to hold onto moisture than organic materials at the surface. Because of this, ground dowels in the basin were likely saturated, resulting in anaerobic conditions and the inhibition of microbial decomposition. On the other hand, organic materials at the surface dried more readily, facilitating moist conditions rather than saturated conditions, and providing the ideal amount of moisture for the microorganisms. Comparison of above- and below-ground decomposition with hydrology affirms the strength of the relationship between field moisture conditions and the efficiency of microorganisms. 
Differences in decomposition between leaf litter and surface dowels can be attributed to differences in their carbon to nitrogen ratios $(\mathrm{C}: \mathrm{N})$. On average, broadleaf foliage has a $\mathrm{C}: \mathrm{N}$ ratio of $35: 1$, while dowels, have a ratio of approximately 100:1 (Wade and Fay, 1989; McGroddy et al., 2004). The C:N ratio determines how easy it is for microorganisms to decompose organic matter (Brinson et al., 1981). A $\mathrm{C}: \mathrm{N}$ ratio of 30:1 readily facilitates decomposition (USDA-NRCS, 2011). Because leaves have a $\mathrm{C}: \mathrm{N}$ ratio much closer to this ideal value than wooden dowels, leaves tend to decompose more readily. Typically, wooden dowels also have higher lignin contents than leaf litter. Lignin is a material located in plant cell walls that provide the plant with woodiness and rigidity. Materials with higher lignin contents are often associated with larger C:N ratios. Bontti et al. (2009) investigated the relationship between lignin and organic matter decomposition and discovered that increased lignin contents drive decomposition processes. Substrate surface area also influences decomposition rates (Jackson et al., 1997). The surface area of one wooden dowel is approximately equivalent to that of one leaf. Because each litter bag contained $10 \mathrm{~g}$ of leaves, the surface area available for decomposition was much larger than that available on a single wooden dowel. This increased surface area may have contributed to the heightened decomposition exhibited by the leaf litter.

\section{$\underline{\text { Greenhouse Gas Flux }}$}

\section{Carbon Dioxide}

The most common GHG of concern for global warming are $\mathrm{CO}_{2}, \mathrm{CH}_{4}$, and $\mathrm{N}_{2} \mathrm{O}$ (Altor and Mitsch, 2008; Moseman-Valtierra et al., 2011). I measured each of these gases monthly during the months of August through November in 2015 and May 
through August in 2016. Simple linear regression analyses between $\mathrm{CO}_{2}$ flux and soil temperature were used to evaluate the influence that the soil environment has on the mechanisms responsible for $\mathrm{CO}_{2}$ flux. There was a significant correlation between soil temperature and $\mathrm{CO}_{2}$ flux in all of the study sites (Table 2.3; $\mathrm{p}<0.001$ ). In all vernal pools, as soil temperature increased, $\mathrm{CO}_{2}$ flux also increased (Table 2.3). Similar increases in respiration were reported by Reth et al. (2005), Davis et al. (2010), and Ricker et al. (2014). Warm soil environments encourage both microbial activity and plant growth, which are the primary mechanisms driving soil respiration. Thus, increased atmospheric temperatures resulting from climate change may also lead to increased $\mathrm{CO}_{2}$ emissions.

Both soil moisture and soil temperature affect soil respiration (Kuzyakov, 2005; Davis et al., 2010; Ricker et al., 2014). The relationship between soil moisture, soil temperature, and soil respiration is very complex. Heterotrophic and autotrophic respiration is inhibited when the soil is saturated resulting in anaerobic conditions. Respiration is also inhibited when the soil is too dry, as excessively dry conditions induce stress on the microbial and plant communities. I measured soil saturation, but it should be noted that depth of the water table gives some indication of the moisture status of the soil. Linear regression analysis revealed a significant interaction between water table depth and $\mathrm{CO}_{2}$ flux in one vernal pool $(\mathrm{GS} ; \mathrm{p}=0.026)$. Results trended towards significance in one other vernal pool site $(\mathrm{EP} ; \mathrm{p}<0.1)$. At these sites, as the distance from the soil surface to the water table increased, $\mathrm{CO}_{2}$ flux increased, as well (Figure 2.7). These results suggest that as the water table receded further below the soil surface, the aerobic conditions encouraged soil respiration. Similar trends were 
apparent when investigating below-ground organic matter decomposition; decomposition increased with increased depth between the soil surface and the water table (highest decomposition was reported in the driest soils). While there are multiple processes that contribute to soil respiration, these similar trends support the current belief that microbial respiration is favored in unsaturated soil environments (Inglett et al., 2012; Kuhn, 2015). All basin zone soils were saturated within the upper $25 \mathrm{~cm}$ at least during the months of May and June, while one site extended these saturated conditions through the month of July (CAR 3). The upper saturation of soils in the transitional zone varied as well, ranging from 1 to 2 months (Figure 2.8). Further investigations of $\mathrm{CO}_{2}$ flux emitted during months when the upper portion of the soil exhibits anaerobic conditions could provide a more accurate assessment of differences between aerobic and anaerobic respiration.

Analysis of $\mathrm{CO}_{2}$ flux across all study sites revealed a significant relationship between zone and flux $\left(\mathrm{p}=0.03\right.$; Table 2.4). Within CAR 3, $\mathrm{CO}_{2}$ flux also varied significantly by hydrologic zone $(\mathrm{p}<0.001)$. In both of these comparisons, the transitional zone produced a significantly greater $\mathrm{CO}_{2}$ flux than the basin zone. Although there was no significant difference between basin flux and upland flux, the increased flux exhibited by the drier transitional zone in comparison with the wetter basin zone supports the relationship suggested by linear regression analysis of hydrology versus subsurface organic matter decomposition; decomposition increased in drier soils. The literature offers contradicting evidence regarding the relationship between hydrology and soil respiration. For example, Davis et al. (2010) investigated soil respiration in seasonally saturated versus better drained upland soil environments 
and found that the very poorly drained soils emitted the lowest $\mathrm{CO}_{2}$ fluxes overall. In contrast, Ricker et al. (2014) found no significant difference in $\mathrm{CO}_{2}$ flux when comparing poorly-drained wetland and upland environments. Raich and Schlesinger (1992) suggested that the specific type of wetland determines whether wetlands or non-wetlands produce more $\mathrm{CO}_{2}$ to the atmosphere. Such contrasting evidence merits further investigation into the contribution of $\mathrm{CO}_{2}$ emissions from wetlands into the atmosphere.

Although soil temperature is the main factor influencing soil respiration (Kicklighter et al. 1994), soil moisture also influences soil respiration (Davis et al., 2010). When fit with a multiple regression, water table level and soil temperature were significantly correlated to $\mathrm{CO}_{2}$ flux in all vernal pool study sites $(\mathrm{p}<0.001$; Table 2.3). The $\mathrm{R}^{2}$ values, however, increased very little or not at all when compared to just the temperature data, indicating that for these two factors soil temperature explains more of the variability in $\mathrm{CO}_{2}$ flux. Similarly, Schlentiner and Van Cleve (1984) and Davis et al. (2010) found a stronger relationship between $\mathrm{CO}_{2}$ flux and soil temperature than with soil moisture. For example, Davis et al. (2010) found that 72$88 \%$ of $\mathrm{CO}_{2}$ flux could be attributed to soil temperature, but when analyzing soil moisture effects only $18-43 \%$ of the flux could be explained by soil moisture.

$\mathrm{CO}_{2}$ flux varied among the pools and their respective zones (Figure 2.9). Mean monthly $\mathrm{CO}_{2}$ flux ranged from 5 to $22 \mu$ mole $\mathrm{m}^{-2} \mathrm{~min}^{-1}$ (Figure 2.9). These rates are very similar to those reported by Waggoner (2016), after which the $\mathrm{CO}_{2}$ flux sampling and analysis methods for my study were modeled. This method uses a closed chamber and samples are manually obtained using a syringe. For comparison, 
Ricker et al. (2014) reported much larger fluxes than I observed, reaching upwards of $480 \mu$ mole $\mathrm{m}^{-2} \mathrm{~min}^{-1}$. These studies were in forested wetlands and uplands, an environment similar to my own study. Moseman-Valtierra et al. (2011) investigated soil respiration rates in a marsh environment and reported flux values similar to Ricker et al. (2014). One potential explanation for these differences in values is a difference in methodology. Ricker et al. (2014) and Moseman-Valtierra et al. (2011) both used an automated gas samplers when measuring soil flux. These samplers utilize a pump that forcefully mixes gases in the chamber headspace before sampling. Although I did use the syringe to mix the gases in the chamber before withdrawing my sample, it is possible that the volume of the syringe in comparison to the volume of the chamber did not provide adequate mixing, resulting in a lesser concentration being withdrawn. The significant relationships between $\mathrm{CO}_{2}$ and soil temperature (Table 2.3) suggest that the methods I used for gas sampling and analysis provide at a minimum a relative measure of the controlling processes in regard to $\mathrm{CO}_{2}$ flux in vernal pools.

For understanding SOC sinks and sources, it is critical to identify whether the source of $\mathrm{CO}_{2}$ from the soil is a function of microbial decomposition of SOC or root respiration. Thus, I utilized a linear regression technique relating root biomass to $\mathrm{CO}_{2}$ flux to estimate root respiration (Ricker, 2014). Although the correlations were generally very weak (all $\mathrm{R}^{2}$ values $<0.5$; Table 2.5 ), the analysis suggested that root respiration accounted for $<40 \%$ of the $\mathrm{CO}_{2}$ flux (Table 2.6). The exception was the basin average in October which was twice as much (78\%) as the next highest value (39\%). If this high value is excluded, average root respiration values are $<30 \%$ suggesting that microbial decomposition is the dominant process toward $\mathrm{CO}_{2}$ efflux. 
Root respiration varied significantly with hydrologic zone during the months of September, October, and November ( $\mathrm{p}<0.04$; Table 2.7). In September, percent root respiration was significantly higher in the upland zone than the transitional zone, while in October, percent root respiration was significantly higher in the basin zone than in the transitional and upland zones. Percent root respiration was also significantly higher in the basin zone than in the transitional zone during the month of November (Table 2.6). The varied results and the low correlation values of the root/respiration sheds little light on the extent that hydrologic zone controls root respiration. Hanson et al. (2000) reported that the contribution of root respiration to overall $\mathrm{CO}_{2}$ flux is heavily dependent on vegetation type and season. While vegetation analyses revealed similar trends in type in the hydrologic zones and percent cover across all study sites (Figure 1.5), the amount of variability among sites suggests that relating vegetation effects to root respiration is beyond the scope of my study. Likewise, further investigation evaluating root versus microbial respiration in vernal pools by season would be helpful in ascertaining a more accurate relationship between these two pathways.

\section{Methane}

$\mathrm{CH}_{4}$ is considered to be one of the most potent GHG (Altor and Mitsch, 2008; Moseman-Valtierra et al., 2011). Vernal pool hydrology was significantly correlated to $\mathrm{CH}_{4}$ flux in all study sites $(\mathrm{p}<0.003)$. All zones of CAR 2 and EP exhibited net consumption (negative flux) of $\mathrm{CH}_{4}$ during all sampling months except for May and June. During these months, the basin zones exhibited net production (positive flux) of $\mathrm{CH}_{4}$. CAR 3 and $\mathrm{GS}$ followed the same trends in the basin zones; the only variations 
consisted of several small positive $\mathrm{CH}_{4}$ fluxes observed outside of the aforementioned months (Figure 2.10). A linear regression analysis confirmed the role that hydrology plays in $\mathrm{CH}_{4}$ flux processes. In all vernal pools, $\mathrm{CH}_{4}$ flux decreased as water table levels receded farther below the soil surface (Table 2.8).

$\mathrm{CH}_{4}$ flux varied significantly with hydrologic zone in all of the vernal pool study sites when analyzed via a one-way ANOVA both individually ( $\mathrm{p}<0.04)$ and across all pools ( $\mathrm{p}<0.001$; Table 2.9). Flux was significantly higher in the basin zone than the upland zone at all sites, and was significantly higher in the basin zone than the transitional zone in three out of the four sites (results trended towards significance in GS). This can be attributed to the nature of methanogenesis as an anaerobic process. Methanogenesis only occurs in areas of very low redox potential which is facilitated by periods of extended saturation (Kuhn, 2015) such as vernal pool basins.

Methanogenesis occurs when $\mathrm{CO}_{2}$, which is not thermodynamically favored by microorganisms, is the electron acceptor primarily available for redox reactions. Different pools of microorganisms are responsible for the various carbon dynamics involved in wetland environments. Specifically, once the organic matter in the vernal pools are broken down, separate methanogenic microorganisms (methanogens) utilize hydrogen and acetate in order to respire, resulting in $\mathrm{CH}_{4}$ flux into the atmosphere. The only positive $\mathrm{CH}_{4}$ flux was observed in the wettest zone, suggesting increased pools of methanogens and of the microorganisms responsible for the products of decomposition in the basin zones. May and June were the only months sampled during which basin zones were inundated with water, allowing anaerobic conditions to prevail in the soil. When methanogens have to compete with aerobic microorganisms 
for organic substrates, methanogenesis is suppressed, explaining why positive fluxes were only present in flooded, anaerobic environments of low redox potential (Segers, 1998; Whiting and Chanton, 2001). Previous analyses suggested that subsurface organic matter decomposition rates are slowest in the wettest zones. It is possible that the activity of detritivores, or decomposing microorganisms, is heightened in aerobic environments. Further analyses investigating the microbial communities and activity in vernal pool basin versus upland environments in pools could provide insight into the reasoning behind differences in decomposition and methanogenesis efficiency.

The mean negative flux values indicate that during those months, $\mathrm{CH}_{4}$ was being absorbed by the soil over time, rather than emitted. The amount of $\mathrm{CH}_{4}$ removed from the atmosphere by soils is estimated at $30 \mathrm{Tg}$ per year. Methane absorption is common in soils dominated by an aerobic environment. Such absorption is a process commonly associated with forested soils (Kagotani et al., 2001). Aerobic upland soils serve as ideal environments for $\mathrm{CH}_{4}$ absorption. Although transitional zone soils are wetter than upland soils and are not primarily aerobic, methane absorption was also noted (Figure 2.10) suggesting that methanogenesis only occurs in the wettest areas of the vernal pools.

Mean positive $\mathrm{CH}_{4}$ emissions during May and June amounted to 0.02 to 0.03 $\mu$ mole $\mathrm{m}^{-2} \mathrm{~min}^{-1}$ in the basin zones. These values are similar to those reported by Kang and Freeman (2002), who studied $\mathrm{CH}_{4}$ flux in a freshwater bog. They also utilized a manual closed chamber approach and reported emissions ranging from 0.009 to $0.37 \mu$ mole $\mathrm{m}^{-2} \mathrm{~min}^{-1}$. My reported values are somewhat lower than those reported by Moseman-Valtierra et al. (2011), which ranged from 0.05 to $1.5 \mu$ mole $\mathrm{m}^{-2} \mathrm{~min}^{-1}$ in 
a salt marsh environment. Altor and Mitsch (2008) investigated $\mathrm{CH}_{4}$ production in soils experiencing different degrees of inundation, and found that intermittentlyflooded soils (which are most similar with the ephemeral flooding experienced in vernal pool basins) produced approximately $1 \mu$ mole $\mathrm{m}^{-2} \mathrm{~min}^{-1}$. These gas flux values were obtained from a mesocosm and microcosm experiments, which is a much more controlled environment and experienced more concentrated periods of flooding and subsidence. The difference in experimental design may have contributed to these differences in values. Despite the differences, when investigating $\mathrm{CH}_{4}$ flux in hydric versus non-hydric soils, Altor and Mitsch found that hydric soils produced significantly more $\mathrm{CH}_{4}$, which was the case in my study, as well. Kuhn (2015) measured $\mathrm{CH}_{4}$ flux based on grams of soil rather than on an area basis, so exact quantities of flux could not be compared. However, the study compared flux in the same three zones as I used and found the highest production in the basin zones. The positive $\mathrm{CH}_{4}$ flux emitted by the basin zones may have_implications on climate change, as $\mathrm{CH}_{4}$ as a greenhouse gas has a potency of 25 times that of $\mathrm{CO}_{2}$.

\section{Nitrous Oxide}

$\mathrm{N}_{2} \mathrm{O}$ is produced in wetland soils through the process of denitrification, in which microorganisms reduce nitrogen oxides into nitrogen gases. Specifically, $\mathrm{N}_{2} \mathrm{O}$ is an intermediate gas produced when denitrification does not proceed to completion (Bernhard, 2010). In this process, a source of nitrate $\left(\mathrm{NO}_{3}{ }^{-}\right)$is necessary as an electron acceptor during the microbial metabolism (Capps et al., 2014). Because my sites are located in protected management areas, immediate sources of $\mathrm{NO}_{3}{ }^{-}$, such as fertilizer, industrial waste, and urban drainage, may not be readily available. This may 
be why little $\mathrm{N}_{2} \mathrm{O}$ appeared to be emitted to the atmosphere from the vernal pools (Figure 2.11). Other processes, however, also control how much $\mathrm{N}_{2} \mathrm{O}$ is released, including nitrification, nitrifier denitrification, and coupled nitrificationdenitrification (Moseman-Valiterra et al., 2011). These processes would likely require an oxic-anoxic interface to oxidize ammonium to nitrate, which are typically present at the top of the water table. Since I did not measure $\mathrm{NO}_{3}{ }^{-}$concentrations, whether $\mathrm{N}_{2} \mathrm{O}$ release was limited by the levels of $\mathrm{NO}_{3}{ }^{-}$or incomplete processing of the $\mathrm{N}$ is still a question. When fit with a linear regression, only one vernal pool (CAR 3) reflected a significant correlation between water table level and $\mathrm{N}_{2} \mathrm{O}$ flux $(\mathrm{p}=0.04)$. At CAR 3, $\mathrm{N}_{2} \mathrm{O}$ flux into the atmosphere decreased as the distance from the soil surface to the water table increased. My results contrast with those reported by Capps et al. (2014), who quantified denitrification in vernal pool basin, transitional, and upland soils. In their study, upland zones consistently produced lower amounts of $\mathrm{N}_{2} \mathrm{O}$ than soils from the wetter zones. In my study, mean $\mathrm{N}_{2} \mathrm{O}$ ranged from -0.009 to $0.008 \mu$ mole $\mathrm{m}^{-2} \mathrm{~min}^{-}$ 1. These fluxes are significantly lower than those reported by Chuersuwan et al. (2013), who observed mean wetland $\mathrm{N}_{2} \mathrm{O}$ fluxes of $1 \mu$ mole $\mathrm{m}^{-2} \mathrm{~min}^{-1}$. MosemanValtierra et al. (2011) found many intrinsic $\mathrm{N}_{2} \mathrm{O}$ flux values to be nonsignificant (net of 0) in their salt marsh study sites. After applying several experimental manipulations to their plots, such as different lighting regimes and $\mathrm{NO}_{3}{ }^{-}$ enhancements, positive flux rates were detectable. Implementing similar experimental manipulations may serve as a more beneficial method of determining denitrification contributions of vernal pool soils, especially because of the lack of $\mathrm{NO}_{3}{ }^{-}$sources available in many Rhode Island vernal pools. 


\section{SUMMARY AND CONCLUSIONS}

Wetland soils store much of the earth's terrestrial carbon pool, and thus their soil carbon budget has been increasingly investigated within the scientific community in an attempt to mitigate the impacts of global climate change. In this study, I evaluated the relationships between hydrologic regime and key wetland processes by examining the balance between inputs and outputs of carbon in vernal pool wetlands. Soil carbon pools varied across the three hydrologic zones. On average, upland zones possessed the smallest SOC pools in the upper $50 \mathrm{~cm}$ of the soil, while the basin and transitional zones stored about $20 \%$ more SOC. Differences in these pools were likely due to the extended saturation in the basin and transitional soils, which facilitates greater accumulation of SOC by slowing organic matter decomposition. Proportions of the total SOC were similar in the A and B horizons, with the exception of the soils with buried A horizons which had a greater proportion of the SOC stored in A horizons.

The carbon pool in a soil is a function of additions such as leaves, sticks, and roots and the rate at which those additions are decomposed and the carbon released as $\mathrm{CO}_{2}$. Comparisons of average leaf litter losses in 2015 to the SOC additions suggest that leaves that are newly deposited on the soil surface have relatively slow initial decomposition rates relative to SOC additions. Average decomposition rates of leaf litter and wooden dowels on the soil surface were much higher in 2015 than in 2016, likely because of the increased precipitation experienced by the vernal pools in 2015 . Comparison of hydrology and decomposition trended toward significance in leaf litter and subsurface wooden dowel decomposition. Above-ground decomposition 
increased as the water table level became closer to the soil surface, while belowground decomposition increased as soils became more aerobic. Because substrates at the soil surface dry more readily than substrates below the surface, these results suggest that microbial decomposition is favored at moist field conditions, which were achieved at the surface in the basin zone and below the surface in the upland zone. Depending on environmental conditions, microorganisms will respire either aerobically (via the tricarboxylic acid cycle) or anaerobically (via fermentation). Aerobic respiration is typically a faster process than anaerobic respiration, supporting evidence obtained in this study that subsurface organic matter decomposition occurs at faster rates in aerobic environments (upland) than in anaerobic environments (basin). In both years, the greater amount of decomposition experienced by the leaf litter than the wooden dowels affirms the important roles that $\mathrm{C}: \mathrm{N}$ ratios and surface areas play in decomposition processes.

Because of its nature as a potent GHG, understanding $\mathrm{CO}_{2}$ flux dynamics is critical at a time when climate change threatens the environment. In order to evaluate these dynamics, I monitored GHG flux in the three hydrologic zones of the vernal pool. As the Earth's atmosphere warms, soil temperature will increase as well, potentially leading to increased $\mathrm{CO}_{2}$ emissions. Soil respiration was significantly correlated with soil temperature; increases in soil temperature resulted in increases in $\mathrm{CO}_{2}$ flux. Typically, as soil temperature increases, water table levels recede lower below the soil surface. Analysis of $\mathrm{CO}_{2}$ flux as compared to vernal pool hydrology and hydrologic zone suggest that soil respiration increases as soils become increasingly aerobic environments. In general, approximately $35 \%$ of $\mathrm{CO}_{2}$ flux or less 
could be attributed to root respiration. Partitionment of microbial and root respiration suggest that microbial decomposition is the driving process behind soil respiration. Results among different hydrologic zones shed little light on the extent to which hydrology influences root respiration.

$\mathrm{CH}_{4}$ flux was significantly influenced by vernal pool hydrology; $\mathrm{CH}_{4}$ fluxes were highest in the basin zones and decreased as the water tables dropped further below the soil surface. The saturated soils present in the basin zones facilitated ideal environments for methanogenesis to occur. Other than in the basin zones during the wettest months of the study, methanogenesis was suppressed and $\mathrm{CH}_{4}$ was consistently absorbed into the soil. The wetting and drying cycles of vernal pools wetlands means that it is not a consistent source of $\mathrm{CH}_{4}$; however, fluxes are present during certain times of the year. Quantifying $\mathrm{CH}_{4}$ emission in wetlands is critical at a time when climate change threatens the environment, as $\mathrm{CH}_{4}$ has a potency of 25 times that of $\mathrm{CO}_{2}$. Vernal pools emitted very little amounts of $\mathrm{N}_{2} \mathrm{O}$, likely due to the limited inputs of $\mathrm{NO}_{3}{ }^{-}$available in the sites. 
Table 2.1. Total SOC pools in the upper $50 \mathrm{~cm}$ of each hydrologic zone across all study sites.

\begin{tabular}{lcc}
\hline Pool & Zone & $\begin{array}{c}\text { Total SOC } \\
\left(\mathrm{kg} / \mathrm{m}^{-2}\right)\end{array}$ \\
\hline CAR 2 & Basin & 9.6 \\
CAR 3 & Basin & 5.5 \\
EP & Basin & 19 \\
GS & Basin & 11 \\
Mean & & $11(6)$ \\
\hline CAR 2 & Transitional & 9.0 \\
CAR 3 & Transitional & 10 \\
EP & Transitional & 13 \\
GS & Transitional & 12 \\
Mean & & $11(2)$ \\
\hline CAR 2 & Upland & 9.4 \\
CAR 3 & Upland & 7.1 \\
EP & Upland & 4.4 \\
GS & Upland & 10 \\
Mean & & $8(3)$ \\
\hline *STD (\%) in parentheses &
\end{tabular}


Table 2.2. Regression analysis of organic matter decomposition compared to the water table level during the 2015 and 2016 field seasons.

\begin{tabular}{|c|c|c|c|c|c|c|c|c|}
\hline \multirow[b]{2}{*}{ Substrate } & \multicolumn{2}{|l|}{2015} & \multicolumn{6}{|c|}{2016} \\
\hline & Equation & $\mathrm{n}$ & $\mathrm{R}^{2}$ & p-value & Equation & $\mathrm{n}$ & $\mathrm{R}^{2}$ & $\mathrm{p}$-value \\
\hline $\begin{array}{l}\text { Leaf litter } \\
\text { Wooden dowels }\end{array}$ & $y=-0.0463 x+18.815$ & 12 & 0.31 & 0.061 & $y=-0.0082 x+4.11$ & 12 & 0.074 & 0.391 \\
\hline $\begin{array}{l}\text { (surface) } \\
\text { Wooden dowels }\end{array}$ & $y=-0.0345 x+5.8744$ & 12 & 0.14 & 0.230 & $y=-0.0074 x+1.826$ & 12 & 0.096 & 0.326 \\
\hline (subsurface) & $y=0.0573 x+8.4211$ & 12 & 0.2982 & 0.066 & & & & \\
\hline
\end{tabular}


Table 2.3. Summaries of a single regression analysis comparing soil temperature and soil respiration ("Single") and a multiple regression analysis comparing soil temperature, water table level, and soil respiration ("Multiple").

\begin{tabular}{ccc|ccc|ccc}
\hline Pool & $\begin{array}{c}\text { Mean } \mathrm{CO}_{2} \text { Flux } \\
\left(\mu \mathrm{mole} / \mathrm{m}^{2} / \mathrm{min}\right)\end{array}$ & $\mathrm{STD}$ & $\mathrm{n}$ & $\begin{array}{c}\mathrm{R}^{2} \\
(\text { Single })\end{array}$ & $\begin{array}{c}\mathrm{p} \text {-value } \\
(\text { Single })\end{array}$ & $\mathrm{n}$ & $\begin{array}{c}\mathrm{R}^{2} \\
(\text { Multiple) }\end{array}$ & $\begin{array}{c}\mathrm{p} \text {-value } \\
(\text { Multiple })\end{array}$ \\
\hline CAR 2 & 11.55 & 7.49 & 48 & 0.41 & $<0.001$ & 48 & 0.42 & $<0.001$ \\
CAR 3 & 11.07 & 6.25 & 48 & 0.24 & $<0.001$ & 48 & 0.24 & 0.002 \\
EP & 13.89 & 5.58 & 48 & 0.43 & $<0.001$ & 48 & 0.48 & $<0.001$ \\
GS & 13.76 & 6.92 & 47 & 0.32 & $<0.001$ & 47 & 0.36 & $<0.001$
\end{tabular}

Table 2.4. Non-parametric one-way ANOVA analysis of hydrologic zone vs. $\mathrm{CO}_{2}$ flux (Kruskal-Wallis test).

\begin{tabular}{llll}
\hline Pool & $\mathrm{n}$ & H-statistic & $\mathrm{p}$-value \\
\hline All & 189 & 6.81 & 0.033 \\
CAR 2 & 46 & 3.92 & 0.141 \\
CAR 3 & 48 & 9.38 & 0.009 \\
EP & 48 & 1.25 & 0.536 \\
GS & 47 & 0.02 & 0.990
\end{tabular}


Table 2.5. Regression analysis comparing root density and soil respiration during the 2015 field season.

\begin{tabular}{|c|c|c|c|c|c|c|c|c|c|c|c|c|}
\hline \multicolumn{4}{|c|}{ Basin } & \multicolumn{4}{|c|}{ Transitional } & \multicolumn{4}{|c|}{ Upland } & \multirow[b]{2}{*}{ p-value } \\
\hline Month & Equation & $\mathrm{n}$ & $\mathrm{R}^{2}$ & p-value & Equation & $\mathrm{n}$ & $\mathrm{R}^{2}$ & p-value & Equation & $\mathrm{n}$ & $\mathrm{R}^{2}$ & \\
\hline August & $y=14.858 x+13.092$ & 7 & 0.15 & 0.388 & $y=13.035 x+13.301$ & 8 & 0.29 & 0.166 & $y=9.1251 x+10.803$ & 7 & 0.34 & 0.175 \\
\hline September & $y=4.1008 x+9.4359$ & 8 & 0.12 & 0.406 & $y=-5.1567 x+13.816$ & 8 & 0.16 & 0.333 & $y=3.857 x+5.6144$ & 8 & 0.23 & 0.227 \\
\hline October & $y=18.429 x+1.8971$ & 8 & 0.48 & 0.056 & $y=8.265 x+12.924$ & 7 & 0.08 & 0.550 & $y=18.154 x+5.5761$ & 8 & 0.4 & 0.093 \\
\hline November & $y=1.6812 x+3.3268$ & 7 & 0.26 & 0.253 & $y=-0.9106 x+9.5152$ & 7 & 0.01 & 0.827 & $y=0.321 x+7.3498$ & 7 & 0.002 & 0.924 \\
\hline
\end{tabular}

U Table 2.6. Estimated percentage of mean root respiration out of total soil respiration. Estimates were made using the linear regression technique.

\begin{tabular}{lccc}
\hline & Basin Zone & Transitional Zone & Upland Zone \\
\hline \multicolumn{1}{c}{ Month } & $\begin{array}{c}\text { Mean Root } \\
\text { Respiration }(\%)^{*}\end{array}$ & $\begin{array}{c}\text { Mean Root } \\
\text { Respiration }(\%)^{*}\end{array}$ & $\begin{array}{c}\text { Mean Root } \\
\text { Respiration }(\%)^{*}\end{array}$ \\
\hline August & $20(19)$ & $21(16)$ & $28(23)$ \\
September & $15(19)$ & $3(9)$ & $25(25)$ \\
October & $78(12)$ & $26(25)$ & $39(29)$ \\
November & $24(18)$ & $5(9)$ & $10(11)$ \\
\hline Mean & $34(29)$ & $14(11)$ & $26(12)$ \\
\hline
\end{tabular}

*STD (\%) in parentheses 
Table 2.7. Non-parametric one-way ANOVA analysis of hydrologic zone vs. percent root respiration in 2015 (Kruskal-Wallis test).

\begin{tabular}{lccc}
\hline Month & $\mathrm{n}$ & F-statistic & $\mathrm{p}$-value \\
\hline August & 22 & 0.823 & 0.663 \\
September & 24 & 7.41 & 0.0247 \\
October & 23 & 12.9 & 0.0016 \\
November & 21 & 6.44 & 0.0399
\end{tabular}


Table 2.8. Regression analysis comparing $\mathrm{CH}_{4}$ flux to water table level.

\begin{tabular}{cccccc}
\hline Pool & $\begin{array}{c}\text { Mean } \mathrm{CH}_{4} \text { Flux } \\
\left(\mu \mathrm{mole} / \mathrm{m}^{2} / \mathrm{min}\right)\end{array}$ & $\mathrm{STD}$ & Equation & $\mathrm{R}^{2}$ & $\mathrm{p}$-value \\
\hline CAR 2 & -0.07 & 0.21 & $\mathrm{y}=-0.0029 \mathrm{x}+0.1564$ & 0.48 & $<0.001$ \\
CAR 3 & -0.08 & 0.19 & $\mathrm{y}=-0.0028 \mathrm{x}+0.1315$ & 0.53 & $<0.001$ \\
EP & -0.02 & 0.33 & $\mathrm{y}=-0.0028 \mathrm{x}+0.1828$ & 0.21 & 0.003 \\
GS & -0.06 & 0.12 & $\mathrm{y}=-0.0017 \mathrm{x}+0.0817$ & 0.40 & $<0.001$
\end{tabular}

Table 2.9. One-way ANOVA analysis of hydrologic zone vs. $\mathrm{CH}_{4}$ flux.

\begin{tabular}{lccc}
\hline Pool & $\mathrm{n}$ & F-statistic & $\mathrm{p}$-value \\
\hline All & 153 & 39.4 & $<0.001$ \\
CAR 2 & 38 & 14.9 & $<0.001$ \\
CAR 3 & 37 & 29.3 & $<0.001$ \\
EP & 42 & 6.99 & 0.012 \\
GS & 36 & 4.57 & 0.040
\end{tabular}



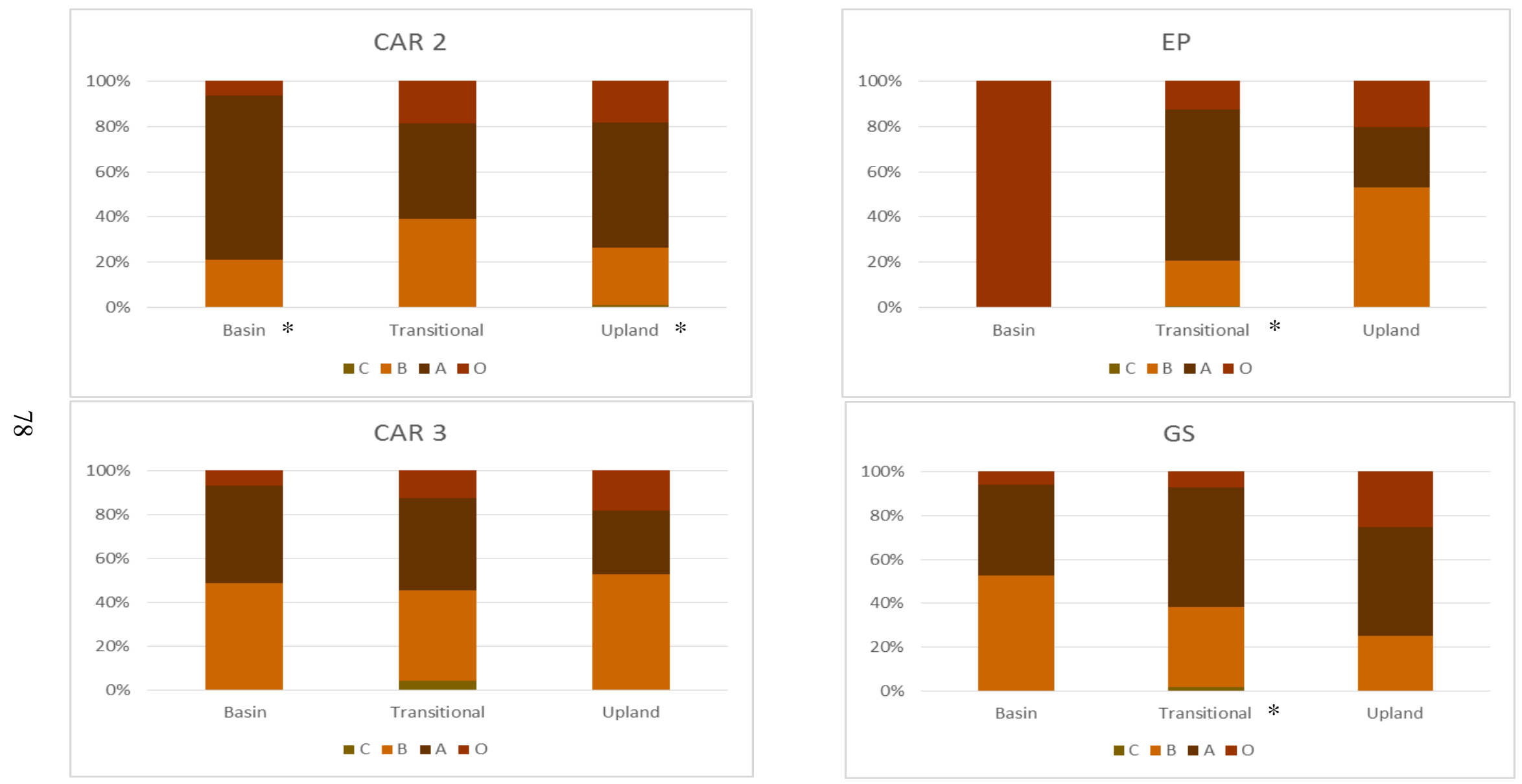

Figure 2.1. Proportion of the total SOC pool $\left(\mathrm{kg} \mathrm{C} \mathrm{m}^{-2}\right)$ stored in the master horizons of soils from each hydrologic zone. An asterisk $(*)$ is placed next to the zones that contained buried A horizons. 

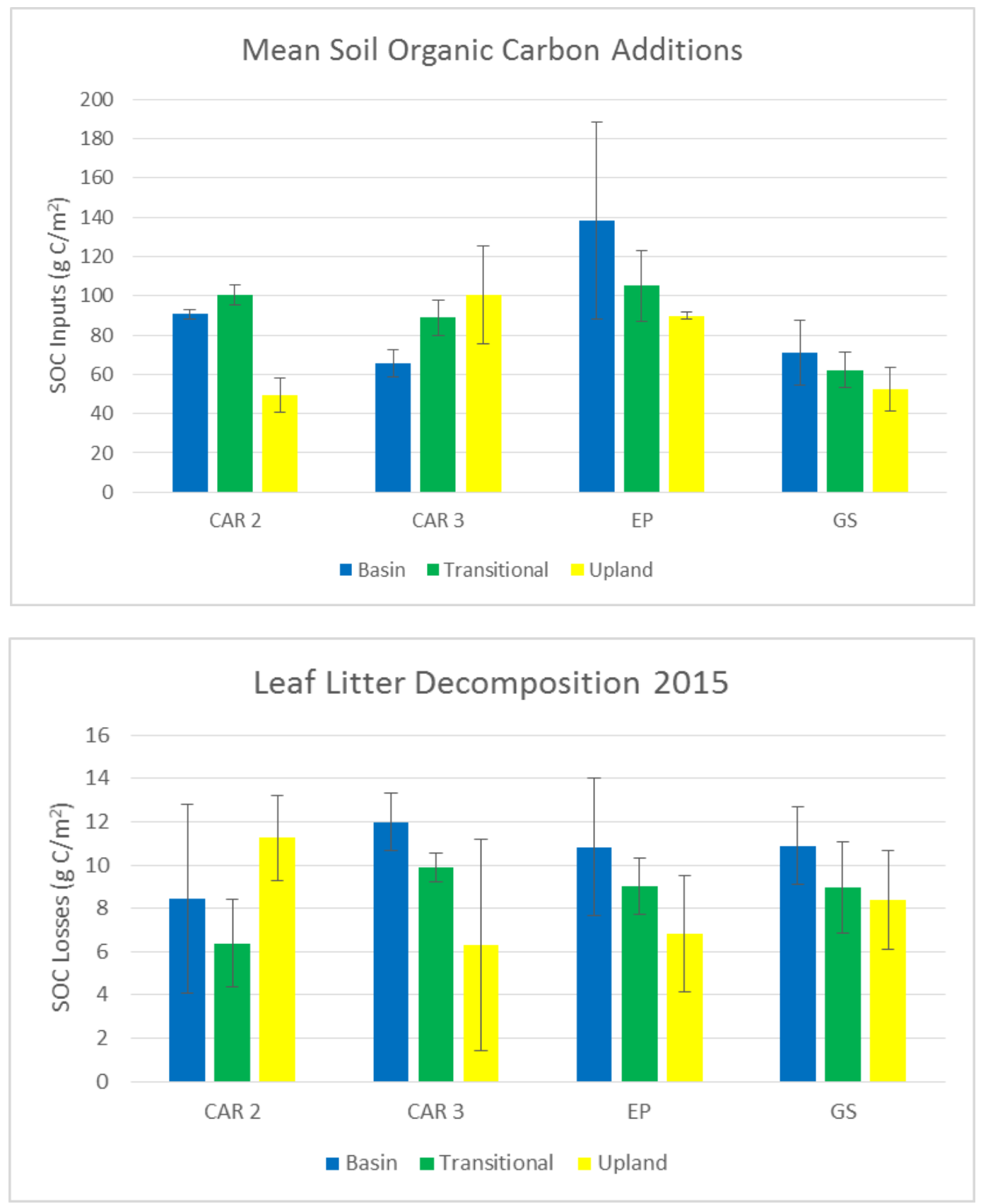

Figure 2.2. Mean SOC additions and mean SOC losses in the three hydrologic zones at each vernal pool. Each error bar represents +/- 1 standard deviation. 


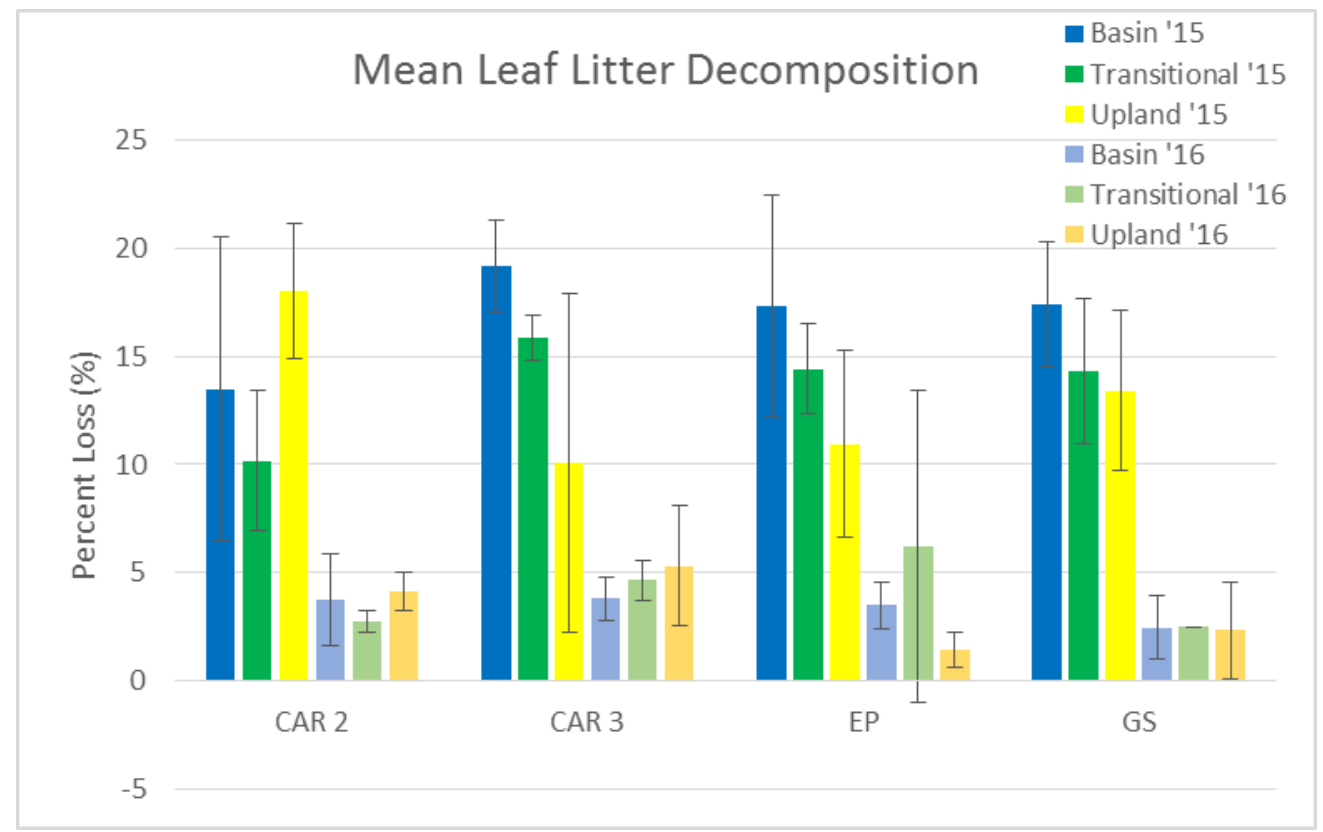

Figure 2.3. Mean leaf litter decomposition in the three hydrologic zones at each vernal pool during the 2015 and 2016 field seasons. Each error bar represents +/- 1 standard deviation.

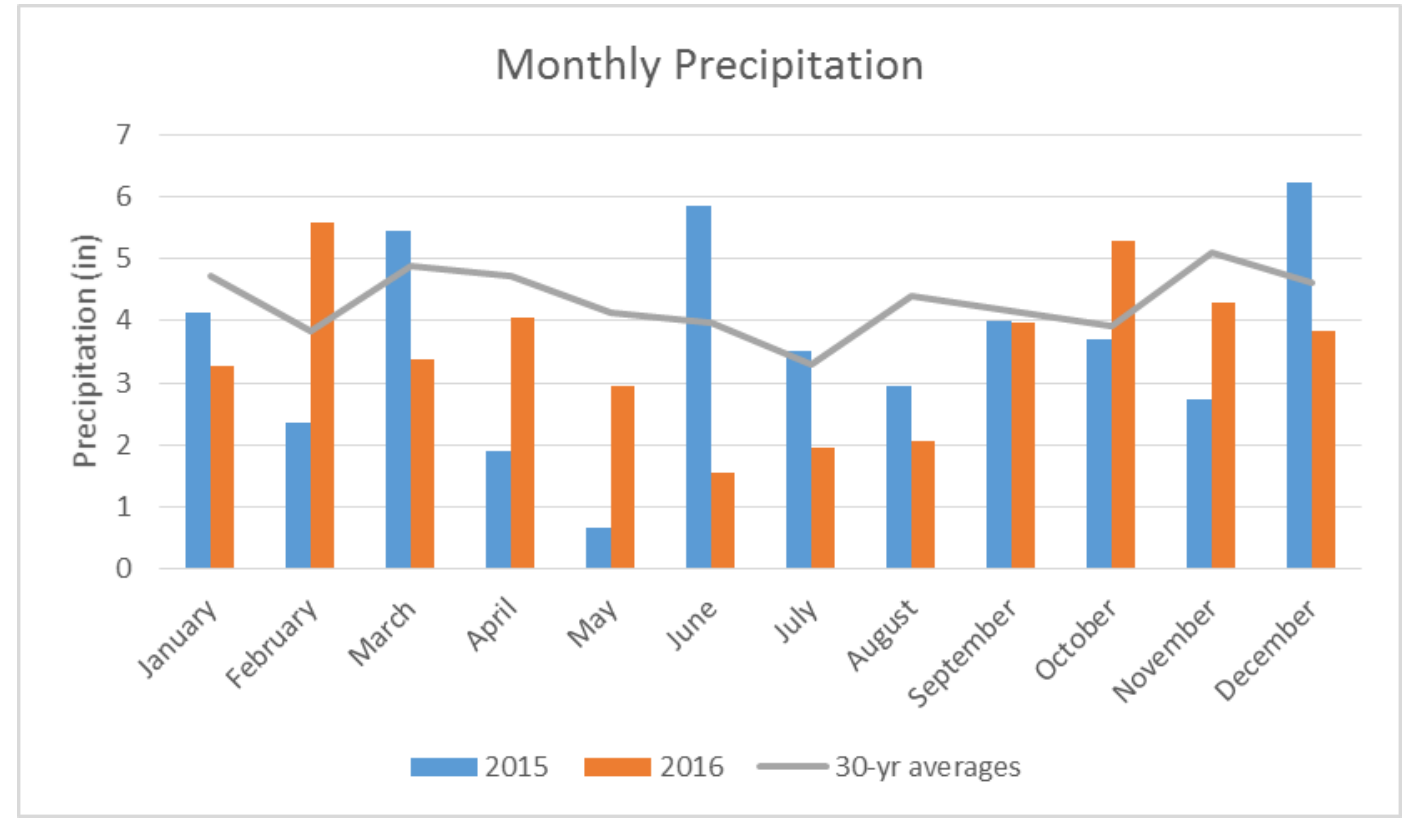

Figure 2.4. Total monthly precipitation during 2015 and 2016, compared to monthly 30-year averages (obtained from the Kingston WETS station: RI4266). 


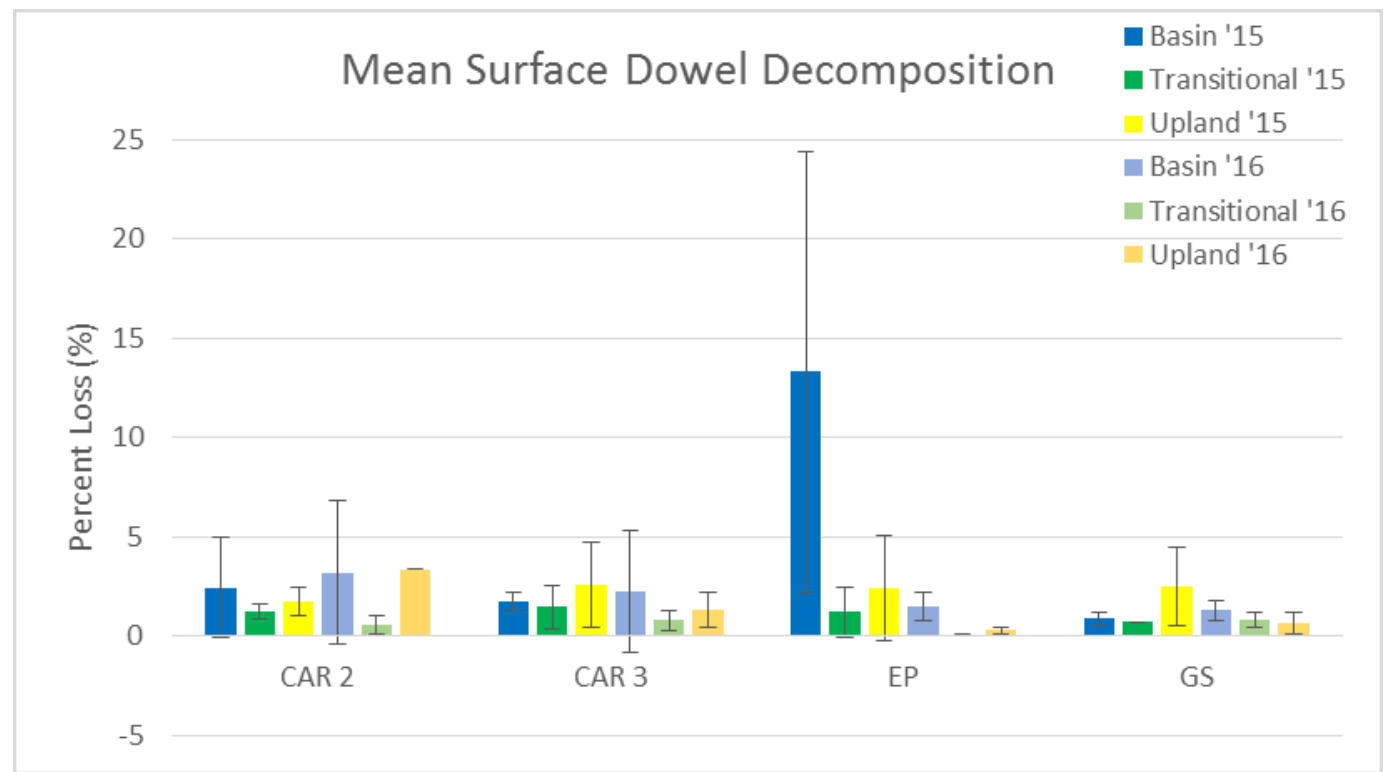

Figure 2.5. Mean surface dowel decomposition in the three hydrologic zones at each vernal pool during the 2015 and 2016 field seasons. Each error bar represents $+/-1$ standard deviation.

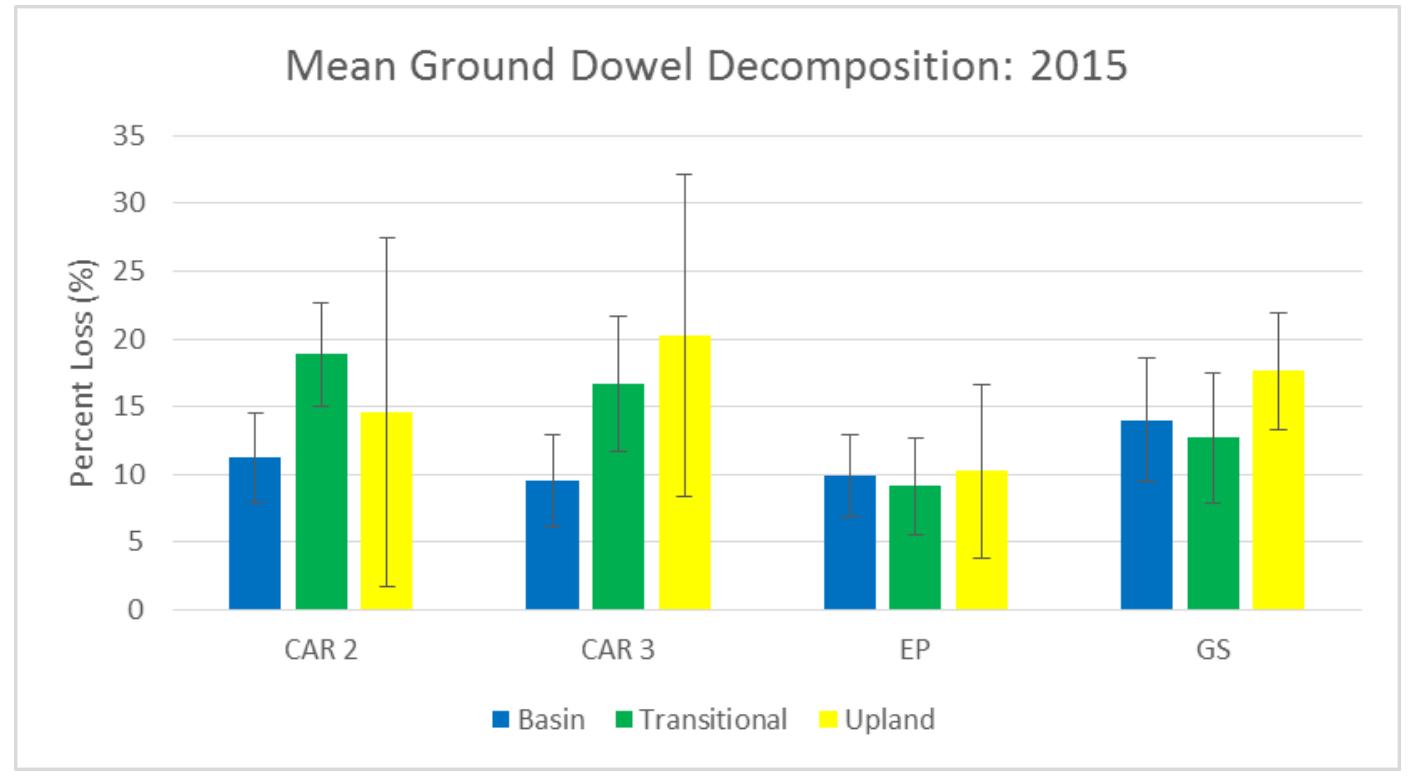

Figure 2.6. Mean ground dowel decomposition in the three hydrologic zones at each vernal pool during the 2015 and 2016 field seasons. Each error bar represents +/- 1 standard deviation. 

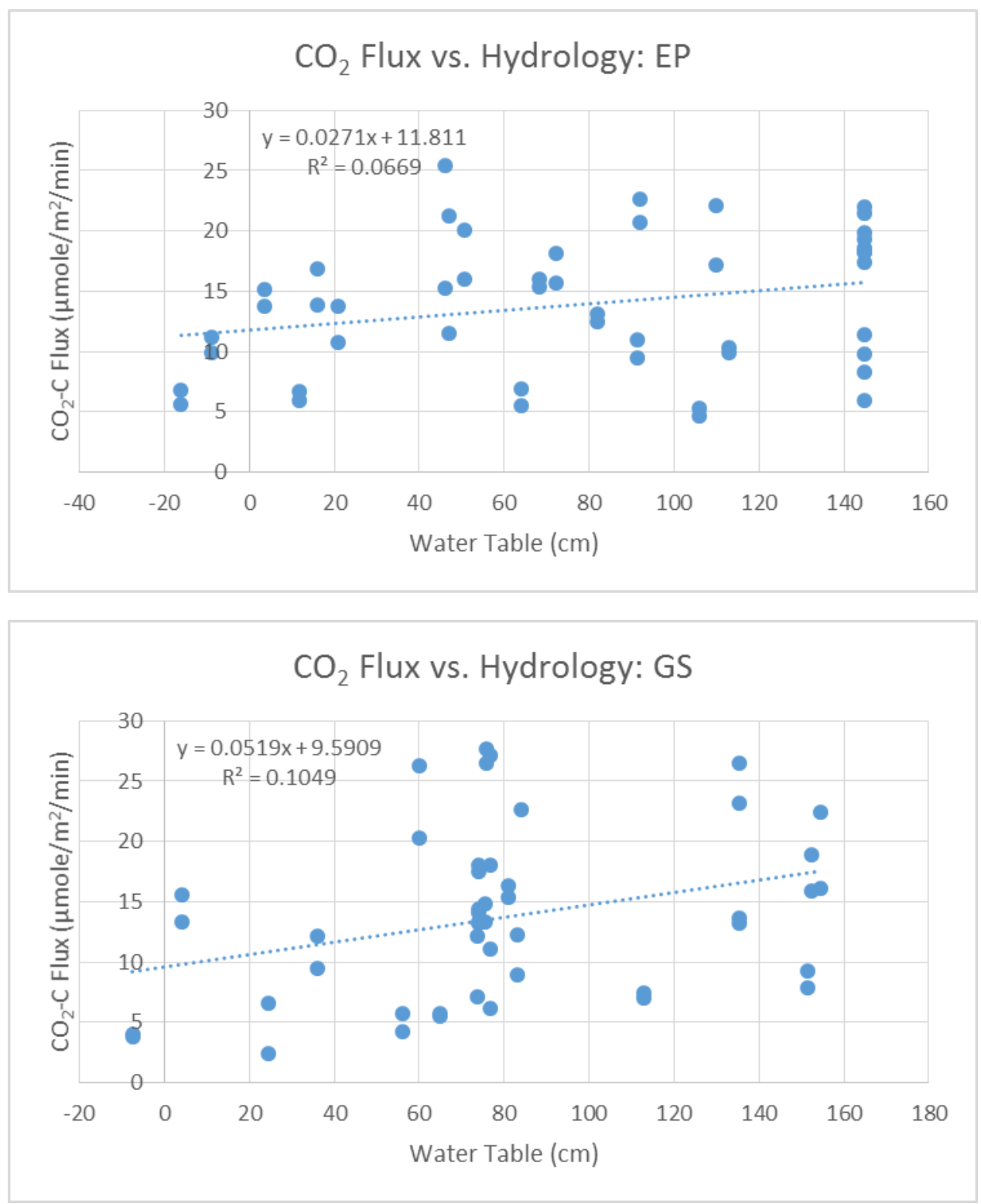

Figure 2.7. Regression analysis of $\mathrm{CO}_{2}$ flux compared to the water table level across all sampling months and hydrologic zones at Eppley $(\mathrm{p}=0.076)$ and Great Swamp $(\mathrm{p}=0.026)$. Water table depth refers to the distance between the soil surface and the water table. 


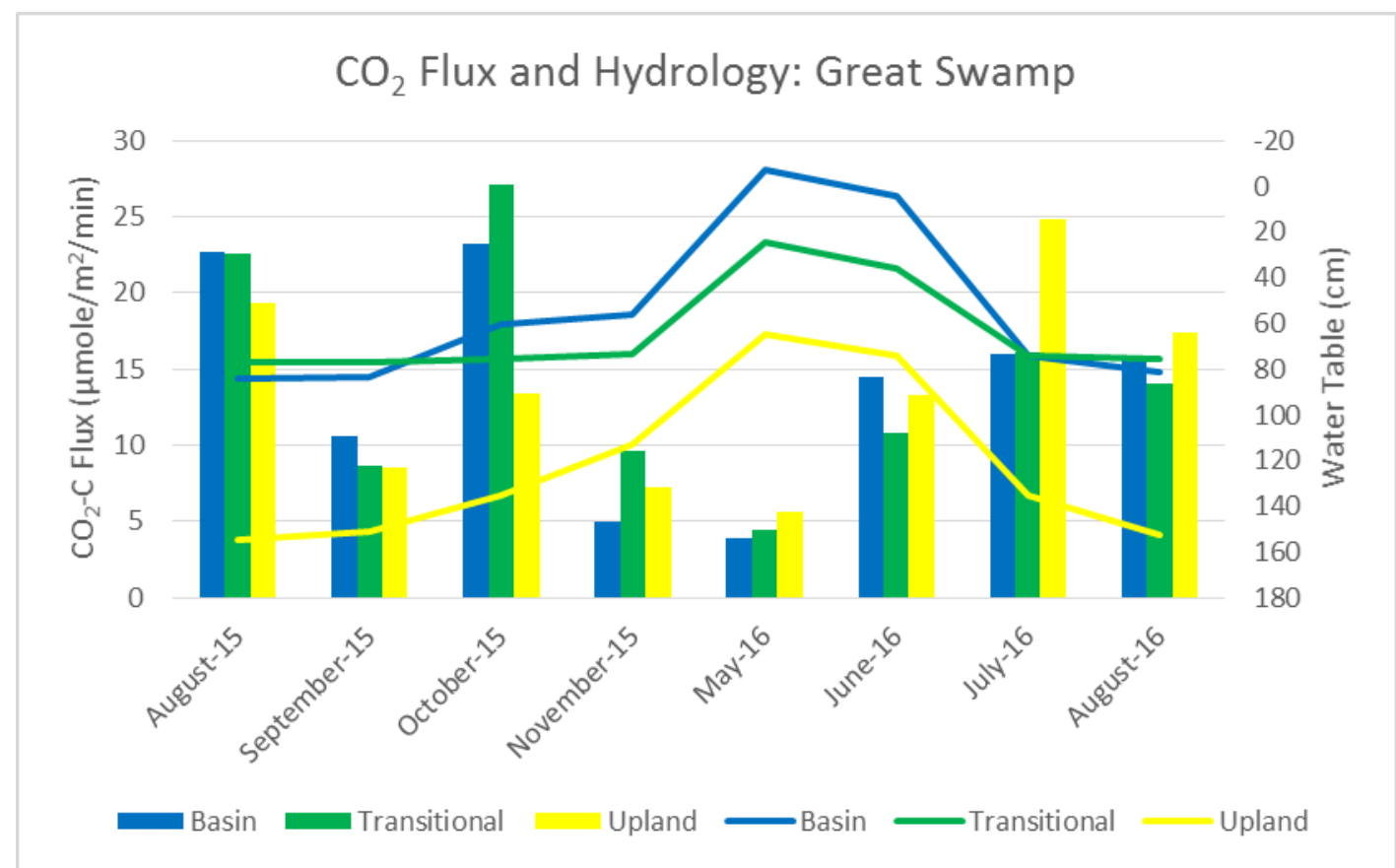

Figure 2.8. Monthly $\mathrm{CO}_{2}$ flux compared to soil hydrology. Water table levels were obtained from Odyssey loggers.

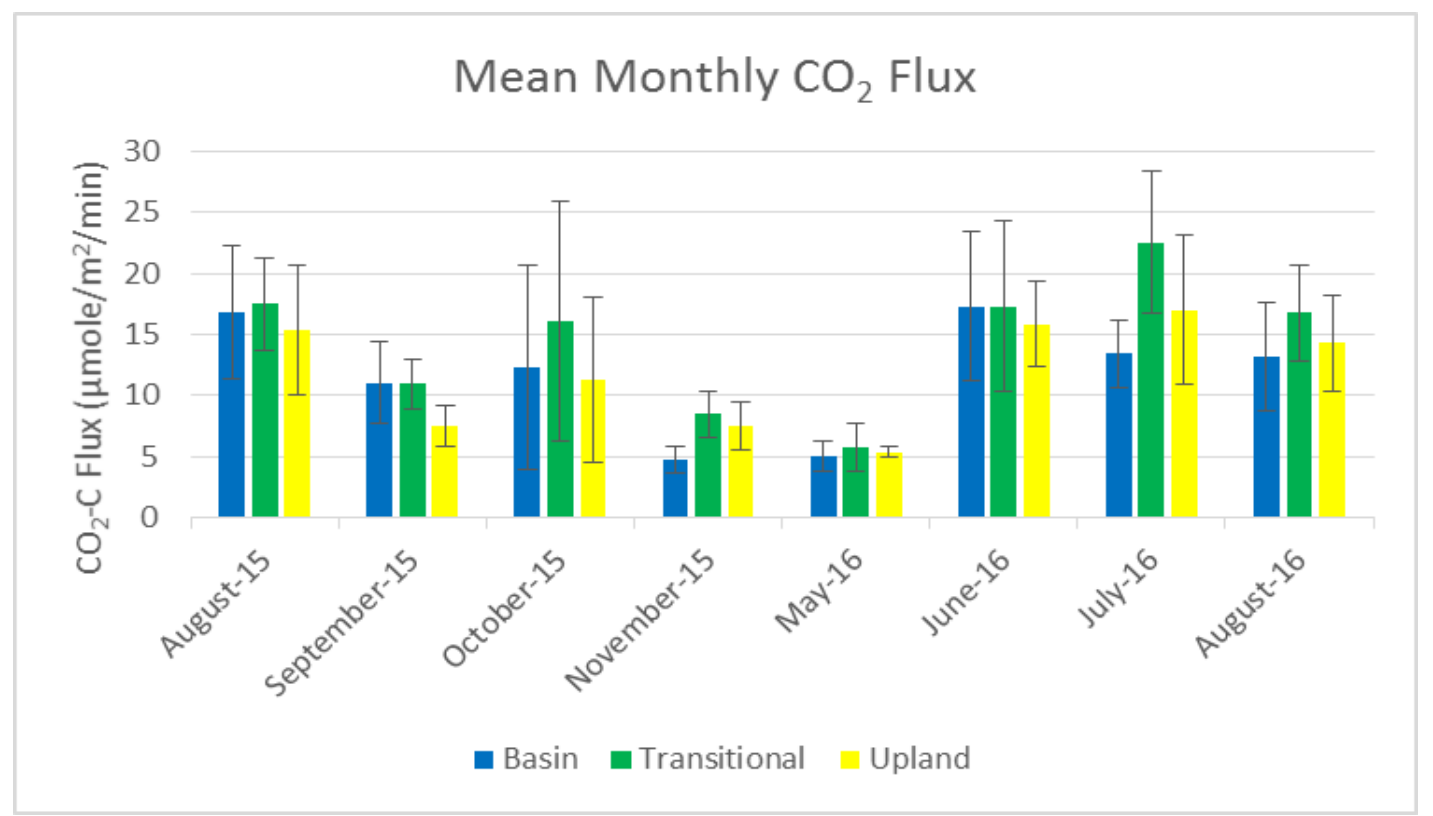

Figure 2.9. Mean monthly $\mathrm{CO}_{2}$ fluxes across all vernal pools. Each error bar represents $+/-1$ standard deviation. 


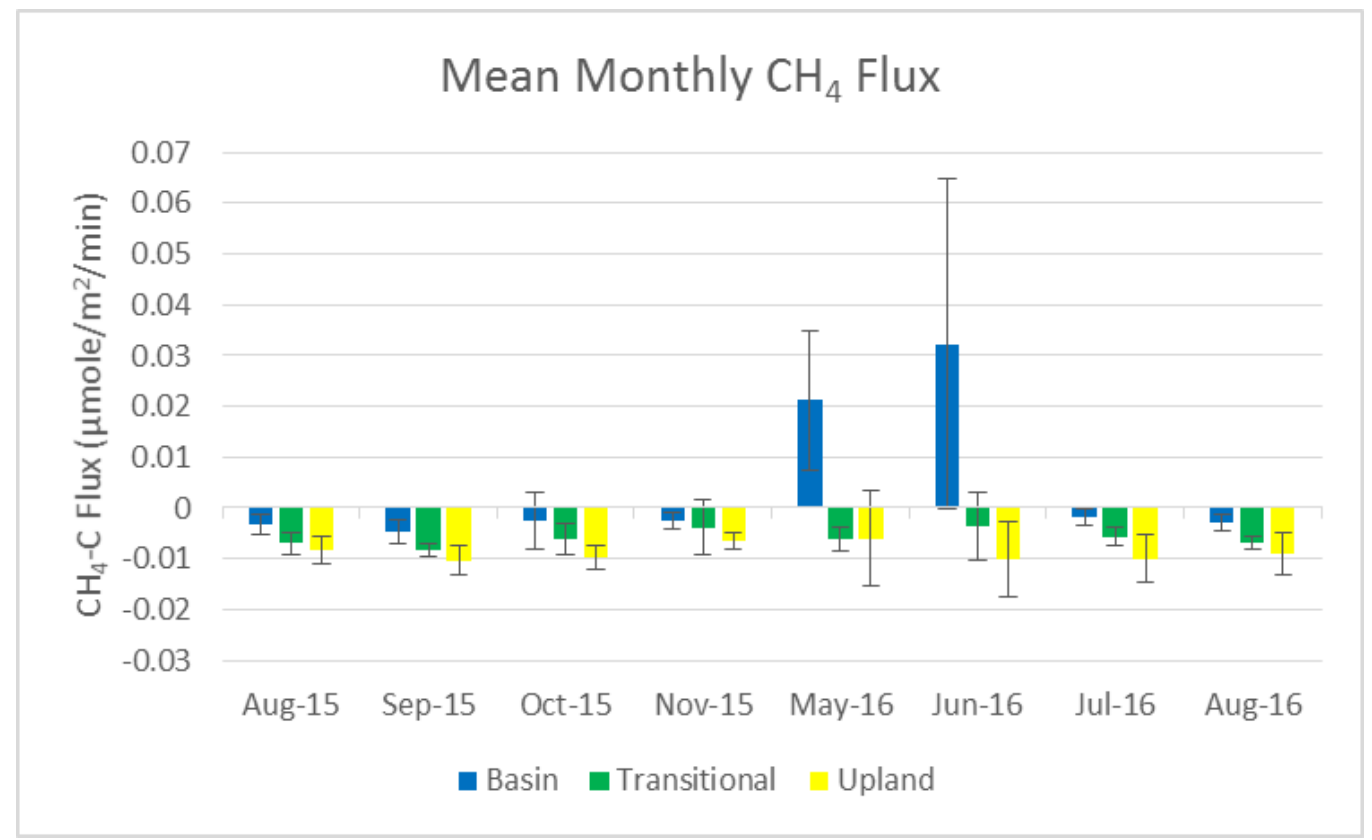

Figure 2.10. Mean monthly $\mathrm{CH}_{4}$ fluxes across all vernal pools. A positive flux value indicates that the pools emitted $\mathrm{CH}_{4}$ to the atmosphere, while a negative flux indicates a net absorption of $\mathrm{CH}_{4}$. Each error bar represents +/- 1 standard deviation.

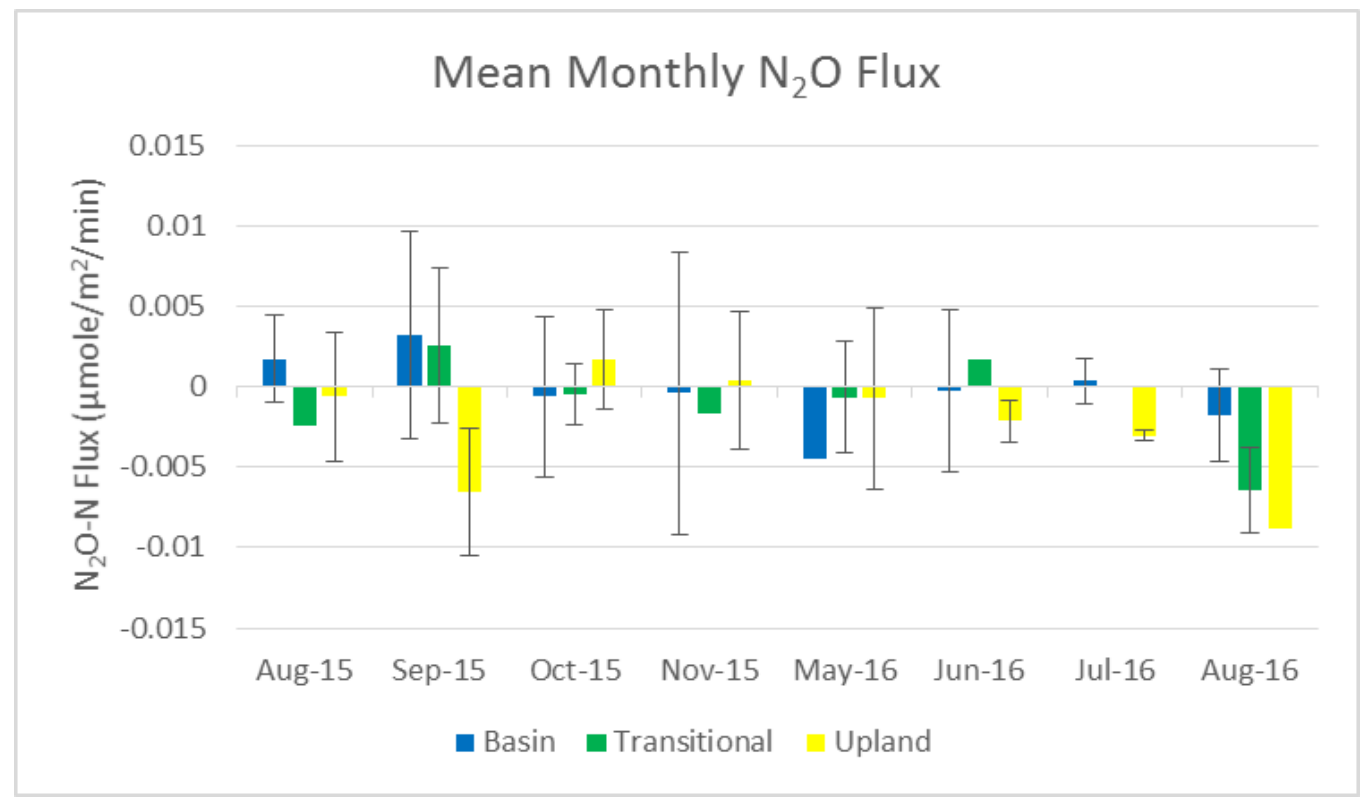

Figure 2.11. Mean monthly $\mathrm{N}_{2} \mathrm{O}$ fluxes across all vernal pools. A positive flux value indicates that the pools emitted $\mathrm{N}_{2} \mathrm{O}$ to the atmosphere, while a negative flux indicates a net absorption of $\mathrm{N}_{2} \mathrm{O}$. Each error bar represents $+/-1$ standard deviation 


\section{APPENDICES}

APPENDIX 1. Experimental design of vernal pools.

T1 represents the main transect, and red boxes represent well locations and numbers. Only one well was placed in the basin; the two colorless boxes in the basin were used as plots when evaluating the decomposition of ground dowels.

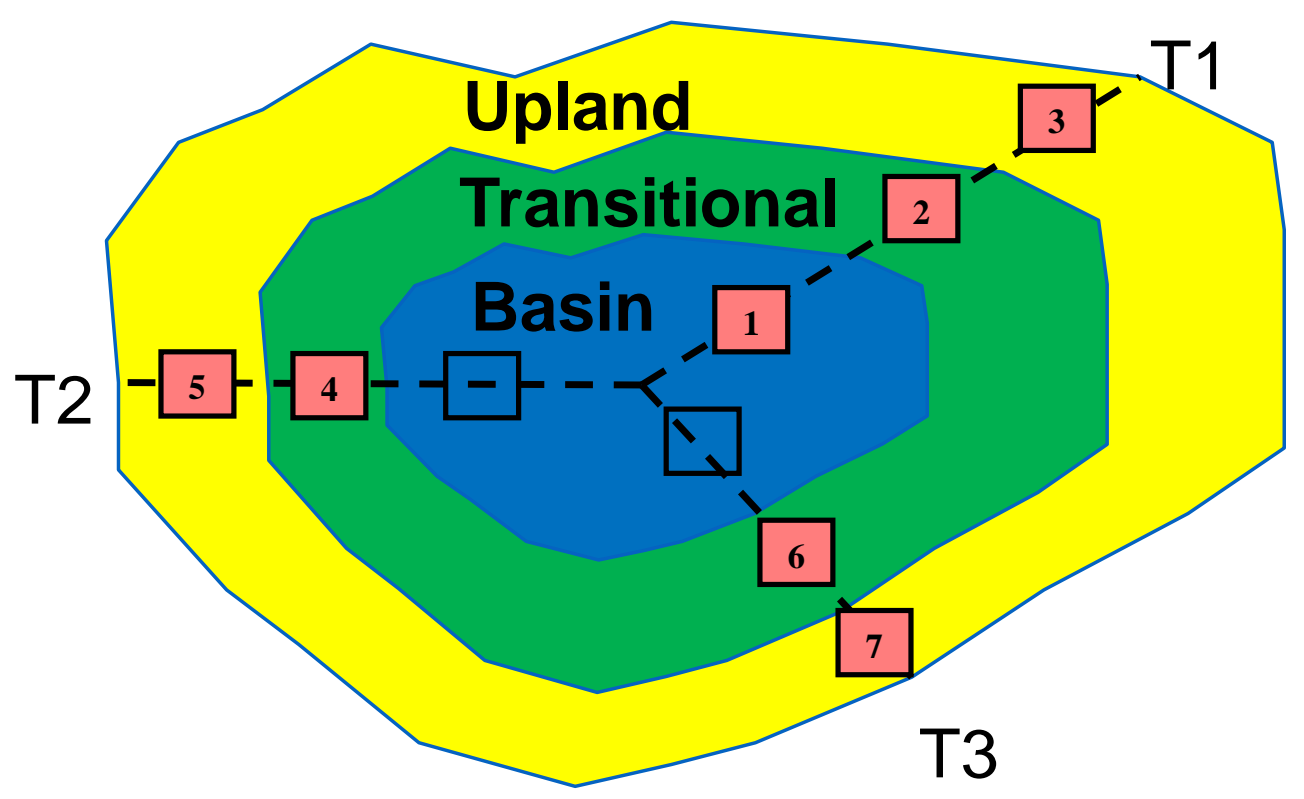


APPENDIX 2. Odyssey logger measurements for each vernal pool over the course of this study.

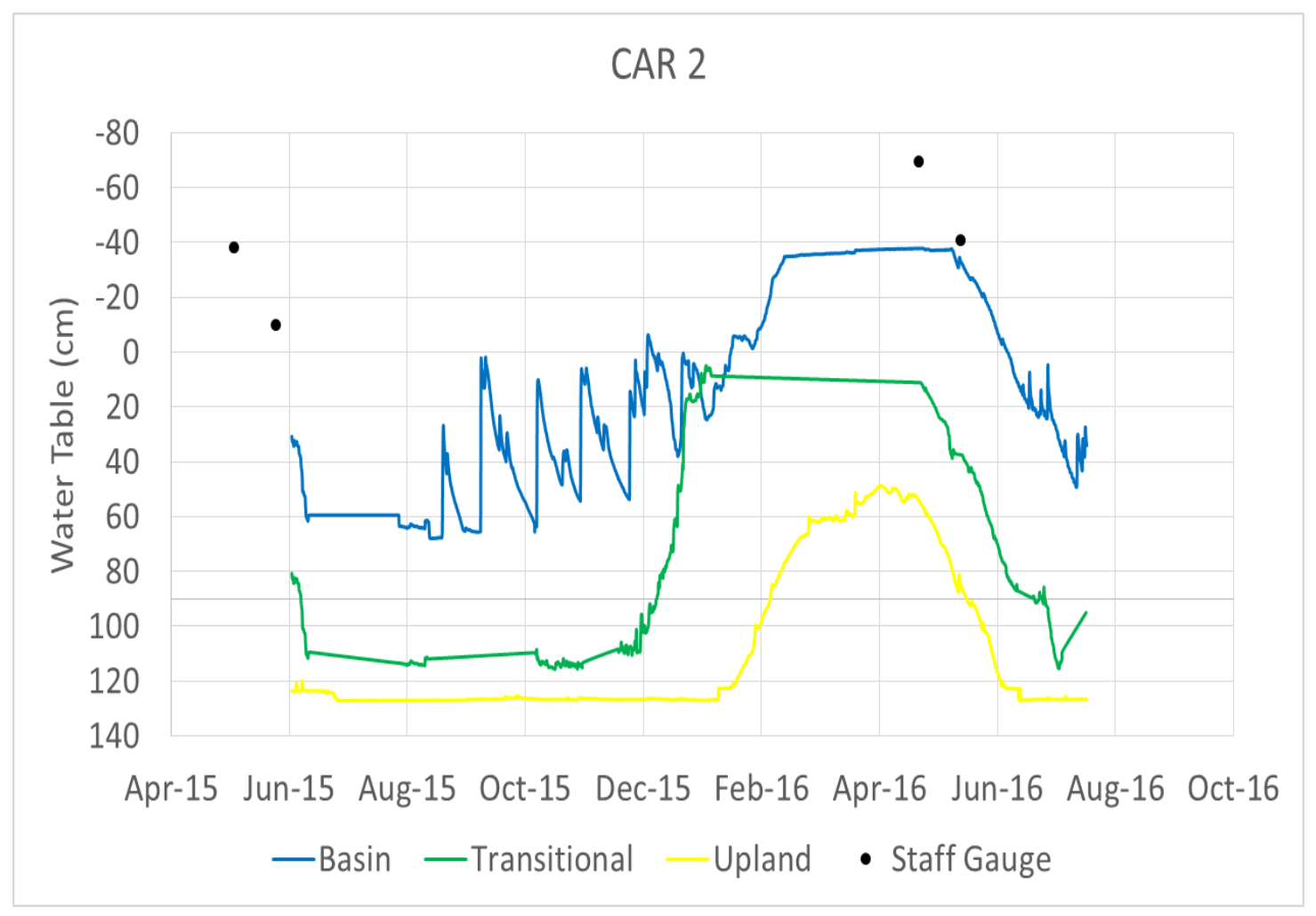




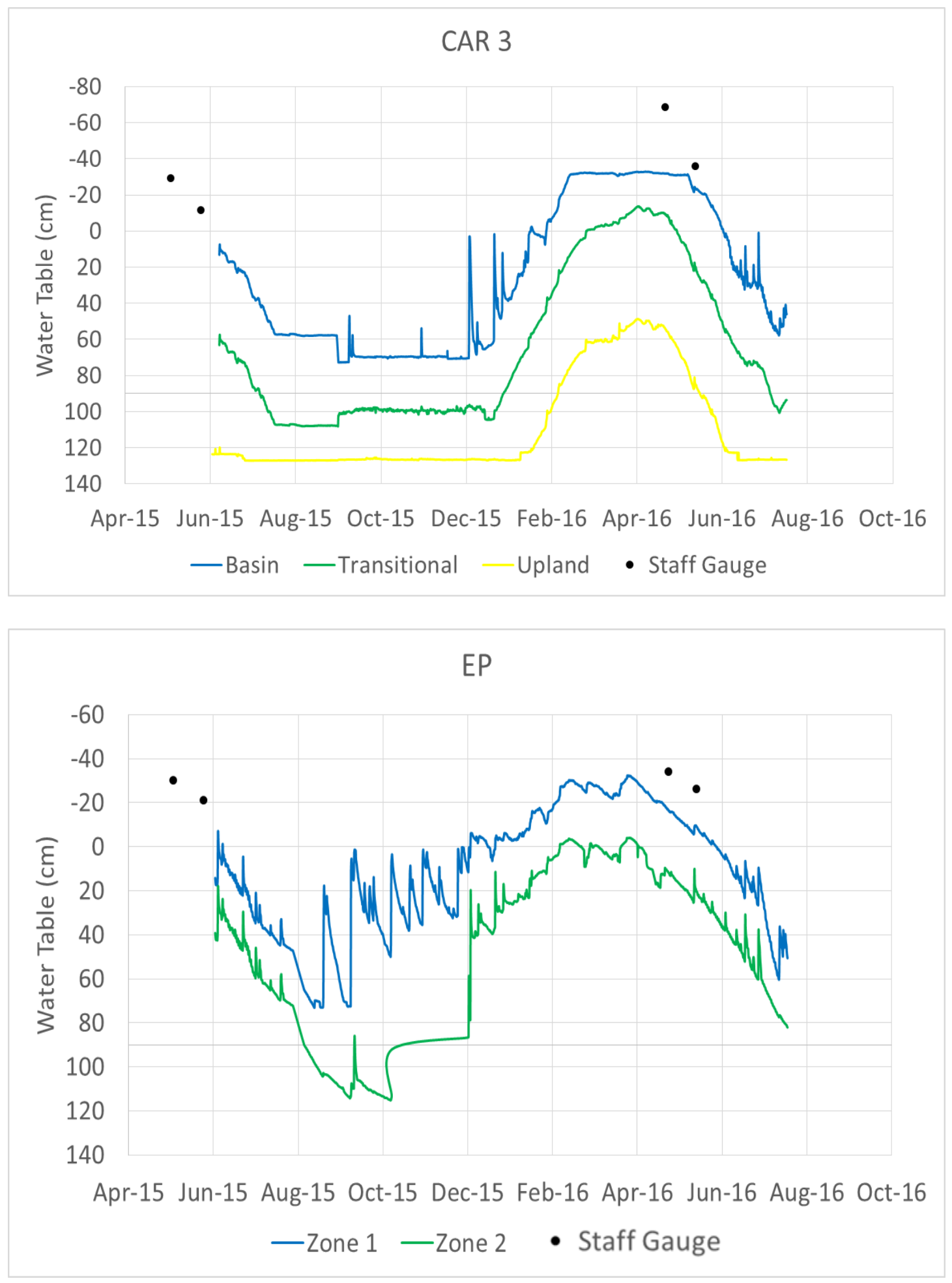


APPENDIX 3. Average monthly temperatures during 2015 and 2016 as compared to 30 -year averages.

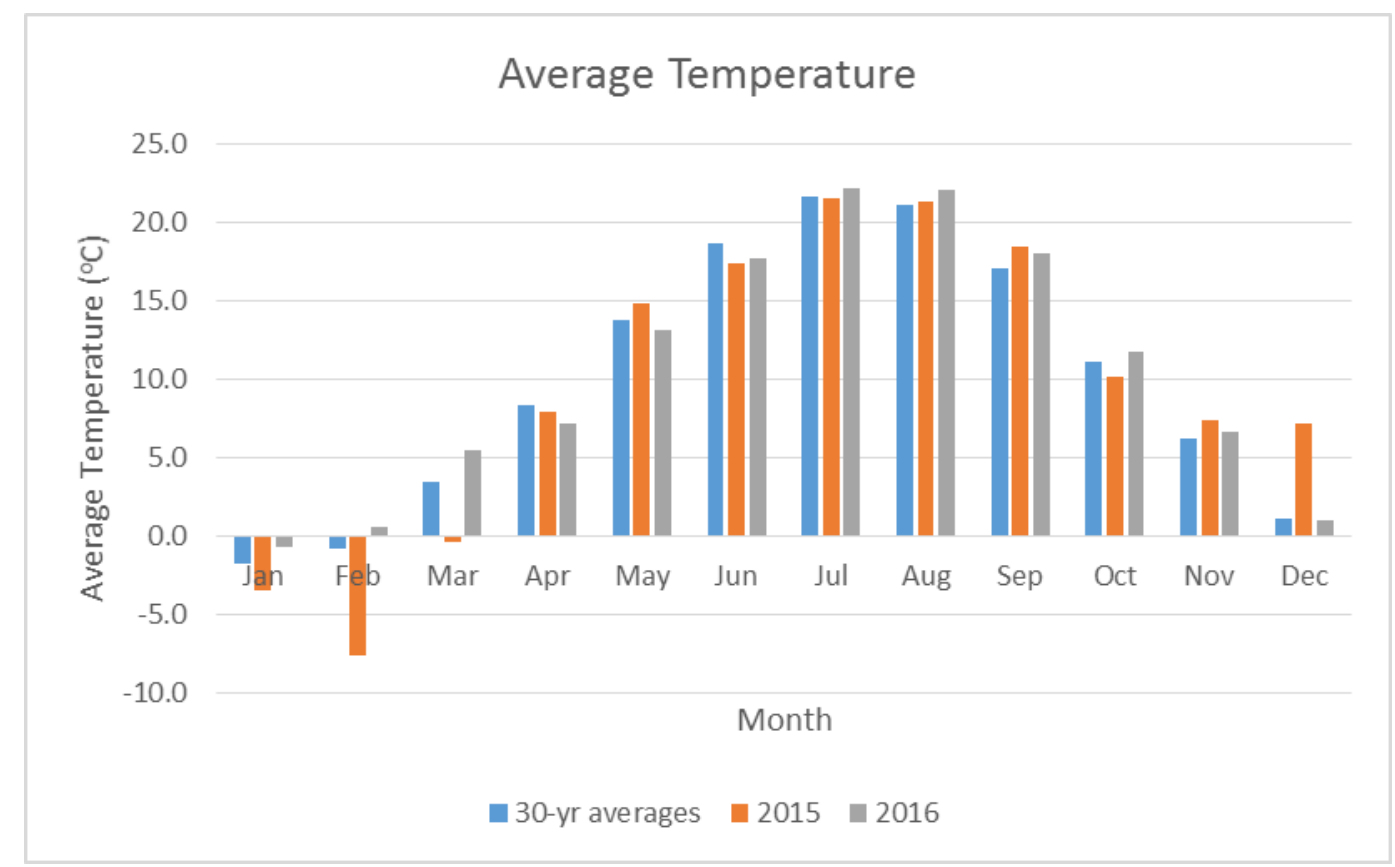


APPENDIX 4. Hydraulic gradients of main and supplementary transects at each vernal pool.
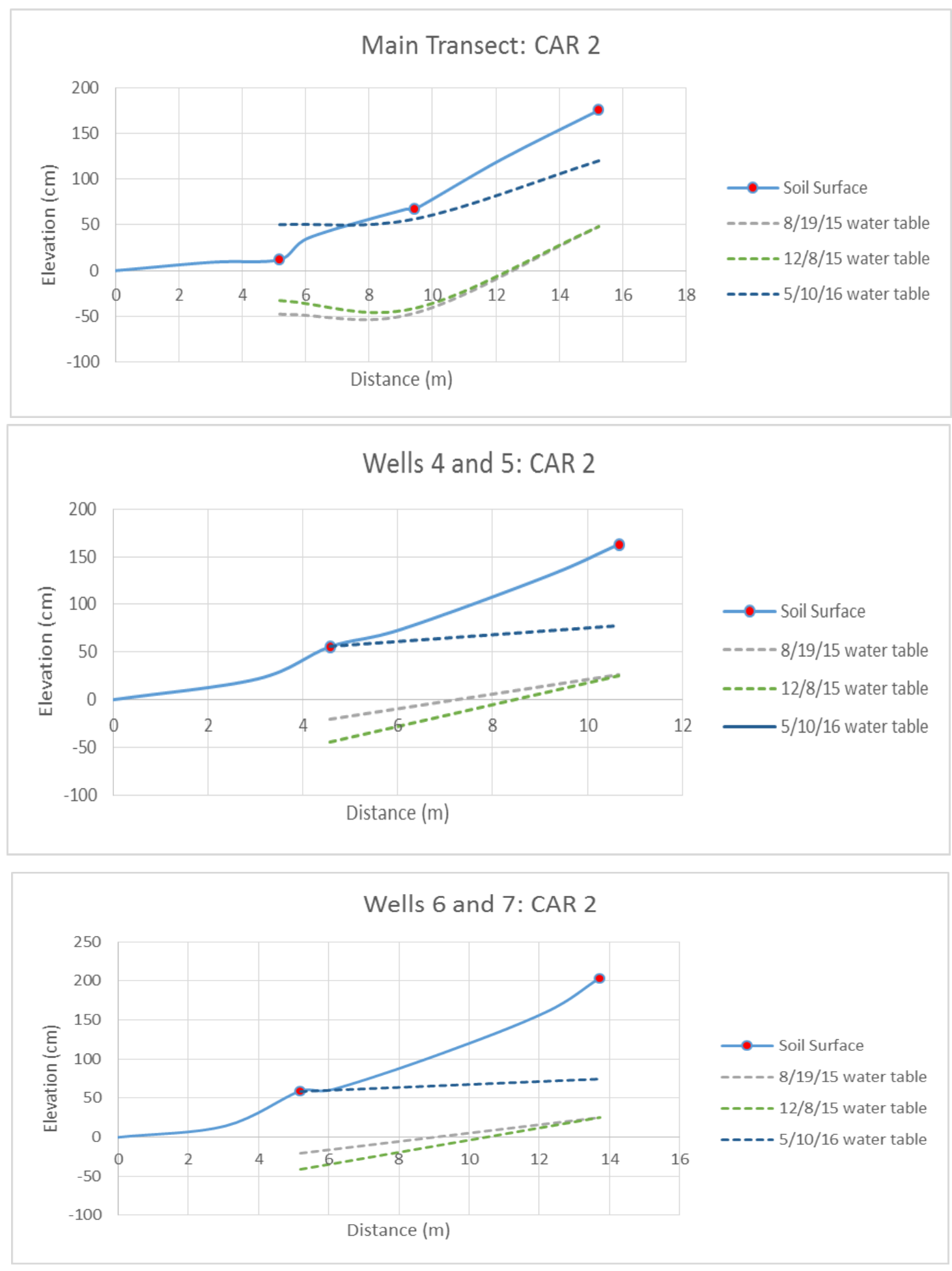

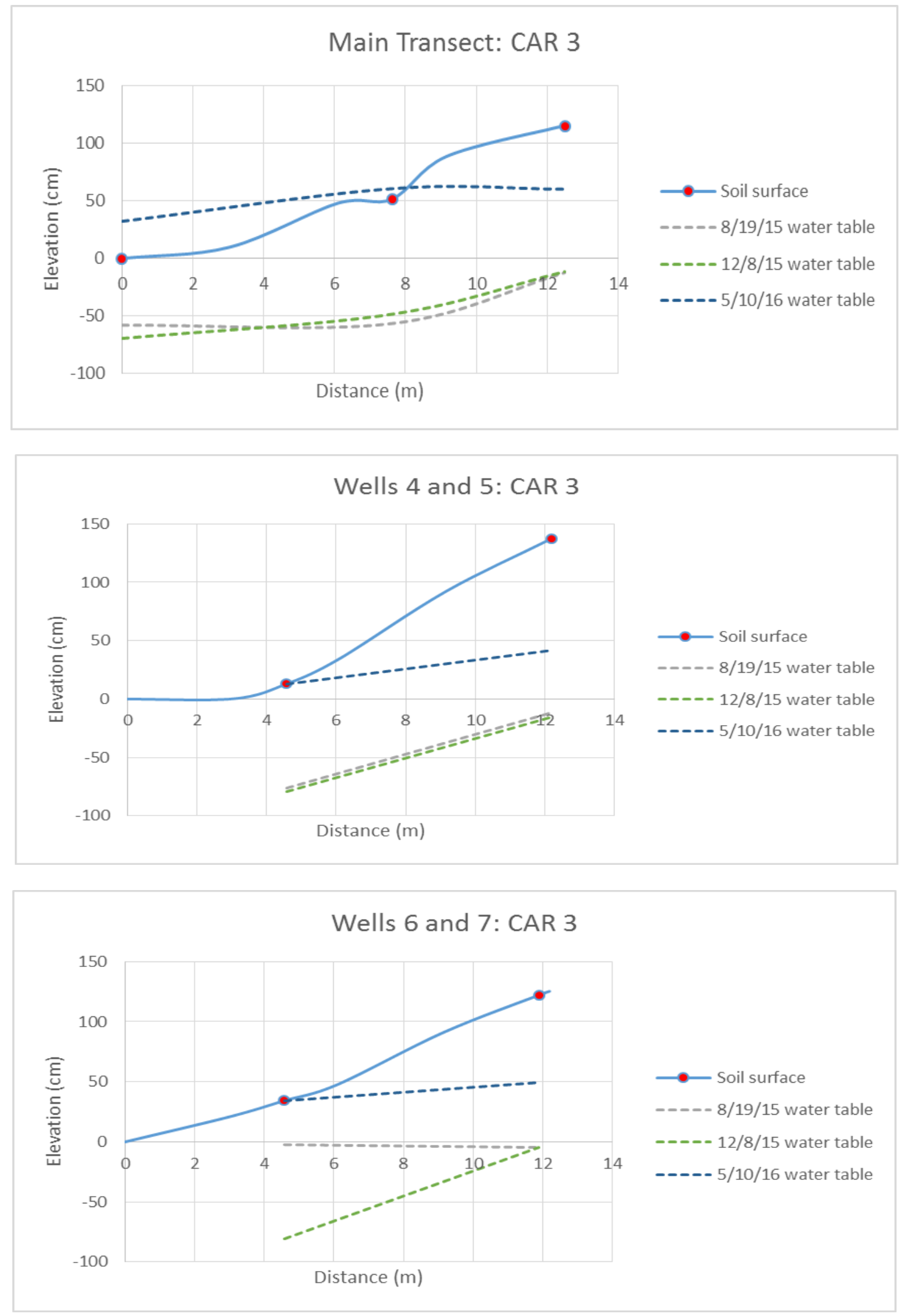

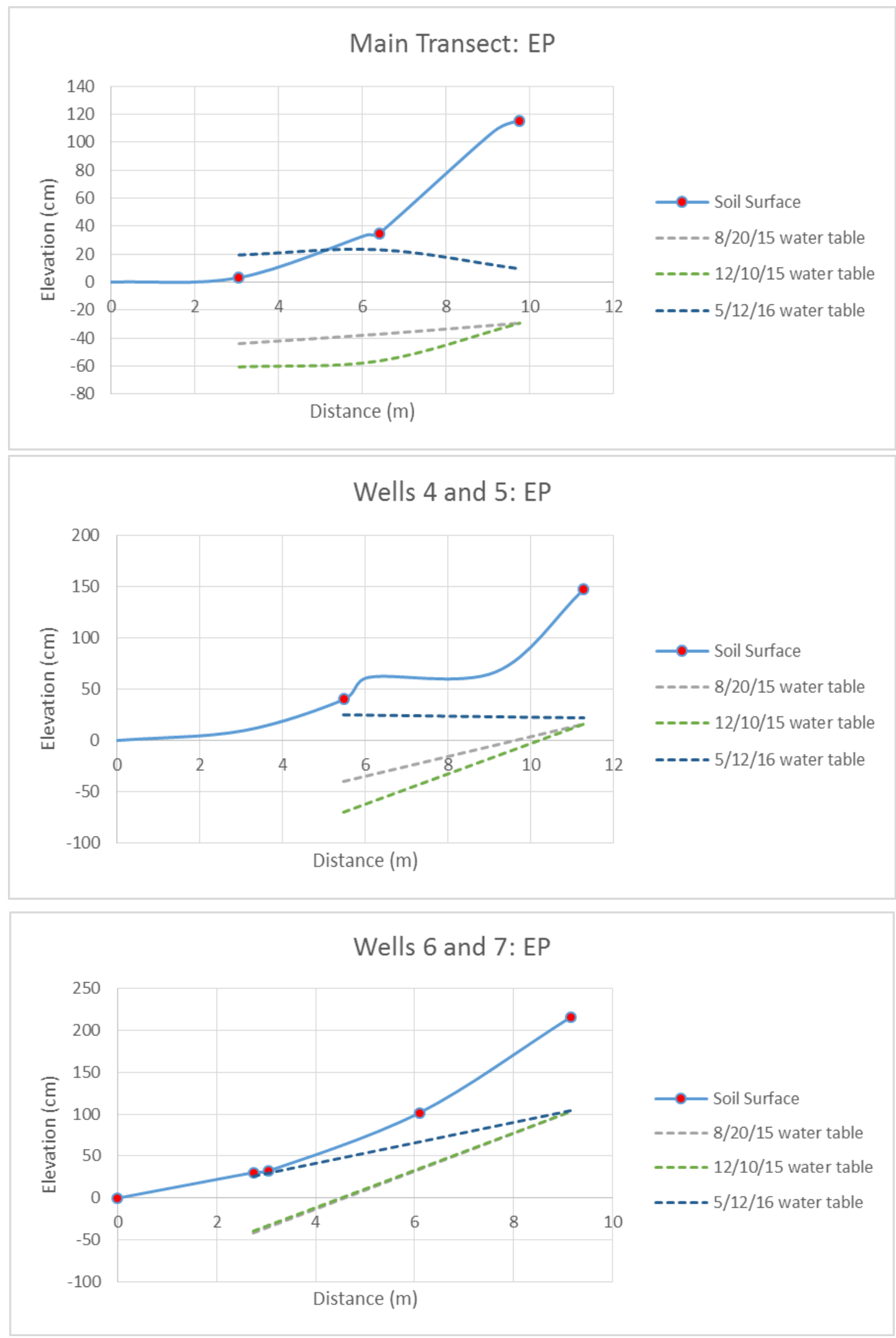

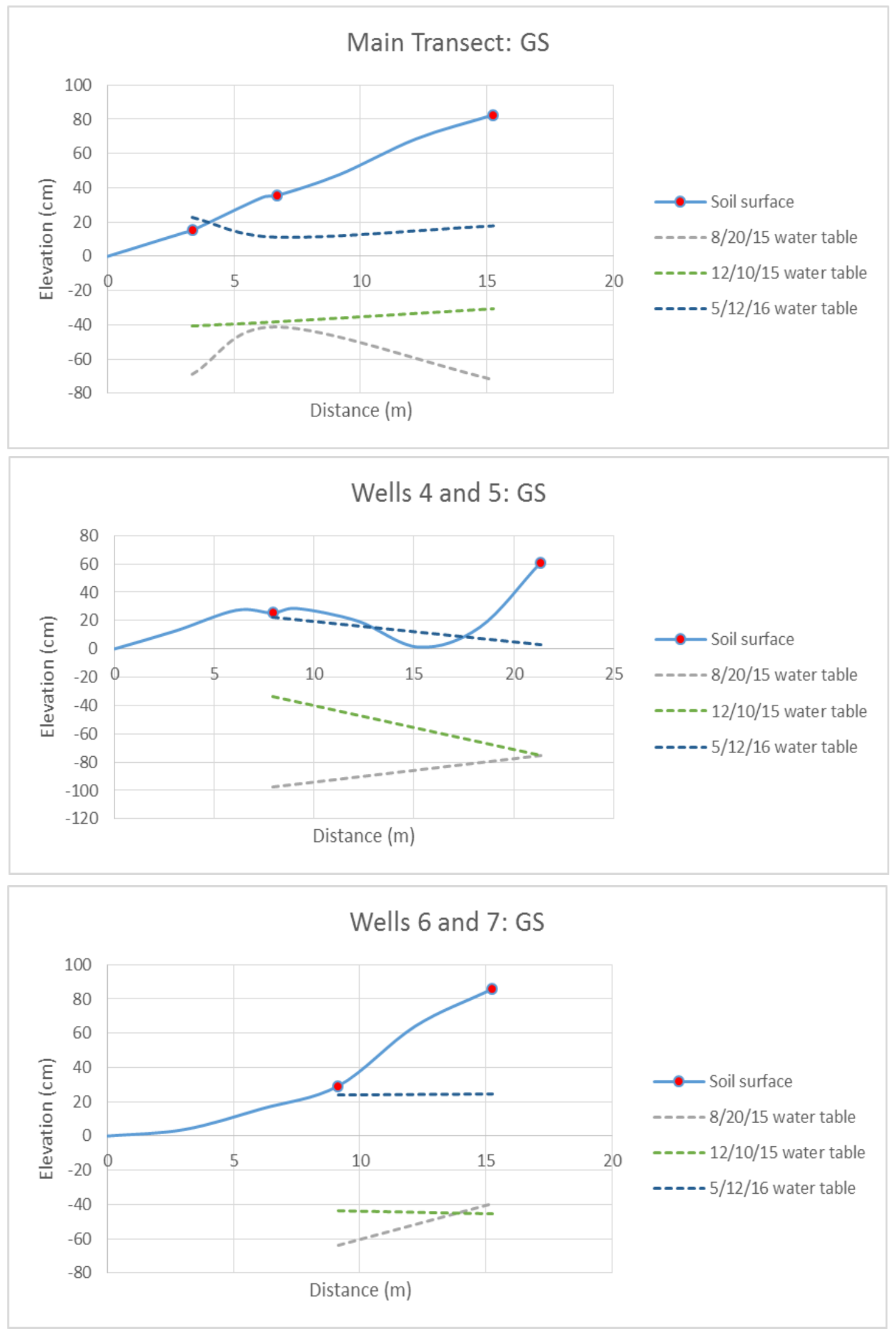
APPENDIX 5. Morphological descriptions of the soils at each vernal pool.

CAR 2; Transitional Zone

\begin{tabular}{c|ccccc}
\hline Horizon & $\begin{array}{c}\text { Lower } \\
\text { Depth } \\
(\mathrm{cm})\end{array}$ & $\begin{array}{c}\text { Texture } \\
\text { Class }\end{array}$ & Color & Depletions & Concentrations \\
\hline Oi & 7 & Fibric & 10YR 2/2 & - & - \\
AE & 38 & SL & 10 YR 2/1 & - & - \\
Bhs1 & 62 & COSL & 7.5 YR 3/1 & - & - \\
Bhs2 & 98 & SL & $7.5 Y R 2.5 / 2$ & - & Few, Fnt. \\
Bhs3 & 122 & GR SL & $7.5 Y R 3 / 3$ & Few, Fnt. & Com., Fnt. \\
Bhs4 & $150+$ & GR SL & 10 YR 3/3 & Few, Fnt. & Few, Fnt.
\end{tabular}

CAR 2; Upland Zone

\begin{tabular}{c|ccccc}
\hline Horizon & $\begin{array}{c}\text { Lower } \\
\text { Depth } \\
(\mathrm{cm})\end{array}$ & $\begin{array}{c}\text { Texture } \\
\text { Class }\end{array}$ & Color & Depletions & Concentrations \\
\hline Oe & 2 & Hemic & 10YR 2/2 & - & - \\
$\mathrm{AE}$ & 10 & SL & 10YR 4/2 & - & - \\
$\mathrm{AB}$ & 23 & SL & 10YR 3/2 & - & - \\
Bw1 & 40 & COSL & 10YR 4/6 & - & - \\
Bw2 & 75 & GR COSL & 10YR 5/4 & - & - \\
Bw3 & 115 & GR COSL & 10YR 5/6 & - & - \\
C & $150+$ & GR COSL & 10YR 6/3 & - & - \\
& & & & &
\end{tabular}

CAR 3; Basin Zone

\begin{tabular}{c|ccccc}
\hline Horizon & $\begin{array}{c}\text { Lower } \\
\text { Depth } \\
(\mathrm{cm})\end{array}$ & $\begin{array}{c}\text { Texture } \\
\text { Class }\end{array}$ & Color & Depletions & Concentrations \\
\hline Oe & 7 & Hemic & 10YR 3/1 & - & - \\
A & 24 & SIL & 10YR 2/1 & - & - \\
AB & 40 & COSL & 10YR 3/1 & - & - \\
Bhs1 & 62 & COSL & 10YR 3/2 & - & - \\
Bhs2 & 89 & SL & $7.5 Y R 2.5 / 2$ & - & Com., dist. \\
Bhs3 & 130 & COSL & $7.5 Y R 3 / 3$ & Few, dist. & Com., dist. \\
Bhs4 & $150+$ & SL & $7.5 Y R 3 / 2$ & Few, fnt. & Com., dist.
\end{tabular}


CAR 3; Upland Zone

\begin{tabular}{c|ccccc}
\hline Horizon & $\begin{array}{c}\text { Lower } \\
\text { Depth } \\
(\mathrm{cm})\end{array}$ & $\begin{array}{c}\text { Texture } \\
\text { Class }\end{array}$ & Color & Depletions & Concentrations \\
\hline Oe & 3 & Hemic & 10 YR 2/2 & - & - \\
AE & 25 & SL & 10 YR 2/1 & - & - \\
Bw1 & 36 & SL & $7.5 Y R 3 / 2$ & - & - \\
Bw2 & 50 & SL & $10 Y R 3 / 3$ & - & - \\
Bw3 & 78 & GR SL & 10 YR 4/3 & - & - \\
BC & 125 & GR COSL & 10 YR 5/3 & - & - \\
C & $150+$ & VGR LCOS & $10 Y R 5 / 3$ & - & -
\end{tabular}

EP; Basin Zone

\begin{tabular}{c|ccccc}
\hline Horizon & $\begin{array}{c}\text { Lower } \\
\text { Depth } \\
(\mathrm{cm})\end{array}$ & $\begin{array}{c}\text { Texture } \\
\text { Class }\end{array}$ & Color & Depletions & Concentrations \\
\hline Oe & 3 & Hemic & 10YR 2/2 & - & - \\
Oa1 & 25 & Sapric & 10YR 2/1 & - & - \\
Oa2 & 65 & Sapric & 10YR 3/1 & - & - \\
Oa3 & 95 & Sapric & 10YR 2/1 & - & - \\
Oa4 & $120+$ & Sapric & 10YR 2/1 & - & -
\end{tabular}

EP; Transitional Zone

\begin{tabular}{c|ccccc}
\hline Horizon & $\begin{array}{c}\text { Lower } \\
\text { Depth } \\
(\mathrm{cm})\end{array}$ & $\begin{array}{c}\text { Texture } \\
\text { Class }\end{array}$ & Color & Depletions & Concentrations \\
\hline Oi & 9 & Fibric & 10YR 2/2 & - & - \\
$\mathrm{AE}$ & 32 & SL & 5 Y $2.51 / 1$ & Few, Dist. & Few, Dist. \\
Bg1 & 53 & SL & $5 Y 3 / 1$ & Com., Fnt. & Com., Dist. \\
Bg2 & 77 & COSL & $2.5 Y 4 / 1$ & Com., Fnt. & Com., Dist. \\
Bg3 & 91 & SL & $2.5 Y 3 / 1$ & Com., Dist. & Com., Dist. \\
BCg & 110 & COSL & $2.5 Y 5 / 1$ & Com., Fnt. & Com., Dist. \\
Cg & 134 & LCS & $5 Y$ Y 6/1 & Com., Fnt. & Few, Dist.
\end{tabular}

GS; Basin Zone

\begin{tabular}{|c|c|c|c|c|c|}
\hline Horizon & $\begin{array}{l}\text { Lower } \\
\text { Depth } \\
(\mathrm{cm})\end{array}$ & $\begin{array}{c}\text { Texture } \\
\text { Class }\end{array}$ & Color & Depletions & Concentrations \\
\hline Oe & 3 & Hemic & 10YR $2 / 2$ & - & - \\
\hline A & 17 & SIL & 10YR 2/1 & - & - \\
\hline $\mathrm{Ag}$ & 33 & SL & $5 Y 3 / 1$ & Few, Dist. & Few, Dist. \\
\hline Bhs & 63 & SL & 7.5 YR $3 / 2$ & Com., Fnt. & Com., Dist. \\
\hline $\mathrm{Bw}$ & 93 & SL & $2.5 \mathrm{Y} 4 / 3$ & Com., Fnt. & Com., Dist. \\
\hline Bg1 & 120 & COSL & $2.5 Y$ 5/2 & Com., Dist. & Many, Dist. \\
\hline Bg2 & $150+$ & COSL & $2.5 Y 5 / 2$ & Com., Dist. & Many, Dist. \\
\hline
\end{tabular}


GS; Transitional Zone

\begin{tabular}{|c|c|c|c|c|c|}
\hline Horizon & $\begin{array}{l}\text { Lower } \\
\text { Depth } \\
\text { (cm) }\end{array}$ & $\begin{array}{c}\text { Texture } \\
\text { Class }\end{array}$ & Color & Depletions & Concentrations \\
\hline $\mathrm{Oe}$ & 7 & Hemic & 10YR 2/2 & - & - \\
\hline $\mathrm{AE}$ & 17 & FSL & 10YR 2/1 & - & - \\
\hline Bhs & 36 & FSL & 7.5YR 3/2 & - & - \\
\hline Bw1 & 69 & SL & $10 Y R$ 4/3 & Com., Fnt. & Com., Dist. \\
\hline Bw2 & 90 & SL & $2.5 \mathrm{Y} 5 / 3$ & Com., Dist. & Many, Prom. \\
\hline $\mathrm{Bg}$ & 110 & SL & $2.5 \mathrm{Y} 5 / 2$ & Com., Dist. & Many, Prom. \\
\hline $\mathrm{Cg}$ & $150+$ & FSL & $5 Y 5 / 1$ & Com., Fnt. & Com., Prom. \\
\hline
\end{tabular}

GS; Upland Zone

\begin{tabular}{c|ccccc}
\hline & $\begin{array}{c}\text { Lower } \\
\text { Depth } \\
(\mathrm{cm})\end{array}$ & $\begin{array}{c}\text { Texture } \\
\text { Class }\end{array}$ & Color & Depletions & Concentrations \\
\hline Oe & 8 & Hemic & 10YR 2/2 & - & - \\
AE & 15 & SL & 10YR 2/1 & - & - \\
Bw1 & 34 & SL & 10YR 4/3 & - & - \\
Bw2 & 61 & SL & $2.5 Y 5 / 3$ & - & - \\
BCg & 81 & SL & 2.5Y 5/2 & Com., Dist. & Com., Dist. \\
Cg & $130+$ & FSL & 5Y 6/1 & Many, Fnt. & Many, Prom.
\end{tabular}


APPENDIX 6. An analysis of the absolute percent cover of dominant vegetation in each vernal pool.

$\triangle$ Tree
$\bigcirc$ Sapling/Shrub
$\square$ Herb
$\diamond$ Woody Vine
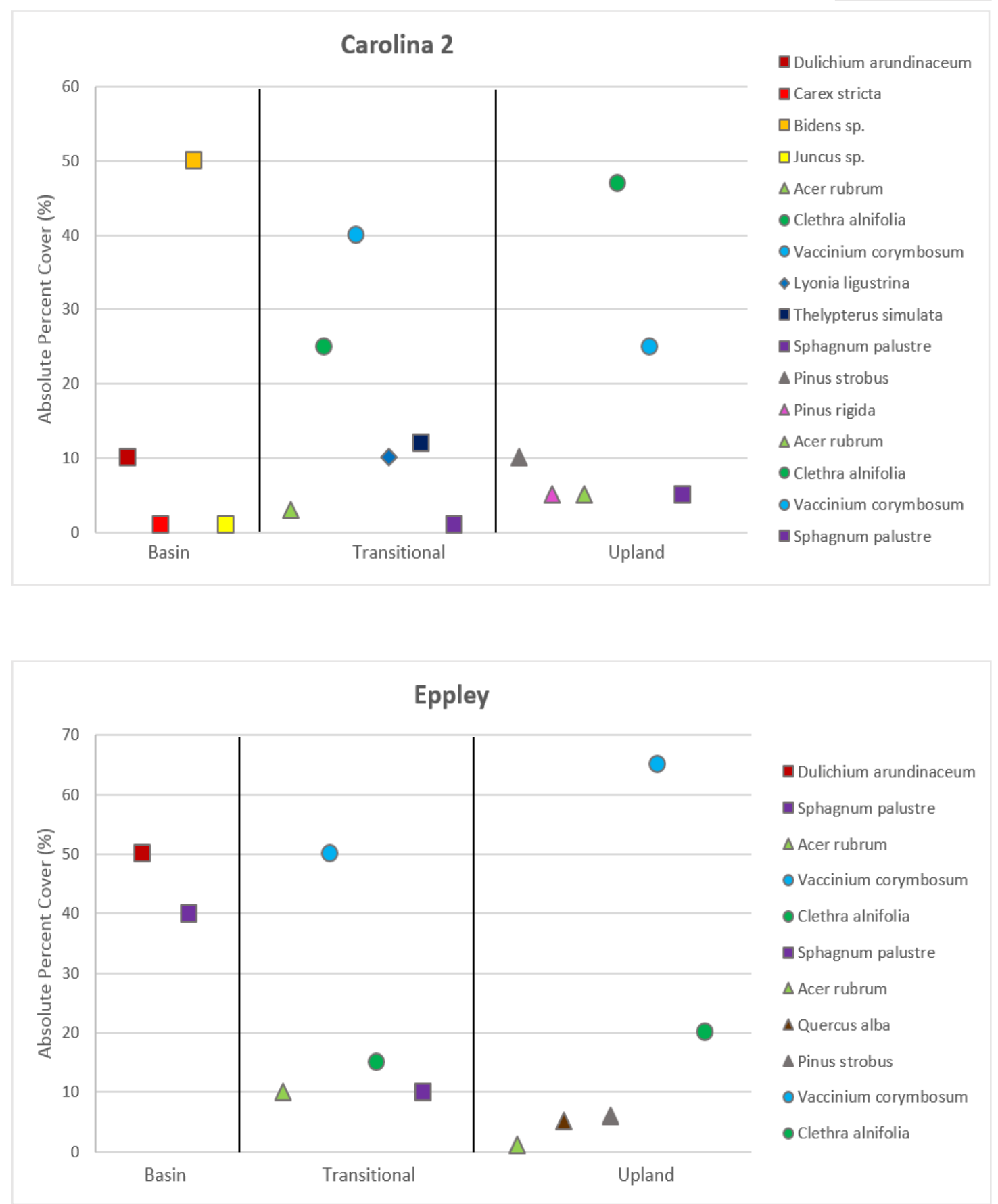
APPENDIX 7. Soil morphological descriptions of $50 \mathrm{~cm}$ cores.

CAR 2; Basin Zone (1A)

\begin{tabular}{c|ccccc}
\hline & $\begin{array}{c}\text { Lower } \\
\text { Depth } \\
(\mathrm{cm})\end{array}$ & $\begin{array}{c}\text { Texture } \\
\text { Class }\end{array}$ & Color & Depletions & Concentrations \\
\hline Horizon & 6 & Sapric & 10YR 2/2 & - & - \\
$\mathrm{A}$ & 15 & SL & 10YR 2/1 & Com., Dist. & Few, Fnt. \\
$\mathrm{Bg}$ & 23 & COSL & 10YR 4/2 & Com., Dist. & Few, Fnt. \\
$\mathrm{Ab}$ & 19 & COSL & 10YR 2/1 & Com., Dist. & Few, Fnt. \\
B'g & 40 & COSL & 10YR 4/2 & Com., Dist. & Few, Fnt. \\
A'b & $50+$ & SIL & 10YR 2/1 & Com., Dist. & Few, Fnt.
\end{tabular}

CAR 2; Basin Zone (1B)

\begin{tabular}{c|ccccc}
\hline & $\begin{array}{c}\text { Lower } \\
\text { Depth } \\
(\mathrm{cm})\end{array}$ & $\begin{array}{c}\text { Texture } \\
\text { Class }\end{array}$ & Color & Depletions & Concentrations \\
\hline Harizon & 6 & Sapric & 10 YR2/2 & - & - \\
$\mathrm{A}$ & 12 & SL & 10 YR2/1 & Com., Dist. & Few, Fnt. \\
$\mathrm{Bg} 1$ & 23 & COSL & $2.5 Y 4 / 2$ & Com., Dist. & Few, Fnt. \\
Bg2 & 33 & COSL & $2.5 Y 4 / 1$ & Many, Dist. & Few, Fnt. \\
Ab1 & 43 & SIL & 10 YR 2/1 & Few, Dist. & Few, Fnt. \\
Ab2 & $50+$ & SL & $10 Y R 3 / 1$ & Com., Dist. & Few, Fnt.
\end{tabular}

CAR 2; Transitional Zone (2A)

\begin{tabular}{c|ccccc}
\hline Horizon & $\begin{array}{c}\text { Lower } \\
\text { Depth } \\
(\mathrm{cm})\end{array}$ & $\begin{array}{c}\text { Texture } \\
\text { Class }\end{array}$ & Color & Depletions & Concentrations \\
\hline Oe & 8 & Hemic & 10YR 2/2 & - & - \\
Ap & 23 & SL & 10YR 2/1 & - & - \\
Bhs1 & 41 & GR SL & $7.5 Y R 3 / 1$ & - & Few, Fnt. \\
Bhs2 & $50+$ & VGR SL & $7.5 Y R 3 / 1$ & Few, Dist. & Com., Fnt.
\end{tabular}


CAR 2; Transitional Zone (2B)

\begin{tabular}{c|ccccc}
\hline & $\begin{array}{c}\text { Lower } \\
\text { Depth } \\
(\mathrm{cm})\end{array}$ & $\begin{array}{c}\text { Texture } \\
\text { Class }\end{array}$ & Color & Depletions & Concentrations \\
\hline Oe & 9 & Hemic & 10YR 2/2 & - & - \\
Ap & 28 & SL & 10 YR 2/1 & - & - \\
Bhs1 & 44 & COSL & $7.5 Y R 3 / 2$ & Few, Dist. & Few, Fnt. \\
Bhs2 & $50+$ & SL & $7.5 Y R 3 / 1$ & - & Few, Fnt.
\end{tabular}

CAR 2; Upland Zone (3A)

\begin{tabular}{c|ccccc}
\hline & $\begin{array}{c}\text { Lower } \\
\text { Depth } \\
(\mathrm{cm})\end{array}$ & $\begin{array}{c}\text { Texture } \\
\text { Class }\end{array}$ & Color & Depletions & Concentrations \\
\hline Oe & 8 & Hemic & 10YR 2/2 & - & - \\
$\mathrm{AE}$ & 16 & SL & 10YR 3/2 & - & - \\
$\mathrm{Bw} 1$ & 29 & SL & 10YR 3/4 & - & - \\
$\mathrm{Bw} 2$ & 40 & COSL & 10YR 4/3 & Few, Dist. & Com., Dist. \\
$\mathrm{Ab}$ & 48 & COSL & $2.5 \mathrm{Y} 2.5 / 1$ & Com., Prom. & - \\
$\mathrm{Cgb}$ & $50+$ & COSL & 2.5 Y 5/1 & Com., Fnt. & -
\end{tabular}

CAR 2; Upland Zone (3B)

\begin{tabular}{c|ccccc}
\hline & $\begin{array}{c}\text { Lower } \\
\text { Depth } \\
\text { Horizon }\end{array}$ & $\begin{array}{c}\text { Texture } \\
\text { Class }\end{array}$ & Color & Depletions & Concentrations \\
\hline $\mathrm{Oe}$ & 4 & Hemic & 10YR 3/1 & - & - \\
$\mathrm{AE}$ & 11 & SL & 10YR 2/1 & - & - \\
$\mathrm{Bw} 1$ & 25 & COSL & 10YR 3/3 & - & - \\
$\mathrm{Bw} 2$ & 42 & COSL & 10YR 4/3 & Few, Fnt. & Com., Prom. \\
$\mathrm{Ab}$ & $50+$ & SL & 2.5 Y 2.5/1 & Com., Prom. & -
\end{tabular}

CAR 3; Basin Zone (1A)

\begin{tabular}{|c|c|c|c|c|c|}
\hline Horizon & $\begin{array}{l}\text { Lower } \\
\text { Depth } \\
\text { (cm) }\end{array}$ & $\begin{array}{c}\text { Texture } \\
\text { Class }\end{array}$ & Color & Depletions & Concentrations \\
\hline Ap1 & 16 & SIL & 10YR 2/1 & Few, Dist. & Few, Dist. \\
\hline Ap2 & 28 & SL & 10YR 2/1 & Many, Dist. & Few, Dist. \\
\hline Bhs1 & 37 & COSL & $7.5 \mathrm{YR} 3 / 2$ & - & Com., Dist. \\
\hline Bhs2 & $50+$ & COSL & $7.5 \mathrm{YR} 4 / 3$ & - & Com., Fnt. \\
\hline
\end{tabular}


CAR 3; Basin Zone (1B)

\begin{tabular}{c|ccccc}
\hline & $\begin{array}{c}\text { Lower } \\
\text { Depth } \\
\text { Horizon }\end{array}$ & $\begin{array}{c}\text { Texture } \\
\text { Class }\end{array}$ & Color & Depletions & Concentrations \\
\hline Oa & 3 & Sapric & 10YR 2/1 & - & - \\
AE & 7 & SL & 10YR 2/1 & - & - \\
Bhs1 & 23 & SL & 10YR 3/1 & - & - \\
Bhs2 & 30 & COSL & 10YR 3/1 & - & Few, Fnt. \\
Bhs3 & $50+$ & COSL & $7.5 Y R 4 / 2$ & Com., Dist. & Com., Dist.
\end{tabular}

CAR 3; Transitional Zone (2A)

\begin{tabular}{c|ccccc}
\hline & $\begin{array}{c}\text { Lower } \\
\text { Depth } \\
(\mathrm{cm})\end{array}$ & $\begin{array}{c}\text { Texture } \\
\text { Class }\end{array}$ & Color & Depletions & Concentrations \\
\hline Oe & 5 & Hemic & 10YR 2/2 & - & - \\
Ap & 20 & SL & 10 YR 2/1 & - & - \\
Bhs1 & 34 & SL & $7.5 Y R ~ 3 / 2$ & Few, Dist. & Few, Fnt. \\
Bhs2 & $50+$ & GR SL & 7.5 YR 4/3 & Com., Dist. & Many, Dist.
\end{tabular}

CAR 3; Transitional Zone (2B)

\begin{tabular}{c|ccccc}
\hline & $\begin{array}{c}\text { Lower } \\
\text { Depth } \\
(\mathrm{cm})\end{array}$ & $\begin{array}{c}\text { Texture } \\
\text { Class }\end{array}$ & Color & Depletions & Concentrations \\
Horizon & 8 & Hemic & 10YR 2/2 & - & - \\
Oe & 19 & SL & 10YR 2/1 & - & - \\
Ap & 27 & SL & $7.5 Y R ~ 3 / 2$ & - & - \\
Bhs1 & 41 & SL & $5 Y R 3 / 2$ & Few, Prom. & Com., Fnt. \\
Bhs2 & $50+$ & FSL & 2.5Y 6/3 & Com., Dist. & Com., Prom. \\
C & $50+$ & & & &
\end{tabular}

CAR 3; Upland Zone (3A)

\begin{tabular}{|c|c|c|c|c|c|}
\hline Horizon & $\begin{array}{c}\text { Lower } \\
\text { Depth } \\
(\mathrm{cm})\end{array}$ & $\begin{array}{c}\text { Texture } \\
\text { Class }\end{array}$ & Color & Depletions & Concentrations \\
\hline $\mathrm{Oe}$ & 5 & Hemic & $10 Y R$ 2/2 & - & - \\
\hline A & 12 & SL & 10YR 3/1 & - & - \\
\hline BA & 25 & SL & $10 Y R 3 / 3$ & - & - \\
\hline Bw1 & 40 & GR SL & $10 Y R$ 4/4 & - & - \\
\hline Bw2 & 47 & GR SL & $10 Y R \quad 4 / 3$ & - & - \\
\hline Bw3 & $50+$ & GR SL & $10 Y R$ 4/6 & - & - \\
\hline
\end{tabular}


CAR 3; Upland Zone (3B)

\begin{tabular}{c|ccccc}
\hline & $\begin{array}{c}\text { Lower } \\
\text { Depth } \\
\text { Horizon }\end{array}$ & $\begin{array}{c}\text { Texture } \\
\text { Class }\end{array}$ & Color & Depletions & Concentrations \\
\hline Oe & 4 & Hemic & 10YR 2/2 & - & - \\
A & 10 & SL & 10YR 3/1 & - & - \\
BA & 19 & SL & 10YR 3/3 & - & - \\
Bw1 & 33 & GR SL & 10YR 4/4 & - & - \\
Bw2 & 47 & GR SL & 10YR 5/4 & - & - \\
Bw3 & $50+$ & GR SL & 10YR 4/3 & - & -
\end{tabular}

EP; Basin Zone (1A)

\begin{tabular}{c|ccccc}
\hline & $\begin{array}{c}\text { Lower } \\
\text { Depth } \\
\text { Horizon }\end{array}$ & $\begin{array}{c}\text { Texture } \\
\text { Class }\end{array}$ & Color & Depletions & Concentrations \\
\hline Oe & 9 & Hemic & 10YR 3/1 & - & - \\
Oa1 & 15 & Sapric & 10YR 3/2 & - & - \\
Oa2 & 30 & Sapric & 10YR 2/1 & - & - \\
Oa3 & $42+$ & Sapric & 10YR 2/2 & - & -
\end{tabular}

EP; Basin Zone (1B)

\begin{tabular}{c|ccccc}
\hline & $\begin{array}{c}\text { Lower } \\
\text { Depth } \\
\text { Horizon }\end{array}$ & $\begin{array}{c}\text { Texture } \\
\text { Class }\end{array}$ & Color & Depletions & Concentrations \\
\hline Oe & 8 & Hemic & 10YR 3/2 & - & - \\
Oa1 & 14 & Sapric & 10YR 3/3 & - & - \\
Oa2 & 27 & Sapric & 10YR 2/1 & - & - \\
Oa3 & $43+$ & Sapric & 10YR 2/2 & - & -
\end{tabular}

EP; Transitional Zone (2A)

\begin{tabular}{c|ccccc}
\hline & $\begin{array}{c}\text { Lower } \\
\text { Depth } \\
\text { Horizon }\end{array}$ & $\begin{array}{c}\text { Texture } \\
\text { Class }\end{array}$ & Color & Depletions & Concentrations \\
\hline Oi & 7 & Fibric & 10YR 2/2 & - & - \\
AE & 12 & GR COSL & 10YR 4/1 & - & - \\
Bw1 & 22 & GR COSL & 10YR 4/4 & - & Com., Dist. \\
Bw2 & 38 & GR COLS & 2.5Y 5/4 & Com., Dist. & Com., Dist. \\
Ab & $50+$ & SIL & 10YR 2/1 & Few, Fnt. & Few, Dist.
\end{tabular}


EP; Transitional Zone (2B)

\begin{tabular}{c|ccccc}
\hline & $\begin{array}{c}\text { Lower } \\
\text { Depth } \\
(\mathrm{cm})\end{array}$ & $\begin{array}{c}\text { Texture } \\
\text { Class }\end{array}$ & Color & Depletions & Concentrations \\
\hline Horizon & 6 & Fibric & 10YR 2/2 & - & - \\
AE & 10 & SL & 10YR 4/1 & - & - \\
Bw1 & 17 & SL & 10YR 3/2 & - & - \\
Bw2 & 24 & COSL & 10YR 4/3 & Com., Dist. & Com., Dist. \\
Ab & 48 & SIL & 10YR 2/1 & Few, Fnt. & Few, Dist. \\
Cgb & $50+$ & COS & $2.5 Y 4 / 2$ & Com., Fnt. & Few, Fnt.
\end{tabular}

EP; Upland Zone (3A)

\begin{tabular}{|c|c|c|c|c|c|}
\hline Horizon & $\begin{array}{l}\text { Lower } \\
\text { Depth } \\
\text { (cm) }\end{array}$ & $\begin{array}{l}\text { Texture } \\
\text { Class }\end{array}$ & Color & Depletions & Concentrations \\
\hline $\mathrm{Oe}$ & 4 & Hemic & $10 \mathrm{YR} 2 / 2$ & 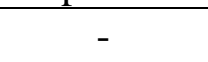 & 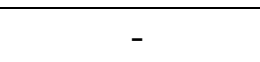 \\
\hline $\mathrm{AE}$ & 10 & COSL & $10 \mathrm{YR} 4 / 1$ & - & - \\
\hline Bw1 & 26 & COSL & $10 Y R 4 / 3$ & - & - \\
\hline Bw2 & 34 & LCOS & 10 YR $5 / 3$ & - & - \\
\hline Bw3 & $50+$ & COSL & $10 \mathrm{YR} 3 / 3$ & - & - \\
\hline
\end{tabular}

EP; Upland Zone (3B)

\begin{tabular}{c|ccccc}
\hline & $\begin{array}{c}\text { Lower } \\
\text { Depth } \\
\text { Horizon }\end{array}$ & $\begin{array}{c}\text { Texture } \\
\text { Class }\end{array}$ & Color & Depletions & Concentrations \\
\hline Oe & 2 & Hemic & 10YR 2/2 & - & - \\
AE & 12 & SL & 10YR 4/2 & - & - \\
Bw1 & 32 & GR SL & 10YR 4/3 & - & - \\
Bw2 & 42 & VGR SL & 10YR 5/3 & - & - \\
Bw3 & $50+$ & SL & 10YR 4/3 & - & -
\end{tabular}

GS; Basin Zone (1A)

\begin{tabular}{c|ccccc}
\hline & $\begin{array}{c}\text { Lower } \\
\text { Depth } \\
(\mathrm{cm})\end{array}$ & $\begin{array}{c}\text { Texture } \\
\text { Class }\end{array}$ & Color & Depletions & Concentrations \\
\hline Horizon & 9 & Hemic & 7.5 YR 3/2 & - & - \\
A & 19 & SIL & 10YR 2/1 & - & - \\
Bg & 29 & SIL & $2.5 Y 4 / 1$ & Many, Dist. & Few, Fnt. \\
Bhs & 43 & SL & 10YR 3/2 & Few, Fnt. & Com., Dist. \\
Bw & $50+$ & SL & 10YR 4/3 & Com., Dist. & Many, Dist.
\end{tabular}


GS; Basin Zone (1B)

\begin{tabular}{c|ccccc}
\hline & $\begin{array}{c}\text { Lower } \\
\text { Depth } \\
\text { Horizon }\end{array}$ & $\begin{array}{c}\text { Texture } \\
\text { Class }\end{array}$ & Color & Depletions & Concentrations \\
\hline Oe & 6 & Hemic & 7.5 YR 3/2 & - & - \\
$\mathrm{A}$ & 17 & SIL & 10 YR 3/1 & - & - \\
Bg & 28 & SIL & $2.5 Y 4 / 1$ & Many, Dist. & Few, Fnt. \\
Bhs & 40 & SL & 10 YR 3/2 & Com., Dist. & Com., Dist. \\
Bw & $50+$ & SL & $2.5 Y 4 / 3$ & Com., Dist. & Many, Prom.
\end{tabular}

GS; Transitional Zone (2A)

\begin{tabular}{c|ccccc}
\hline & $\begin{array}{c}\text { Lower } \\
\text { Depth } \\
(\mathrm{cm})\end{array}$ & $\begin{array}{c}\text { Texture } \\
\text { Class }\end{array}$ & Color & Depletions & Concentrations \\
\hline Horizon & 7 & Hemic & 7.5 YR 2.5/2 & - & - \\
A & 13 & SIL & 10 YR 2/1 & - & - \\
Bg & 23 & SL & $2.5 Y 4 / 1$ & Many, Fnt. & - \\
Bhs1 & 30 & SL & $7.5 Y R ~ 3 / 1$ & Few, Fnt. & Com., Dist. \\
Bhs2 & 47 & SL & $7.5 Y R ~ 3 / 3$ & Few, Fnt. & Com., Dist. \\
C & $50+$ & SL & $2.5 Y 5 / 4$ & Com., Fnt. & Com., Dist.
\end{tabular}

GS; Transitional Zone (2B)

\begin{tabular}{c|ccccc}
\hline & $\begin{array}{c}\text { Lower } \\
\text { Depth } \\
(\mathrm{cm})\end{array}$ & $\begin{array}{c}\text { Texture } \\
\text { Class }\end{array}$ & Color & Depletions & Concentrations \\
\hline Horizon & 3 & Hemic & 10YR 2/2 & - & - \\
$\mathrm{A}$ & 18 & SIL & 10YR 2/1 & - & - \\
$\mathrm{Bg}$ & 29 & SL & $2.5 Y$ 4/1 & Many, Fnt. & - \\
$\mathrm{Ab}$ & 40 & SL & 10YR 2/1 & - & - \\
Bhs1 & 48 & SL & 10YR 3/3 & Few, Fnt. & Com., Dist. \\
Bhs2 & $50+$ & SL & 10YR 4/3 & Few, Fnt. & Com., Dist.
\end{tabular}

GS; Upland Zone (3A)

\begin{tabular}{|c|c|c|c|c|c|}
\hline Horizon & $\begin{array}{c}\text { Lower } \\
\text { Depth } \\
(\mathrm{cm})\end{array}$ & $\begin{array}{c}\text { Texture } \\
\text { Class }\end{array}$ & Color & Depletions & Concentrations \\
\hline $\mathrm{Oe}$ & 7 & Hemic & 10YR 2/1 & - & - \\
\hline A & 18 & COSL & 10YR 3/1 & - & - \\
\hline Bw1 & 33 & SL & 10YR 3/4 & - & - \\
\hline Bw2 & $50+$ & SL & 10YR 4/3 & - & - \\
\hline
\end{tabular}


GS; Upland Zone (3B)

\begin{tabular}{c|ccccc}
\hline & $\begin{array}{c}\text { Lower } \\
\text { Depth } \\
\text { Horizon }\end{array}$ & $\begin{array}{c}\text { Texture } \\
\text { Class }\end{array}$ & Color & Depletions & Concentrations \\
\hline Oe & 6 & Hemic & 10YR 2/2 & - & - \\
A & 13 & SL & 10YR 2/1 & - & - \\
AB & 25 & COSL & 10YR 3/1 & - & - \\
Bw1 & 40 & SL & 10YR 4/3 & - & - \\
Bw2 & $50+$ & SL & 10YR 4/3 & - & -
\end{tabular}


APPENDIX 8. Soil data obtained from $50 \mathrm{~cm}$ cores (bulk density and LOI)

CAR 2

\begin{tabular}{c|ccc}
\hline $\begin{array}{c}\text { Zone and } \\
\text { Replicate }\end{array}$ & $\begin{array}{c}\text { Master } \\
\text { Horizon }\end{array}$ & $\begin{array}{c}\text { Bulk } \\
\text { Density } \\
\left(\mathrm{g} / \mathrm{cm}^{3}\right)\end{array}$ & $\begin{array}{c}\text { SOM } \\
(\%)\end{array}$ \\
\hline 1A & $\mathrm{O}$ & 0.06 & 47.9 \\
1B & $\mathrm{O}$ & 0.03 & 38.7 \\
1A & $\mathrm{A}$ & 1.15 & 2.8 \\
1B & $\mathrm{A}$ & 1.41 & 5.4 \\
1A & $\mathrm{B}$ & 1.64 & 3.1 \\
1B & $\mathrm{B}$ & 1.17 & 1.1 \\
1A & $\mathrm{Ab}$ & 0.99 & 5.1 \\
1B & $\mathrm{Ab}$ & 1.08 & 6.7 \\
2A & $\mathrm{O}$ & 0.03 & 77.0 \\
2B & $\mathrm{O}$ & 0.11 & 46.2 \\
2A & $\mathrm{A}$ & 0.68 & 5.4 \\
2B & $\mathrm{A}$ & 0.61 & 8.4 \\
2A & $\mathrm{B}$ & 1.32 & 3.0 \\
2B & $\mathrm{B}$ & 1.34 & 3.7 \\
3A & $\mathrm{O}$ & 0.09 & 57.4 \\
3B & $\mathrm{O}$ & 0.17 & 25.1 \\
3A & $\mathrm{AE}$ & 0.33 & 7.4 \\
3B & $\mathrm{AE}$ & 0.24 & 4.6 \\
3A & $\mathrm{B}$ & 1.15 & 3.3 \\
3B & $\mathrm{B}$ & 1.35 & 1.3 \\
3A & $\mathrm{Ab}$ & 1.26 & 5.2 \\
3B & $\mathrm{Ab}$ & 2.11 & 4.3 \\
3A & $\mathrm{C}$ & 2.42 & 2.1
\end{tabular}


CAR 3

\begin{tabular}{c|ccc}
\hline $\begin{array}{c}\text { Zone and } \\
\text { Replicate }\end{array}$ & $\begin{array}{c}\text { Master } \\
\text { Horizon }\end{array}$ & $\begin{array}{c}\text { Bulk } \\
\text { Density } \\
\left(\mathrm{g} / \mathrm{cm}^{3}\right)\end{array}$ & $\begin{array}{c}\text { SOM } \\
(\%)\end{array}$ \\
\hline 1B & O & 0.62 & 7.9 \\
1A & A & 0.95 & 3.3 \\
1B & AE & 0.74 & 3.3 \\
1A & B & 1.53 & 3.3 \\
1B & B & 1.27 & 1.0 \\
2A & O & 0.14 & 40.2 \\
2B & O & 0.07 & 34.0 \\
2A & A & 0.97 & 5.7 \\
2B & A & 1.07 & 7.0 \\
2A & B & 1.17 & 3.5 \\
2B & B & 1.12 & 4.9 \\
2B & C & 1.29 & 2.7 \\
3A & O & 0.22 & 26.4 \\
3B & O & 0.15 & 23.2 \\
3A & A & 0.69 & 7.5 \\
3B & A & 1.17 & 7.0 \\
3A & B & 1.09 & 2.8 \\
3B & B & 0.87 & 3.3
\end{tabular}

EP

\begin{tabular}{c|ccc}
\hline $\begin{array}{c}\text { Zone and } \\
\text { Replicate }\end{array}$ & $\begin{array}{c}\text { Master } \\
\text { Horizon }\end{array}$ & $\begin{array}{c}\text { Bulk } \\
\text { Density } \\
\left(\mathrm{g} / \mathrm{cm}^{3}\right)\end{array}$ & $\begin{array}{c}\text { SOM } \\
(\%)\end{array}$ \\
\hline 1A & Oa & 0.21 & 57.4 \\
1B & Oa & 1.10 & 25.8 \\
1A & Oe & 0.02 & 86.2 \\
1B & Oe & 0.00 & 89.6 \\
2A & O & 0.02 & 74.8 \\
2B & O & 0.08 & 76.0 \\
2A & AE & 0.72 & 4.1 \\
2A & $\mathrm{B}$ & 1.92 & 1.4 \\
2A & Ab & 1.03 & 8.8 \\
2A & $\mathrm{C}$ & 1.75 & 1.7 \\
3A & O & 0.11 & 26.1 \\
3B & O & 0.13 & 69.1 \\
3A & A & 0.36 & 6.4 \\
3B & A & 0.43 & 6.0 \\
3A & B & 1.50 & 1.1 \\
3B & B & 1.47 & 1.4 \\
& & & 105
\end{tabular}




\begin{tabular}{l|ccc}
\multicolumn{1}{l}{ GS } \\
\multicolumn{5}{l}{ Bulk } \\
Zone and & $\begin{array}{c}\text { Master } \\
\text { Replicate }\end{array}$ & $\begin{array}{c}\text { Density } \\
\left(\mathrm{g} / \mathrm{cm}^{3}\right)\end{array}$ & $\begin{array}{c}\text { SOM } \\
(\%)\end{array}$ \\
\hline 1A & O & 0.02 & 80.7 \\
1B & O & 0.02 & 67.8 \\
1A & A & 0.43 & 24.3 \\
1B & A & 0.26 & 25.2 \\
1A & B & 1.25 & 3.9 \\
1B & B & 1.33 & 4.2 \\
2A & O & 0.02 & 85.9 \\
2B & O & 0.16 & 47.9 \\
2A & A & 0.39 & 32.0 \\
2B & A & 0.42 & 12.7 \\
2A & B & 1.13 & 4.9 \\
2B & B & 1.42 & 2.7 \\
2B & Ab & 1.12 & 8.6 \\
2A & C & 2.65 & 2.1 \\
3A & O & 0.26 & 18.6 \\
3B & O & 0.27 & 31.1 \\
3A & A & 1.30 & 5.8 \\
3B & A & 0.81 & 5.6 \\
3A & B & 1.28 & 2.5 \\
3B & B & 1.61 & 1.4 \\
& & &
\end{tabular}




\section{BIBLIOGRAPHY}

Altor, A. E., and W. J. Mitsch. 2008. Methane and carbon dioxide dynamics in wetland mesocosms: effects of hydrology and soils. Ecological Applications 18: 1307-1320.

Amador, J. A., and E. J. Avizinis. 2013. Response of Nitrous Oxide Flux to Addition of Anecic Earthworms to an Agricultural Field. Open Journal of Soil Science 3: $100-106$

Andrews, J. A., K. G. Harrison, R. Matamala, and W. H. Schlesinger. 1999. Separation of root respiration from total soil respiration using carbon-13 labeling during free-air carbon dioxide enrichment (FACE). Soil Science Society of America Journal 63: 1429-1435.

ArchMiller, A. A., and L. J. Samuelson. 2016. Intra-annual variation of soil respiration across four heterogeneous longleaf pine forests in the southeastern United States. Forest Ecology and Management 359: 370-380.

August P. V. A., A. J. McCann, and C. L. Labash. 1995. Geographic information systems in Rhode Island. Natural Resource Facts Fact Sheet No. 95-1. University of Rhode Island, Kingston, RI, USA.

Austin, A. T., and P. M. Vitousek. 2000. Precipitation, decomposition and litter decomposability of Metrosideros polymorpha in native forests on Hawai'i. Journal of Ecology 88: 129-138.

Bernhard, A. 2012. The nitrogen cycle: Processes, players, and human impact. Nature Education Knowledge 3: 25.

Betts, R. A., C. D. Jones, J. R. Knight, R. F. Keeling, and J. J Kennedy. 2016. El Nino and a record $\mathrm{CO}_{2}$ rise. Nature Climate Change.

Bontti, E. E., J. P. Decant, S. M. Munson, M. A. Gathany, A. Przeszlowska, M. L. Haddix, and M. E. Harmon. 2009. Litter decomposition in grasslands of central North America (US Great Plains). Global Change Biology 15: 1356-1363.

Bridgham, S. D., J. P. Megonigal, J. K. Keller, N. B. Bliss, and C. Trettin. 2006. The carbon balance of North American wetlands. Wetlands 26: 889-916.

Brinson, M. M., A. E. Lugo, \& S. Brown. 1981. Primary productivity, decomposition and consumer activity in freshwater wetlands. Annual Review of Ecology and Systematics 12: 123-161. 
Brooks, R. T., and M. Hayashi. 2002. Depth-area-volume and hydroperiod relationships of ephemeral (vernal) forest pools in southern New England. Wetlands 22: 247-255.

Brooks, R. T. 2005. A review of basin morphology and pool hydrology of isolated ponded wetlands: implications for seasonal forest pools of the northeastern United States. Wetlands Ecology and Management 13: 335-348

Calhoun, A. J. K., and P. DeMaynadier. 2004. Forestry habitat management guidelines for vernal pool wildlife. MCA Technical Paper No. 6, Metropolitan Conservation Alliance, Wildlife Conservation Society, Bronx, New York.

Capps, K. A., M. A. Graça, A. C. Encalada, and A. S. Flecker. 2011. Leaf-litter decomposition across three flooding regimes in a seasonally flooded Amazonian watershed. Journal of Tropical Ecology 27: 205-210.

Capps, K. A., R. Rancatti, N. Tomczyk, T. B. Parr, A. J. K. Calhoun, and M. Hunter Jr. 2014. Biogeochemical hotspots in forested landscapes: the role of vernal pools in denitrification and organic matter processing. Ecosystems 17:14551468.

Chuersuwan, S., P. Suwanwaree, \& N. Chuersuwan. 2014. Estimating greenhouse gas fluxes from constructed wetlands used for water quality improvement. Songklanakarin Journal of Science \& Technology 36: 367-373.

Craft, C. B., and W. P. Casey. 2000. Sediment and nutrient accumulation in floodplain and depressional freshwater wetlands of Georgia, USA. Wetlands 20: 323-332.

Cutko, A., and T. J. Rawinski. 2008. Flora of northeastern vernal pools. Science and ' conservation of vernal pools in Northeastern North America. Wiley \& Sons Inc. New York, NY.

Dahlgren R. A. and F. C. Ugolini. 1989. Aluminum fractionation of soil solutions from unperturbed and tephra-treated Spodosols, Cascade Range, Washington, USA. Soil Sci. Soc. Am. J. 53: 559-566. Fahey T. and Yavitt J. 1988. Soil solution chemistry in lodgepole pine (Pinus contorta ssp. latifolia) ecosystems, southeastern Wyoming, USA. Biogeochemistry 6: 91-118.

Davidson, E. A., and I. A. Janssens. 2006. Temperature sensitivity of soil carbon decomposition and feedbacks to climate change. Nature 440: 165-173.

Davis, A. A. 2001. Carbon storage, variability, and flux in forest soils of southern New England. M.S. Thesis. Department of Natural Resources Science, University of Rhode Island, Kingston, RI. 
Davis, A. A., J. E. Compton, and M. H. Stolt. 2010. Soil respiration and ecosystem carbon stocks in New England forests with varying soil drainage. Northeastern Naturalist, 17: 437-454.

Diamond, H. J., T. R. Karl, M. A. Palecki, C. B. Baker, J. E. Bell, R. D. Leeper. 2013. U.S. Climate Reference Network after one decade of operations. Bulletin of the American Meteorological Society 94:485-498.

Douglas, C. L., and R. W. Rickman. 1992. Estimating crop residue decomposition from air temperature, initial nitrogen content, and residue placement. Soil Science Society of America Journal 56: 272-278.

D.V. D'Amore, C. L. Ping, P. A. Herendeen. 2015. Hydromorphic soil development in the coastal temperate rainforest of Alaska. Soil Science Society of America Journal 79: 698-709

ESRI, 2011. PC ARC/INFO, Version 10.3.1. Environmental Systems Research Institute, Redlands, CA, USA.

Fanning, D. S., and M. C. B. Fanning. 1989. Soil morphology, genesis and classification. John Wiley and Sons Inc.

Ford, E. C. 2014. Investigating problematic hydric soils derived from red-colored glacial till in the Hartford Rift Basin of Connecticut. Department of Natural Resources Science, University of Rhode Island, Kingston, RI.

Gorham, E. 1991. Northern peatlands: role in the carbon cycle and probable responses to climatic warming. Ecological Applications 1: 182-195.

Groffman, P. M., G. C. Hanson, E. Kiviat, \& G. Stevens. 1996. Variation in microbial biomass and activity in four different wetland types. Soil Science Society of America Journal 60: 622-629.

Grant, E. H. C. 2005. Correlates of vernal pool occurrence in the Massachusetts, USA landscape. Wetlands 25: 480-487.

Hanes, W. T. and L. P. Stromberg. 1998. Hydrology of the vernal pools on nonvolcanic soils in the Sacramento Valley, California. Pages 38-49 in: C.W. Witham, E. Bauder, D. Belk, W. Ferren, and R. Ornduff (Editors). Ecology, Conservation, and Management of Vernal Pool Ecosystems - Proceedings from a 1996 Conference. California Native Plant Society, Sacramento, CA.

Hobson, W. A., and R. A. Dahlgren. 1998. Soil forming processes in vernal pools of northern California, Chico area. Ecology, conservation, and management of vernal pool ecosystems: 24-37. 
Holgerson, M. A. 2015. Drivers of carbon dioxide and methane supersaturation in small, temporary ponds. Biogeochemistry 124: 305-318.

Homann, P. S., and D. F. Grigal. 1996. Below-ground organic carbon and decomposition potential in a field-forest glacial-outwash landscape. Biology and fertility of soils 23: 207-214.

Huntington, T. G. 1995. Carbon sequestration in an aggrading forest ecosystem in the southeastern USA. Soil Science Society of America Journal 59: 1459-1467.

Inglett, K. S., P. W. Inglett, K. R. Reddy, and T. Z. Osborne. 2012. Temperature sensitivity of greenhouse gas production in wetland soils of different vegetation. Biogeochemistry 108: 77-90.

IPCC. 2007. Climate change 2007: the physical science basis. Cambridge University Press, New York, NY.

Jackson, R., H. A. Mooney, and E. D. Schulze. 1997. A global budget for fine root biomass, surface area, and nutrient contents. Proceedings of the National Academy of Sciences 94: 7362-7366.

Jørgensen, C. J., S. Struwe, and B. Elberling. 2012. Temporal trends in N2O flux dynamics in a Danish wetland-effects of plant-mediated gas transport of $\mathrm{N}_{2} \mathrm{O}$ and $\mathrm{O}_{2}$ following changes in water level and soil mineral-N availability. Global Change Biology 18: 210-222.

Kagotani, Y., E. Hamabata, and T. Nakajima. 2001. Seasonal and spatial variations and the effects of clear-cutting in the methane absorption rates of a temperate forest soil. Nutrient Cycling in Agroecosystems 59: 169-175.

Kang, H., and C. Freeman. 2002. The influence of hydrochemistry on methane emissions from two contrasting northern wetlands. Water, Air, \& Soil Pollution 141: 263-272.

Kicklighter, D. W., J. M. Melillo, W. T. Peterjohn, E. B. Rastetter, A. D. McGuire, P. A. Steudler, and J. D. Aber. 1994. Aspects of spatial and temporal aggregation in estimating regional carbon dioxide fluxes from temperate forest soils. Journal of Geophysical Research: Atmospheres 99: 1303-1315.

Kristensen, E., S. I. Ahmed, and A. H. Devol. 1995. Aerobic and anaerobic decomposition of organic matter in marine sediment: which is fastest? Limnology and oceanography 40: 1430-1437.

Kuhn, M. 2015. Methane Dynamics in Vernal Pools. Doctoral Dissertation. Department of Environmental Science, Wheaton College, Norton, MA. 
Kuzyakov, Y. 2006. Sources of $\mathrm{CO}_{2}$ efflux from soil and review of partitioning methods. Soil Biology and Biochemistry 38: 425-448.

Larson, P. and C. Runyan. September, 2009. Evaluation of a Capacitance Water Level Recorder and Calibration Methods in an Urban Environment. UMBC/CUERE Technical Memo 2009/003. Universtiy of Maryland, Baltimore County, Center for Urban Environmental Research and Education, Baltimore, MD.

Leibowitz, S.G. 2003. Isolated wetlands and their functions: an ecological perspective. Wetlands 23:517-531.

MacLean, D. A., and R. W. Wein. 1978. Weight loss and nutrient changes in decomposing litter and forest floor material in New Brunswick forest stands. Canadian Journal of Botany 56: 2730-2749.

Marti, P. B. December, 2016. Standard Operating Procedure for Manual Well-Depth and Depth-to-Water Measurements. EAP052, Version 1.2. Washington State Department of Ecology, Environmental Assessment Program, Lacey, WA.

Mausbach, M. J. and Richardson, J. L., Biogeochemical processes in hydric soil formation, Current Topics in Wetland Biogeochemistry 1: 68-127, 1994.

McClain, M. E., E. W. Boyer, C. L. Dent, S. E. Gergel, N. B. Grimm, P. M. Groffman, and W. H. McDowell. 2003. Biogeochemical hot spots and hot moments at the interface of terrestrial and aquatic ecosystems. Ecosystems 6: 301-312.

McGroddy, M. E., T. Daufresne, and L. O. Hedin. 2004. Scaling of C: N: P stoichiometry in forests worldwide: Implications of terrestrial redfield-type ratios. Ecology 85: 2390-2401.

Megonigal, J. P., S. P. Faulkner, and W. H. Patrick. 1996. The microbial activity season in southeastern hydric soils. Soil Science Society of America Journal 60:1263-1266.

Mitsch, W. J., B. Bernal, A. M. Nahlik, Ü. Mander, L. Zhang, C. J. Anderson, and H. Brix. 2012. Wetlands, carbon, and climate change. Landscape Ecology 28: 583-597.

Moore, T. R., J. A. Trofymow, B. Taylor, C. Prescott, C. Camire, L. Duschene, J. Fyles, L. Kozak, M. Kranabetter, I. Morrison, M. Siltanen, S. Smith, B. Titus, S. Vissier, R. Wein, and S. Zoltai. 1999. Litter decomposition rates in Canadian forests. Global Change Biology 5: 75-82. 
Moseman-Valtierra, S., R. Gonzalez, K. D. Kroeger, J. Tang, W. C. Chao, J. Crusius, J. Bratton, A. Green, and J. Shelton, 2011. Short-term nitrogen additions can shift a coastal wetland from a sink to a source of $\mathrm{N}_{2} \mathrm{O}$. Atmospheric Environment. 45: 4390-4397.

National Technical Committee for Hydric Soils. 2007. The Hydric Soil Technical Standard (Hydric Soil Technical Note 11). Retrieved from: http://www.nrcs.usda.gov/Internet/FSE_DOCUMENTS/nrcs142p2_051608.pd f. Accessed 2/15/17.

Nelson, E. W., and L. E. Sommers. 1996. Total Carbon, Organic Carbon, and Organic Matter. Methods of soil analysis. pp. 961-1010 in Sparks, D. L. et al., (eds.) Part 3-Chemical methods. SSSA Book Series No. 5. Soil Science Society of America, Madison, WI.

O'Lear, H. A., T. R. Seastedt, J. M. Briggs, J. M. Blair, and R. A. Ramundo. 1996. Fire and topographic effects on decomposition rates and $\mathrm{N}$ dynamics of buried wood in tallgrass prairie. Soil Biology and Biochemistry 28: 323-329.

Oregon State University Agricultural Experiment Station. 2017. Online Phenology and Degree-day Models for agricultural pest management decision making in the US. Retrieved from: http://uspest.org/cgi-bin/ddmodel.us. Accessed 27 February 2017.

Rabenhorst, M. C. July, 2014. How to construct a well casing to hold Odyssey capacitance water level logger using standard PVC fittings. University of Maryland, Department of Environmental Sciences and Technology, College Park, MD.

Rains, M. C., G. E. Fogg, T. Harter, R. A. Dahlgren, and R. J. Williamson. 2006. The Role of Perched Aquifers in Hydrological Connectivity and Biogeochemical Processes in Vernal Pool Landscapes, Central Valley, California. Hydrological Processes 20:1157-1175.

Raich, J. W., and W. H. Schlesinger. 1992. The global carbon dioxide flux in soil respiration and its relationship to vegetation and climate. Tellus B 44: 81-99.

Raich, J. W., and C. S. Potter. 1995. Global patterns of carbon dioxide emissions from soils. Global Biogeochemical Cycles 9: 23-36.

Rector, D. D. 1981. Soil survey of Rhode Island. USDA Soil Conserv. Serv. In cooperation with the Rhode Island Agric. Exp. Stn., Washington, DC.

Reth, S., M. Reichstein, and E. Falge. 2005. The effect of soil water content, soil temperature, soil $\mathrm{pH}$-value and the root mass on soil $\mathrm{CO}_{2}$ efflux-A modified model. Plant and Soil 268: 21-33. 
Rheinhardt, R., G. Hollands, A. Calhoun, and P. DeMaynadier. 2007. Classification of vernal pools: geomorphic setting and distribution. Science and conservation of vernal pools in Northeastern North America, 11-29.

Ricker, M. C. 2010. Effects of Land Use on Riparian Soils. Department of Natural Resources Science, University of Rhode Island, Kingston, RI.

Ricker, M. C., M. H. Stolt, \& M. S. Zavada. 2014. Comparison of soil organic carbon dynamics in forested riparian wetlands and adjacent uplands. Soil Science Society of America Journal 78: 1817-1827.

RIGIS. 2002. 1939 Digital Aerial Photography. Rhode Island Geographic Information System Data Distribution System. Environmental Data Center, University of Rhode Island, Kingston, Rhode Island. Retrieved from: http://www.edc.uri.edu/rigis. Accessed 16 February 2015.

RIGIS. 2011. Spring 2011 Rhode Island Statewide LiDAR Data. Rhode Island Geographic Information System Data Distribution System. Environmental Data Center, University of Rhode Island, Kingston, Rhode Island. Retrieved from: http://www.edc.uri.edu/rigis. Accessed 16 February 2015.

RIGIS. 2014. Soils; soils14. Rhode Island Geographic Information System (RIGIS) Data Distribution System, Environmental Data Center, University of Rhode Island, Kingston, Rhode Island. Retrieved from: http://www.edc.uri.edu/rigis. Accessed 11 February 2015.

Schlentner, R. E., \& K. V. Cleve. 1985. Relationships between $\mathrm{CO}_{2}$ evolution from soil, substrate temperature, and substrate moisture in four mature forest types in interior Alaska. Canadian Journal of Forest Research 15: 97-106.

Schoeneberger, P. J., D. A. Wysocki, E. C. Benham, and W. D. Broderson. 2002. Field book for describing and sampling soils, Version 2.0. Natural Resources Conservation Service, National Soil Survey Center, Lincoln, NE.

Segers, R. 1998. Methane production and methane consumption: a review of processes underlying wetland methane fluxes. Biogeochemistry 41: 23-51.

Skidds, D. E., and F. C. Golet. 2005. Estimating hydroperiod suitability for breeding amphibians in southern Rhode Island seasonal forest ponds. Wetlands Ecology and Management 13:349-366.

Skidds, D. E. 2003. Potential Predictors of Hydroperiod in Southern Rhode Island Seasonal Ponds. Department of Natural Resources Science, University of Rhode Island, Kingston, RI. 
Smith, R. D., A. Ammann, C. Bartoldus, and M. M. Brinson. 1995. An approach for assessing wetland functions using hydrogeomorphic classification, reference wetlands, and functionalindices. Technical report WRP-DE-9, U.S. Army Engineer Waterways Experiment Station, Vicksburg, MS.

Stewart, R. E., \& Kantrud, H. A. 1971. Classification of natural ponds and lakes in the glaciated prairie region (No. 92). US Fish and Wildlife Service, Bureau of Sport Fisheries and Wildlife.

Stolt, M. H., Rabenhorst, M. C., Ghabbour, E. A., and G. Davies. 2016. Soil Color and US Northeast Aquods. Soil Science Society of America Journal, 80: 965-972.

Tiner, R. W. 2003. Geographically isolated wetlands of the United States. Wetlands 23: 494-516.

U.S. Army Corps of Engineers. 2012. Regional Supplement to the Corps of Engineers Wetland Delineation Manual: Northcentral and Northeast Region (Version 2.0), ERDC/EL TR-12-1, U.S. Army Engineer Research and Development Center, Vicksburg, MS.

USDA-NRCS. 2005. RI - County level climate data. Retrieved from: https://efotg.sc.egov.usda.gov/treemenuFS.aspx. Accessed 10 October 2016.

USDA-NRCS. 2011. Carbon to Nitrogen Ratios in Cropping Systems. Retrieved from: soils.usda.gov/sqi. Accessed 20 January 2017.

USDA-NRCS. 2016. Field Indicators of Hydric Soils in the United States, Version 8.0. L.M. Vasilas, G.W. Hurt, and C.V. Noble (eds.). USDA-NRCS, in cooperation with the National Technical Committee for Hydric Soils.

Wade, T., and R. Fay. 1989. Decomposition and the annual flux of detritus from fallen timber in tropical mangrove forests. In Proceedings of the Royal Society B: Biological Sciences 227: 227-247.

Waggoner, A. 2016. Effects of residual waste material as agricultural soil amendments on soil greenhouse gas fluxes. M.S. Thesis. Department of Natural Resources Science, University of Rhode Island, Kingston, RI.

Whiting, G. J., and J. P. Chanton. 2001. Greenhouse carbon balance of wetlands: methane emission versus carbon sequestration. Tellus B, 53: 521-528.

Witham, C. W., E. T. Bauder, D. Belk, W. R. Ferren Jr., and R. Ornduff. (Editors). Ecology, Conservation, and Management of Vernal Pool Ecosystems Proceedings from a 1996 Conference. Pages 56-70. California Native Plant Society, Sacramento, CA. 1998. 
Xiong, S., and C. Nilsson. 1997. Dynamics of leaf litter accumulation and its effects on riparian vegetation: a review. The Botanical Review 63: 240-264.

Zdruli, P., H. Eswaran, and J. Kimble. 1995. Organic carbon content and rates of sequestration in soils of Albania. Soil Science Society of America Journal 59: 1684-1687.

Zelder, P. H. 2003. Vernal pools and the concept of "isolated wetlands." Wetlands 23: 597-607. 